\title{
Variations on Mount Vernon: \\ Replicas of an Icon as Vehicles for American Memory
}

Lydia Mattice Brandt

B.A., New York University, 2004

A Thesis Presented to the Faculty of the Department of Architectural History

of the School of Architecture, The University of Virginia In Partial Fulfillment of the Requirement for the Degree

Master of Architectural History

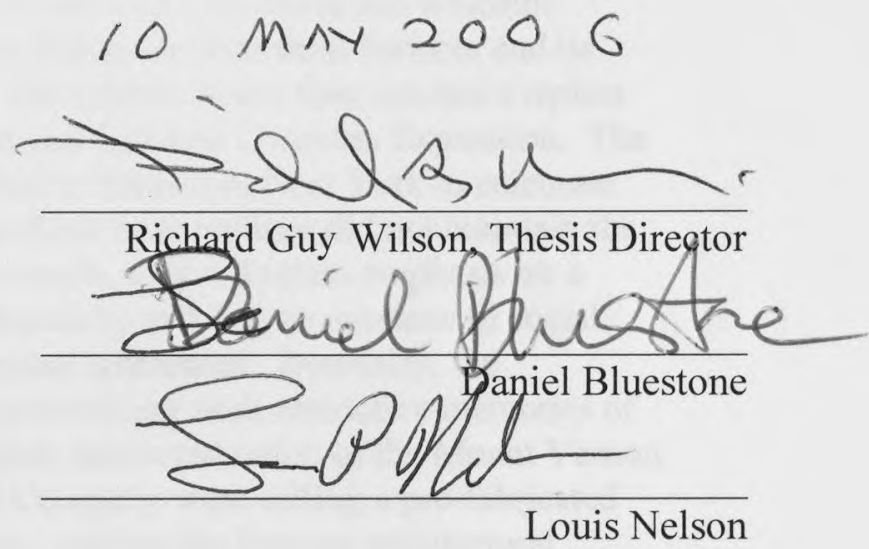


Lydia Mattice Brandt

Variations on Mount Vernon: Replicas of an Icon as Vehicles for American Memory

The replication of Mount Vernon - one of the icons of eighteenth-century American architecture - during the late nineteenth and early twentieth centuries served a range of purposes. Each version represented a different group's attempt to define their identity through their memory of George Washington, his home, and America's early history. These memories, therefore, were constructed in order to serve these identities and to provide a backdrop for the presentation of each replica. This thesis follows the ways in which Mount Vernon was appropriated by different collective memories - the regional, national, and Colonial Revival - and demonstrates that while Mount Vernon has been ever-present in American iconography, its meaning has never been fixed.

The Virginia Building at the 1893 World's Columbian Exposition in Chicago, Illinois, was the first in a series of reproductions of Mount Vernon at world's fairs or otherwise significant public events, and thus its conception and construction serves as a turning point in the history of Mount Vernon in American memory. This initial replica represented two narratives. One was regionally specific to the South and placed the building within the movement to memorialize the Lost Cause myth, whereas the other narrative was part of a longer national tradition of the memory of Washington and Mount Vernon that was emerging in American culture in the late nineteenth century through the Colonial Revival. Both narratives, despite their differences, were intent on depicting some version of an idealized domesticity of Washington and his iconic home; the domestic realm presented at the 1893 Virginia Building and the subsequent replicas presented an uncritical and uncontroversial view of antebellum American life. In addition, both narratives were central to the roles of late nineteenth and early twentieth century women as historic preservationists and keepers of public memory. This regional narrative persisted through the presentations of Southern and Virginian identity at the 1907 Jamestown Exposition and in the replica of Mount Vernon that was used as the Virginia Building at the 1915 Panama Pacific Exposition in San Francisco, Illinois. The replicas that followed World War I, however, became increasingly focused upon the national connotations of Mount Vernon as concepts and tropes of early American domesticity grew more commercialized and need for the Lost Cause myth faded. At the 1926 Sesqui-Centennial in Philadelphia, Pennsylvania, the Young Women's Christian Association erected a replica of Mount Vernon to serve as a cafeteria and welcome center, depending only upon the building's most distinct architectural features and its general concept of domesticity in their choice. The United States then erected a replica of Mount Vernon at the 1931 Paris International and Colonial Overseas Exposition. The next year, a version of Mount Vernon was erected in Brooklyn, New York to celebrate the bicentennial of Washington's birth. Though these later replicas did not maintain the allusions to Southern elitism and the Lost Cause myth, they did retain emphasis on a memory of an idealized Colonial American domesticity and had an overtone of social exclusiveness - they merely lost their direct regional references. Ironically, the reproductions of Mount Vernon that began by symbolizing such restrictive memories of Colonial American domesticity led to the complete democratization of the Mount Vernon domestic model. By 1932, Sears, Roebuck and Company were selling a pre-fabricated version of Mount Vernon through their catalogue, making the famous architectural symbol available to all Americans who could afford to purchase it. By the 1930s, a world war, national crises, and the fading of the living memory of the Civil War had laid aside sectional differences to allow Mount Vernon to be more egalitarian. 


\section{TABLE OF CONTENTS}

List of Illustrations

ii

Introduction

viii

I. George Washington, Mount Vernon, and the Memory of Colonial American Domesticity

II. The Regional Narrative: Mount Vernon as Monument to New South Ideology

III. Shift from Regional to National Identifications

Bibliography

73

Illustrations 


\section{ILLUSTRATIONS}

1. Land (west) elevation of Mount Vernon in Virginia. Photography by author.

2. Potomac River (east) elevation of Mount Vernon. Photograph by author.

3. Plan of Mount Vernon's first and second floors. Greenberg, Allan. George Washington, Architect. New York: Andreas Papadakius Publisher, 1999. Page 11.

4. Site Plan of Mount Vernon. Greenberg, Allan. George Washington, Architect. New York: Andreas Papadakius Publisher, 1999. Page 11. Modified by author.

5. The Virginia Building at the 1893 World's Columbian Exposition. The Dream City: A Portfolio of Photographic Views of the World's Columbian Exposition. St. Louis: N. D. Thompson Publishing Co., 1893.

6. The 1893 Virginia Building. Mount Vernon Ladies Associations Archives, Mount Vernon, Virginia.

7. The 1893 Virginia Building. Marling, Karal Ann. George Washington Slept Here: Colonial Revivals and American Culture, 1876-1986. Cambridge: Harvard University Press, 1988. Page 91.

8. The 1893 Virginia Building. Truman, Benjamin Cummings. History of the World's Fair: Being a Complete Description of the World's Columbian Exposition from Its Inception. Chicago: Monarch Book Co, 1893. Page 474.

9. Map of the Exposition grounds. The red dot represents the location of the Virginia Building. Lake Shore Public Schools. The Influence of the Chicago World's Fair.

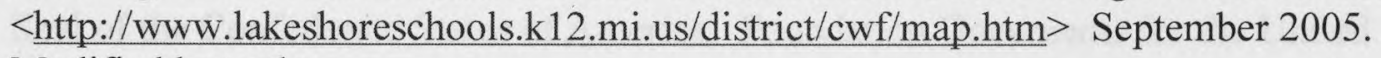
Modified by author.

10. John Trumbull, "The Resignation of George Washington," 1824-28, oil on canvas. Wills, Gary. Cincinnatus: George Washington and the Enlightenment: Images of Power in Early America. New York: Doubleday \& Co., 1984. Page 15.

11. "George Washington's Resignation," circa 1799, embroidered picture. Engraving published by Benjamin Davies based on a drawing by John James Barralet. CAMIO.

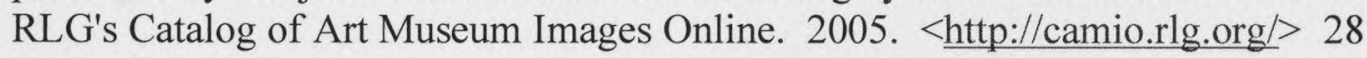
September 2005.

12. Junius Brutus Stearn, "Washington as a Farmer at Mount Vernon," 1851, oil on canvas. Rasmussen, William M. S. and Robert S. Tilton, eds. George Washington: The Man Behind the Myths. Charlottesville: University Press of Virginia, 1999. Page 192. 
13. Eastman Johnson, "Mount Vernon Kitchen," 1857, oil on canvas. Carbone, Teresa A. and Patricia Hills, eds. Eastman Johnson: Painting America. Brooklyn: Brooklyn Museum of Art, 1999. Page 124.

14. The ruined state of Mount Vernon in the 1850 s. Lee, Jean B. "Historical Memory, Sectional Strife, and the American Mecca, Mount Vernon, 1783-1853." Virginia Magazine of History and Biography 109, no. 3 (2001): 255-300. Page 268.

15. Ann Pamela Cunningham, founder of the Mount Vernon Ladies' Association. King, Grace Elizabeth. Mount Vernon on the Potomac: History of the Mount Vernon Ladies' Association of the Union. New York: The Macmillan Company, 1929. Frontispiece.

16. The Mount Vernon Ladies Association on the steps of Mount Vernon c. 1873, with Ann Pamela Cunningham seated and looking to the bust of Washington to her right. Lee, Jean B. "Historical Memory, Sectional Strife, and the American Mecca, Mount Vernon, 1783-1853." Virginia Magazine of History and Biography 109, no. 3 (2001): 255-300. Page 295.

17. 1876 Centennial "New England Log-House." Axelrod, Alan, ed. The Colonial Revival in America. New York: Norton, 1985. Page. 174.

18. "New England Log-House." Axelrod, Alan, ed. The Colonial Revival in America. New York: Norton, 1985. Page. 176.

19. Equestrian Statue of George Washington, begun in 1849 by Thomas Crawford and later finished by Randolph Rogers. Library of Virginia. Digitized Photograph Collection. <http://www.lva.lib.va.us/whatwehave/photo/index.htm> 17 April 2006.

20. Seal of the Confederate States of America. Foundation Documents for the United States and the Confederate States of America. 16 February 2006.

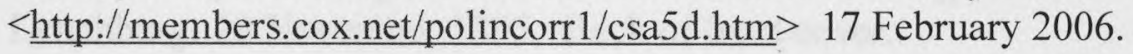

21. Lucy Preston Beale. "Lucy Preston Beale, ex -'64." The Hollins Alumnae Quarterly 3, no. 2 (July 1928): 19.

22. Edgerton Stewart Rogers. "Capt. Edgerton Rogers Dead." The Times (Richmond), 20 August 1901.

23. Randolph Rogers, Edgerton Stewart Rogers's father. Rogers, Millard F., Jr. Randolph Rogers: American Sculptor in Rome. Cambridge: The University of Massachusetts Press, 1971. Frontispiece. 
24. The Westmoreland Club, Richmond, Virginia. Westmoreland Club. The Constitution, By-Laws and House Rules of the Westmoreland Club of Richmond, VA. Richmond: The Bell Book and Stationery Co., 1909.

25. The Westmoreland Club flag. Westmoreland Club. The Constitution, By-Laws and House Rules of the Westmoreland Club of Richmond, VA. Richmond: The Bell Book and Stationery Co., 1909. Frontispiece.

26. Flag of the Confederacy. The University of Virginia. The Confederate Flag: Controversy and Culture.

$<\underline{\text { http://xroads.virginia.edu/ CLASS/am483_97/projects/sarratt/hope.html }>17}$ February 2006.

27. Maymont, Richmond, Virginia. Maymont Foundation. Maymont. Richmond: Maymont Foundation, 1992. Page 9.

28. Edgerton Stewart Rogers's second-place design for the Jefferson Davis Monument, 1896, Richmond, Virginia. "Adopt the Design." The Richmond Dispatch, 30 June 1896, p. 1.

29. Edgerton Stewart Rogers's drawings for the Virginia Building. Rogers, Edgerton S. "Details: Sketches by Edgerton S. Rogers, archt." Inland Architect and News Record 21 (April 1893): pl. fol. p. 42.

30. Relics shown in the Virginia Building. Truman, Benjamin Cummings. History of the World's Fair: Being a Complete Description of the World's Columbian Exposition from Its Inception. Chicago: Monarch Book Co, 1893. Page 475.

31. Royal Baking Powder Advertisement. The Virginian. Woman's Edition. Lynchburg: 28 November 1895 . Back of front cover.

32. Detail of Royal Baking Powder Advertisement. The Virginian. Woman's Edition. Lynchburg: 28 November 1895 . Back of front cover.

33. The United Daughters of the Confederacy Building at the 1907 Jamestown TerCentennial Exposition, a copy of Jefferson Davis's Mississippi home of Beauvoir. Keiley, Charles R., ed. The Official Blue Book of the Jamestown Ter-centennial Exposition, A. D. 1907. Norfolk: The Colonial Publishing Company, 1909. Page 386.

34. The Virginia Building at the 1907 Jamestown Exposition. The Online Archive of California. 2005. <http://www.oac.cdlib.org/> December 2005.

35. State Buildings at the 1907 Jamestown Exposition. Keiley, Charles R., ed. The Official Blue Book of the Jamestown Ter-centennial Exposition, A. D. 1907. Norfolk: The Colonial Publishing Company, 1909. Page 24. 
36. Interior of the Virginia Building at the 1907 Jamestown Exposition. The Online Archive of California. 2005. <http://www.oac.cdlib.org/> December 2005.

37. Interior of the 1907 Virginia Building. Hayes, ENS Mark, ed. An Illustrated History of the Jamestown Exposition. Norfolk: Hampton Roads Naval Museum.

38. Virginia Building at the 1915 Panama-Pacific International Exposition in San Francisco, California. San Francisco Public Library. San Francisco Historical Photograph Collection. 2004. <http://sfpl.lib.ca.us/> 16 February 2006.

39. 1915 Virginia Building. Berkeley Digital Library Sunsite. California Heritage Collection. 15 November 2004. <http://sunsite.berkeley.edu/CalHeritage/> 16 February 2006.

40. Map of the 1915 Panama-Pacific Exposition, the red circle indicating the location of the Virginia Building. Macomber, Ben. The Jewel City: Its Planning and Achievement; Its Architecture, Sculpture, Symbolism, and Music; Its Gardens, Palaces and Exhibits. San Francisco: John H. Williams, 1915. Pages 30-31. Modified by author.

41. Charles K. Bryant. Tunis, A. B., ed. Press Reference Book of Prominent Virginians. Richmond: Virginia Newspaper Writers Association, 1916. Page 35.

42. Charles K. Bryant's drawings of Mount Vernon for the 1915 Virginia Building. Bryant, Charles K. Measured Architectural Drawings of Mount Vernon. Mount Vernon Ladies' Association Archives, Mount Vernon, Virginia.

43. High Street at the 1926 Philadelphia Sesqui-Centennial. Cardinell, John D. A Pictorial Record of the Sesqui-Centennial International Exposition, Philadelphia, Pennsylvania, June $1^{\text {st }}$-December $1^{\text {st }}$ Nineteen Hundred Twenty Six, Commemorating the One Hundred and Fiftieth Anniversary of the Declaration of Independence of the United States. Philadelphia: John D. Cardinell, 1926.

44. High Street. Austin, E. L. and Odell Hauser. The Sesqui-Centennial International Exposition. Philadelphia: Current Publications, Inc., 1929. Page 165.

45. Young Women's Christian Association cafeteria at the 1926 Sesqui-Centennial in Philadelphia. Austin, E. L. and Odell Hauser. The Sesqui-Centennial International Exposition. Philadelphia: Current Publications, Inc., 1929. Page 180.

46. YWCA cafeteria. Cardinell, John D. A Pictorial Record of the Sesqui-Centennial International Exposition, Philadelphia, Pennsylvania, June $1^{\text {st }}$-December $1^{\text {st }}$ Nineteen Hundred Twenty Six, Commemorating the One Hundred and Fiftieth Anniversary of the Declaration of Independence of the United States. Philadelphia: John D. Cardinell, 1926. 
47. The United States Building at the 1931 Paris International and Colonial Overseas Exposition. Rydell, Robert W. World of Fairs: The Century-of-Progress Expositions. Chicago: The University of Chicago Press, 1993. Page 76.

48. Charles K. Bryant's rendering of the U.S. complex at the 1931 Exposition. "Sail to Reproduce Mt. Vernon in Paris." New York Times, 26 October 1930, p. N1.

49. Thomas Pritchard Rossiter and Louis Remy Mignot, "Washington and Lafayette at 1859 at Mount Vernon, 1784 (The Home of Washington after the War)," 1859, oil on canvas. The Metropolitan Museum of Art. 2006. <http://www.metmuseum.org/> 27 April 2006.

50. Lafayette's bedroom as reproduced in the 1931 United States Building.. "Historic Mount Vernon Goes to Paris." Houston Chronicle, 22 February 1931.

51. Anne Madison Washington. "Interior Expert." Washington Post, 7 December 1930, p. A6.

52. Good Housekeeping's coverage of the 1931 Paris Exposition replica with emphasis on the manufacturers of the reproduction furniture. "Replica of Mount Vernon at the International Colonial Exposition in Paris." Good Housekeeping 92, no. 5 (May 1931): 68-9+.

53. Mount Vernon replica erected in Prospect Park for the 1932 New York City Bicentennial celebration of Washington's birthday. George Washington Bicentennial Commission. Official Handbook of the Replica of Mount Vernon in Prospect Park, Brooklyn. 1932. Page 2.

54. Bryant's rendering of the Prospect Park replica. "Park Site Suitable to New Mt. Vernon." New York Times, 6 March 1932, p. N3.

55. Federal Hall replica erected in Bryant Park, Manhattan, for the 1932 New York City Bicentennial celebration of Washington's birthday. The building was contracted by Sears, Roebuck and Company. "Washington Rides Amid Din of Wall St. in Pomp of Old Days." New York Times, 1 May 1932, p. 1.

56. List of furniture in the 1932 replica by room. George Washington Bicentennial Commission. Official Handbook of the Replica of Mount Vernon in Prospect Park, Brooklyn. 1932. Pages 30-31.

57. "The Jefferson." Sears, Roebuck and Company. Sears Archives. 1 March 2005.

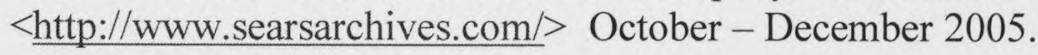


58. "The Mount Vernon." Stevenson, Katherine Cole. Houses by Mail: A Guide to Houses from Sears, Roebuck and Company. Washington, D.C.: Preservation Press, 1986. Page 256.

59. "The Martha Washington." Stevenson, Katherine Cole. Houses by Mail: A Guide to Houses from Sears, Roebuck and Company. Washington, D.C.: Preservation Press, 1986. Page 325. 


\section{INTRODUCTION}

The replication of Mount Vernon during the late nineteenth and early twentieth centuries served a range of purposes (Figures 1-4). Each version represented a different group's attempt to define their identity through their memory of George Washington, his home, and America's early history. These memories, therefore, were constructed in order to serve these identities and to provide a backdrop for the presentation of each replica. This thesis follows the ways in which Mount Vernon was appropriated for different collective memories - the regional, national, and Colonial Revival - throughout the late nineteenth and early twentieth centuries and demonstrates that while Mount Vernon has been ever-present in American iconography, its meaning has never been fixed.

The Virginia Building at the 1893 World's Columbian Exposition in Chicago, Illinois, was the first in a series of reproductions of Mount Vernon at world's fairs or otherwise significant public events, and thus its conception and construction served as a turning point in the history of Mount Vernon in American memory (Figures 5-9). This initial replica represented two narratives. One was regionally specific to Southern identity and enlisted the building in the movement to memorialize the Lost Cause myth, whereas the other narrative was part of a longer national tradition of the memory of Washington and Mount Vernon that was emerging in American culture in the late nineteenth century. This narrative found its consummation in the Colonial Revival. Both narratives, despite their differences, were intent on depicting some version of an idealized domesticity of Washington and his iconic home. The domestic realm presented at the 1893 Virginia Building and the subsequent replicas presented an uncritical and uncontroversial view of antebellum American life. In addition, both narratives were 
central to the roles of late nineteenth and early twentieth-century women as historic preservationists and guardians of public memory. Though both of these narratives shaped the meaning of the 1893 Virginia Building, the replicas that followed increasingly focused upon the national connotations of Mount Vernon as concepts and tropes of early American domesticity grew more commercialized.

In the first chapter of this thesis, I describe the establishment of Washington and Mount Vernon as domestic icons leading to the years of the Civil War and discuss how these themes became part of both national and regional movements that framed the narratives of the 1893 Virginia Building and subsequent replicas. While George Washington may be read in many ways, his role as head of America's most iconic household was most closely tied to the nation's interpretation of Mount Vernon and his domestic life. Soon after his death, Washington was admired in imagery and literature for his preference for a life as the head of a substantial agricultural household over the rigorous duties of military and state leadership - his inclination to be the patriarch of a household rather than father of a nation. Mount Vernon was central to the American memory of the first president not only as a personal symbol, but also as an expression of his ideal domestic values - values that kept him close to the land, true to his family, and always made him an impeccable host. These ideals were among the motivations of a group of women to save the house and restore it to its proper role as an aristocratic homestead, and to preserve it as an ideal of American domesticity.

After the Civil War, these themes were commodified by the Colonial Revival, a broad repackaging of early American history shaped by perceived threats to the domestic 
realm including immigration, urbanization, and industrialization. American women embraced a version of Colonial life that was simplified and idealized as an example of how domestic values could be reformed in a rapidly changing world. This impulse spawned not only an increase in Colonial Revival-inspired commodities, but also a social movement of elite women's groups founded to shape and preserve idealized versions of American history. The national narrative of the Virginia Building and the replicas that followed depended upon the Colonial Revival, a theme that would have been recognizable to all Americans and undoubtedly contributed to the popularity of Mount Vernon replicas.

Similarly, regional movements in the South propelled by the feminine elite adopted the memory of the Colonial and Revolutionary periods. The goal of these groups was not to combat industrialization, but to remediate the history of the South after the Confederacy's loss and to emphasize the role of domestic values. In order to legitimize the culture and cause for which the Confederates had fought, Southern white women crafted the Lost Cause myth by drawing direct connections between the shared American past of founding fathers, the battle over "states" rights," and the contemporary struggle by the Southern elite to regain political and social control over the region.

In the second chapter, I discuss how this multivalent interpretation of early American history, and specifically Mount Vernon, was adapted in the Virginia Building. Because Virginia was essential to the argument of the Lost Cause myth as the home of founding fathers like Washington, the regional narrative formed the nexus for the 1893 state building. Outwardly the building had nothing to do with the Confederacy and was the obvious choice for the state as an architectural expression of Virginian identity; its 
players and the moment in which it was created, however, embed it in the burgeoning tradition of the Lost Cause myth. Most importantly, the leadership of women in the creation and daily maintenance of the Virginia Building ensured that not only was the building and its process firmly rooted in the movement to commemorate the Lost Cause, but also that the replica was understood as a functioning home, a complete recreation of an antebellum domestic atmosphere.

This regional narrative would persist through representations of Virginia until World War I. The 1907 Jamestown Ter-Centennial Exposition, a world's fair held on Virginia soil and celebrating Anglo-Saxon Virginia history, commemorated the regional narrative much more overtly than the 1893 Virginia Building. Although the fair did not host a replica of Mount Vernon, the memory of the state presented was directly in keeping with that of the regional narrative exemplified by the 1893 Virginia Building. This interpretation would continue in the 1915 replica of Mount Vernon constructed as the Virginia Building for the Panama Pacific International Exposition in San Francisco, California.

I describe the replicas of Mount Vernon that were constructed after World War I in my third and final chapter. By the 1926 Philadelphia Sesqui-Centennial Exposition, the specifically Southern connotations found in early Mount Vernon replicas had faded. At the Philadelphia fair the Young Women's Christian Association constructed a replica of Mount Vernon to serve as a cafeteria and welcome center, embodying quite different intentions than its predecessors. Thereafter, the United States built a replica of Mount Vernon to represent the entire nation at the 1931 Paris International and Colonial Overseas Exposition. The next year, a version of Mount Vernon was erected in 
Brooklyn, New York to celebrate the bicentennial of Washington's birth. Though these later replicas did not maintain the allusions to Southern elitism and the Lost Cause myth, they did perpetuate a memory of an idealized Colonial American domesticity and had an overtone of social exclusiveness - they merely lost their direct regional references.

Ironically, the reproductions of Mount Vernon that began by symbolizing such restrictive memories of Colonial American domesticity led to the democratization of the Mount Vernon domestic model. By 1932, Sears, Roebuck and Company were selling a prefabricated version of Mount Vernon through their catalogue, making the famous architectural symbol available to all Americans who could afford to purchase its likeness. By the 1930s, a world war, national crises, and the fading of the living memory of the Civil War had laid aside sectional differences to allow Mount Vernon to be more egalitarian.

This argument engages two bodies of scholarship: that focused on George Washington and the Colonial Revival's place in American culture (in works such as Karal Ann Marling's George Washington Slept Here and Richard Guy Wilson's The Colonial Revival House) and that interested in the fashioning of the Lost Cause myth by late nineteenth century elite women (exemplified by the work of Fitzhugh W. Brundage). Both fields are concerned with concepts of public and collective memory based upon the theories of Maurice Halbwachs in his book, The Collective Memory, and exemplified in a particularly American context by Michael Kammen in his works Mystic Chords of Memory: The Transformation of Tradition in American Culture and A Season of Youth: The American Revolution and the Historical Imagination. James M. Lindgren's book, 
Preserving the Old Dominion: Historic Preservation and Virginia Traditionalism, also served as a key resource in my arguments on the regional aspects of memory. My methodology is in keeping with these works in that it looks to collective memory as the motive for architectural choices. This thesis is concerned with Mount Vernon and how it was appropriated by various collective memories at specific events between the World's Columbian Exposition and the celebration of the bicentennial of Washington's birth. It is not meant to be a comprehensive discussion of the public memory of George Washington, Colonial American domesticity, or Mount Vernon, but a close reading of how Mount Vernon was interpreted through the late nineteenth and early twentieth centuries. 


\section{CHAPTER I: \\ George Washington, Mount Vernon, and the Memory of Colonial American Domesticity}

All of the replicas of Mount Vernon created for world's fairs or otherwise significant public celebrations between 1893 and 1932 relied upon a nationally established reading of Washington as a domestic icon and Mount Vernon as the physical expression of his domestic values. This interpretation of Washington and his home was expressed through text, imagery, and the fight to preserve Mount Vernon. In addition, the replicas were part of the Colonial Revival, an attitude towards American history that became increasingly interested in the domestic sphere after the Civil War. The Colonial Revival inspired commercialization of the concepts of American domesticity as well as movements of white women to serve as stewards of early American memory and domestic values. Those who created the earliest facsimiles also incorporated a regional narrative, embedding their interpretation of Mount Vernon within the late nineteenth century movement by Southern white women to "preserve" the dignity of elite antebellum society.

\section{Mount Vernon and George Washington as Icons of Colonial American Domesticity}

The root of both the regional and national narratives expressed in the duplication of Mount Vernon for world's fair buildings has endured in the national memory of Colonial American history since Washington's lifetime; the architecture has been understood as a reflexive icon, inseparable from its maker in the American consciousness. ${ }^{1}$ The first president existed as an emblem of ideal American values before

\footnotetext{
${ }^{1}$ Jan Cohn, The Palace or the Poorhouse: The American House as a Cultural Symbol (East Lansing: The Michigan State University Press, 1979), 197.
} 
the nation was even formed; once independence was won, his image provided stability for America's growing canon of national symbols. ${ }^{2}$ Domesticity was almost always acknowledged as integral to this iconography, and most often represented by the image of Mount Vernon. By recalling Mount Vernon, the replicas evoked the icon of Washington through the architecture of his home. ${ }^{3}$ While Washington was first and foremost remembered as a great military and civic leader, his devotion to his family and home were also central to the ways in which Americans identified with him.

Washington's insistence throughout his life that he was first and foremost a planter and only secondarily a soldier and statesman resulted in comparisons with the Roman legend Cincinnatus in the late eighteenth century, dividing his image into two distinct but equally important components: the gentleman farmer and the military and civic leader. This dual character description was solidified by Mason Lock Weems's The Life of Washington, published within a year of the president's 1799 death and what would become the leading and defining biography of George Washington. ${ }^{4}$ The inaugural biographer described the duality of the first president:

He beats his ploughshare into a sword, and exchanges the peace and pleasures of his farm for the din and dangers of the camp...He awakes, in his silent chambers at Mount Vernon, without sighing for the sprightly drums and fifes that used to salute him every morning... The useful citizen is the high character he wishes to act-his sword turned into a ploughshare is his favourite instrument, and his beloved farm his stage. ${ }^{5}$

\footnotetext{
${ }^{2}$ Gary Wills, Cincinnatus: George Washington and the Enlightenment: Images of Power in Early America (New York: Doubleday \& Co., 1984), xxi.

${ }^{3}$ For Washington's involvement with the design of Mount Vernon, see Allan Greenberg, George Washington: Architect (New York: Andreas Papadakius Publisher, 1999); Robert F. Dalzell, Jr. and Lee Baldwin Dalzell, George Washington's Mount Vernon: At Home in Revolutionary America (New York: Oxford University Press, 1998).

${ }^{4}$ Michael Kammen, A Season of Youth: The American Revolution and the Historical Imagination (New York: Alfred A. Knopf, 1978), 41-2.

${ }^{5}$ Mason Lock Weems, The Life of Washington, (1799; reprint, with primary documents and an introduction by Peter S. Onuf, Armonk: M. E. Sharpe, 1996), 103. Emphasis in originial.
} 
Weems emphasized Washington's preference for his life as a plantation owner at Mount Vernon, his military and civic accomplishments being only a reluctant duty. ${ }^{6}$ While the importance is placed on Washington's work as a planter, the presence of Mount Vernon (and often also Martha Washington) in such descriptions and similar images as well as the comfortable life allowed by Washington's wealth and slave ownership, presented a vision of the man in a domestic setting. Washington's agricultural, familial, and land interests were totaled as a domestic foil to his civic and military service and his preference for the former was emphasized as admirable throughout the nineteenth century.

This reverence for Washington's domestic life is clear in John Trumbull's oil painting of the 1820s (Figure 10), "The Resignation of George Washington." In the pictured scene, Washington leaves his military life and defers civic leadership, represented by the group of political leaders to his right, for his domestic realm, defined by the women and children to his left; ${ }^{7}$ he would rather serve as the patriarch of a family than of a country. Martha Washington is prominently featured at the apex of the gallery's pediment to emphasize this point. Also, while all but three of the male figures in the painting can be identified as particular political leaders, only the depiction of Martha Washington is based on the likeness of a specific woman; all of the other women and children in the painting are illustrated to convey a general concept of the domestic world

\footnotetext{
${ }^{6}$ See Wills, Cincinnatus for a discussion of Washington's own attempts to control and to craft this image in American memory throughout his life.

${ }^{7}$ Wills, Cincinnatus, 14-16.
} 
that Washington preferred rather than referring to specific people actually present at the event. $^{8}$

Mount Vernon was the ultimate symbol of this domestic side of Washington, and was referenced as such constantly in antebellum imagery. In John James Barralet's "George Washington's Resignation" and its subsequent adaptations dating to the last decade of the eighteenth century, Mount Vernon served as the counterpoint to public life and notoriety as embodied by the gesturing goddess (Figure 11). ${ }^{9}$ The repetition of the theme of Washington's resignation from public service is testament to how widely his domestic values were revered; his preference for a "simple" life as a planter and husband over political and military power was seen as exemplary. The centrality of the image of Mount Vernon, Washington's house, emphasized the reading of the first president's domestic life and values as especially laudable.

By the mid-nineteenth century, Washington's domestic life was even more emphatically emphasized in imagery. ${ }^{10}$ Junius Brutus Stern's antebellum series of paintings of Washington, most of which feature Mount Vernon, depict him as a farmer, a soldier, a husband, and as a dying mortal. Stern's 1851 painting of Washington in the fields with African American slaves, however, suggests another aspect of Washington and life at Mount Vernon that would not have escaped the contemporary observer given the highly controversial passage of the Fugitive Slave Law the previous year (Figure 12). ${ }^{11}$ This painting not only recalls Washington and his relationship to the institution of

\footnotetext{
${ }^{8}$ The identification of the figures of Trumbull's painting is explained in John Hill Morgan, Paintings by John Trumbull at Yale University of Historic Scenes and Personages Prominent in the American Revolution (New Haven: Yale University Press, 1926), 62-66.

${ }^{9}$ Wills, Cincinnatus, 12-14.

${ }^{10}$ Barbara J. Mitnick, "Parallel Visions: The Literary and Visual Image of George Washington," in George Washington: American Symbol, ed. Barbara J. Mitnick (New York: Hudson Hills Press, 1999), 65.

11 "American Art and Memory," 27 September 2005.
} 
slavery as benign, but would have reminded the contemporary observer of his regional identity: Washington was a slaveholder and, therefore, a Southerner. ${ }^{12}$ Popular genre painter Eastman Johnson's oil depictions of Mount Vernon from the same decade similarly emphasized Mount Vernon as a Southern plantation. "Mount Vernon Kitchen" of 1857 is entirely focused on the romanticized, hearth-lit evening of an enslaved servant and her children, the only reference to Mount Vernon being the painting's title (Figure 13). ${ }^{13}$ While Mount Vernon symbolized the domestic life of Washington, it also served as a reminder that he and his home were still Southern in the years leading into the Civil War.

\section{Mount Vernon's Unifying Domesticity}

While Washington and Mount Vernon were inseparable in American memory as symbols of Colonial domesticity, the house itself also had more specific connotations. The battle over the building's preservation in the years leading up to the Civil War solidified it as a female-oriented, domestic icon, yet with more inclusive political associations and exclusive social implications. The shift of focus from the building and its maker's regional identities to a more inclusive, national outlook mirrored the shift in narrative that occurred with the late nineteenth and early twentieth-century replicas.

American tourists and foreign visitors had long been visiting Mount Vernon with hopes of better understanding the first president. During and well after Washington's

\footnotetext{
${ }^{12}$ William M. S. Rasmussen and Robert S. Tilton, George Washington: The Man Behind the Myths (Charlottesville: University Press of Virginia, 1999), 192-93.

${ }^{13}$ Karal Ann Marling, George Washington Slept Here: Colonial Revivals and American Culture, 18761986 (Cambridge: Harvard University Press, 1988), 66; Theresa A. Carbone and Patricia Hills, eds., Eastman Johnson: Painting America (Brooklyn: Brooklyn Museum of Art, 2000), 122-25; Patricia Hills, The Genre Painting of Eastman Johnson: The Sources and Development of His Style and Themes (New York: Garland Publishing, 1977), 54-5.
} 
presidency, visitors were welcomed into the house like guests or known acquaintances.

Throughout these years, the estate was owned and maintained by the Washington family, who accommodated visitors by providing refreshments, tours, and even souvenirs. By the 1840 s, however, the family's inability to maintain both the aging building and the timeworn Southern tradition of hospitality was seen as a threat (Figure 14). The high volume of visitors to the plantation - over 10,000 a year by the 1850 s - made the ruinous state of the building publicly obvious and potentially embarrassing. The great mythmaker of Southern, and particularly Virginia history, Thomas Nelson Page, remarked of Mount Vernon and its keepers' duty:

The rule was to keep open house for all who came. The hospitality was of the abounding kind. No class of men ever had greater calls made on their generosity or responded more graciously [than the Southern country gentry]... in this case, that which sprang from the position of Mount Vernon as the most noted and most visited country seat on the continent, the exactions were far more than any private fortune in Virginia could support. $^{14}$

The ability of the house to remain hospitable - to be open for its nation's citizens - was essential to the maintenance of Mount Vernon's role as an icon of privileged Southern domesticity. Mount Vernon, the "first house" of America, had to remain accessible in order to serve as an example for other aristocratic Southern homes.

The movement to save Mount Vernon began in the South: Ann Pamela Cunningham (1816-75, Figure 15), a South Carolinan, founded and led its preservation through the tumultuous period of the Civil War. ${ }^{15}$ Her initial cry for Southern women to

\footnotetext{
${ }^{14}$ Thomas Nelson Page, Mount Vernon and Its Preservation, 1858-1910 (New York: The Knickerbocker Press, 1910), 13

${ }^{15}$ The concept of preserving Mount Vernon was first introduced to Ann Pamela Cunningham by her mother, native Virginian Louisa Dalton Bird Cunningham. For a version of the mythical realization of Louisa Dalton Bird Cunningham to save Mount Vernon, see Grace King, Mount Vernon on the Potomac (New York: The Macmillan Company, 1929), 13-14. For an account of Cunningham's life, see Mount
} 
give money and support to the cause were made December of 1853 in an "Appeal to the Ladies of the South," published in the Charlestown Mercury. In the testament, Cunningham would identify herself as "A Southern Matron" and define the cultural and economic threats to the South, symbolized by the possibility of outside [Northern] land speculators purchasing Mount Vernon. ${ }^{16}$ Cunningham begins the petition:

A descendent of Virginia, and now a daughter of Carolina, moved by feelings of reverence for departed greatness and goodness, -by patriotism and a sense of national and, above all, of Southern honour, -ventures to appeal to you in behalf of the home and grave of Washington!, ${ }^{17}$

This statement makes clear Cunningham's regional associations and motivations. By appealing to the "cult of Southern womanhood," Cunningham was asking Southern women to act within their bounds and duties as republican mothers, yet to take control in a legislative matter. ${ }^{18}$ In this way, Cunningham kept the movement to save Mount Vernon out of the sectional politics that rocked the region and put the stewardship of the nationally significant historic site in the hands of women.

Southern women responded to Cunningham's pleas; in order to save the house from imagined land speculators, physical ruin, and other possibilities that would limit its accessibility, the Mount Vernon Ladies' Association (MVLA) was formed (Figure 16). ${ }^{19}$ The MVLA held their first meetings in Richmond, Virginia's Metropolitan Hall in 1854,

\footnotetext{
Vernon Ladies' Association, Historical Sketch of Ann Pamela Cunningham: "The Southern Matron," Founder of the 'Mount Vernon Ladies' Association (New York: Marion Press, 1903).

${ }^{16}$ For the complete text of this appeal, see King, Mount Vernon on the Potomac, 19-22.

${ }_{17}^{17}$ Ann Pamela Cunningham in the Charleston Mercury quoted in King, Mount Vernon on the Potomac, 19.

${ }^{18}$ West, Domesticating History, 8.

${ }^{19}$ Charles B. Hosmer, Jr., Presence of the Past: A History of the Preservation Movement in the United States Before Williamsburg (New York: G. P. Putnam's Sons, 1965), 41-62; Patricia West, Domesticating History: The Political Origins of America's House Museums (Washington: Smithsonian Institution Press, 1999), 1-37; Steven Conn, "Rescuing the Homestead of the Nation: The Mount Vernon Ladies" Association and the Preservation of Mount Vernon," Nineteenth Century Studies 11 (1997): 71-93.
} 
initiating the project as a Southern, and particularly a Virginian endeavor. ${ }^{20}$ Thus ensued a battle between the Virginia state legislature, the federal government, and the MVLA that continued throughout the decade, until the organization acquired the funds and the permission to purchase the land from John Washington in March 1858.

Quickly, however, it became clear that the Southerners could not provide all of the funding necessary for the preservation of Mount Vernon and Cunningham expanded her appeal to include Northern women. ${ }^{21}$ She would account for this extension in her petitions: "Washington belonged not alone to the South! ... Washington belonged not to one State alone! Devoted women would be neither baffled nor conquered; but she alone triumphs when the common homestead can be procured as a common heritage..., ${ }^{, 22}$ By appealing to American women rather than just Southerners, Cunningham established a metaphor in which Mount Vernon and Washington were symbols of a shared American legacy and the preservation of the house stood for the perpetuation of the Union. She would apply this concept directly in her calls for action from American women:

...when the Ship of State, with no master hand at the helm, rocked to and fro on the angry waves of sectional strife and bitterness which threatened to engulf it; has stirred the heart of woman to revive, through the rescue of sacred ashes of the Father of his Country, that love for his memory.... which could be made all-powerful in regenerating healing influences. $^{23}$

While the government was too conflicted to hold itself together and certainly too busy for historic preservation, America's women took on the responsibility to remedy both situations, yet still remain in their accepted roles. Preservation was understood as an

\footnotetext{
${ }^{20}$ Elizabeth R. Varon, We Mean to Be Counted: White Women and Politics in Antebellum Virginia (Chapel Hill: The University of North Carolina Press, 1998), 124.

${ }^{21}$ The MVLA enlisted orator Edward Everett to aid in their campaign to raise money nationally, and especially in the North. See Edward Everett, The Mount Vernon Papers (New York: D. Appleton and Company, 1860).

${ }_{22}^{2}$ Ann Pamela Cunningham, in Mount Vernon Record 1, no. 1 (July 1858): 1. Emphasis in original.

${ }^{23}$ Cunningham, in Mount Vernon Record. Emphasis in original.
} 
acceptable past time for Victorian-era women. ${ }^{24}$ By restoring homes, the women were retaining their domestic sphere; because women were removed from politics and the "corrupting" world of men, their hold on the nation's historical memory was made pure by their domesticity. ${ }^{25}$ As keepers of memory, they would carry on the tradition of republican motherhood.

Yet only the white elite had the temporal and financial resources to participate in such endeavors, limiting those whom Cunningham and the MVLA could address and consequently indicating that their version of domesticity was elitist. ${ }^{26}$ To delegate responsibility of the organization's affairs, Cunningham appointed a series of regents, one for each state in the Union, to raise funds and gather relics locally for the Mount Vernon cause. All of the early regents were similar in that they were wealthy, prominent members of their communities and somehow genealogically related to the founding fathers, ${ }^{27}$ foreshadowing the exclusivity of such women's ancestry clubs that would form in the last decades of the nineteenth century.

During the Civil War, Mount Vernon was "the only spot in all our now United States where soldiers of both armies could meet on neutral ground." ${ }^{28}$ It remained a space that was non-partisan in a divided nation, and therefore a symbol of union. A Northerner, Sarah Tracey, and a Southerner, Upton Herbert, guarded Mount Vernon

\footnotetext{
${ }^{24}$ William B. Rhoads, The Colonial Revival (New York: Garland Publishing, 1977), 416.

${ }^{25}$ Conn, "Rescuing the Homestead of the Nation," 73.

${ }^{26}$ Conn, "Rescuing the Homestead of the Nation," 75.

${ }^{27}$ West, Domesticating History, 17.

28 "Restoration of Mount Vernon," The Sunday Sentinel (Milwaukee), 8 August 1897, p. 1.
} 
throughout the war as word spread about the new circumstances of the house through visiting soldiers. $^{29}$

Thanks to the highly publicized actions of a group of patriotic white women, Mount Vernon remained neutral ground throughout the Civil War, despite the politics that swarmed around it. By purchasing the house and restoring it with relics of Washington's domestic life, the Mount Vernon Ladies Association ensured that the icon could remain domestic - the home that it had been during Washington's lifetime. Cunningham said of the restoration: "[t]he mansion and the grounds around it should be religiously guarded from change-should be kept as Washington left them." ${ }^{930}$ Central to this concept of domesticity was the maintenance of a level of hospitality expected of such a Southern, aristocratic home; it would remain open to the public. Mount Vernon had become a shrine to an idealized version of Colonial American domesticity, presided over by a group of supposedly bi-partisan, ${ }^{32}$ elite, white women who felt it their duty to guard and preserve the iconic building. Cunningham's pleas were highly publicized and established an undeniable link between Mount Vernon, domesticity, and union that would last throughout the nineteenth century and would prove essential to the Virginia Building of 1893. Just as women used Mount Vernon as a symbol and example of union through Mount Vernon's preservation, Virginia women would appropriate the building's image as a means to reconcile the North and South with its replica.

\footnotetext{
${ }^{29}$ West, Domesticating History, 34. For an account of Mount Vernon during the Civil War, see Dorothy Troth Muir, Presence of a Lady: Mount Vernon, 1861-1868 (Washington: Mount Vernon Publishing Company, 1946).

${ }^{30}$ Ann Pamela Cunningham, 1 June 1874, quoted in Page, Mount Vernon and Its Preservation, 62.

${ }^{32}$ There was strife within the MVLA over the fact that Cunningham returned to her home of South Carolina during the Civil War instead of staying in the depoliticized zone of Mount Vernon's grounds. See West, Domesticating History, 30-35.
} 


\section{The National Narrative: The Colonial Revival in Post-Civil War America}

While the replicas of Mount Vernon were dependent upon the long-established relationship between Washington, his home, and domestic values, they also exemplified a national attitude towards the Colonial period: the Colonial Revival. The domestic values central to the imagery of Mount Vernon at once supported and were complemented by the retrospective approach to architecture and consumer goods. This relationship formed the nexus of the national narrative that ran through all of the replicas of the home, from the 1893 Virginia Building to Sears and Roebuck's prefabricated version of 1932.

By the end of the Civil War, Revolutionary and Colonial symbols had been appropriated by so many different groups that they had essentially lost meaning: the over-

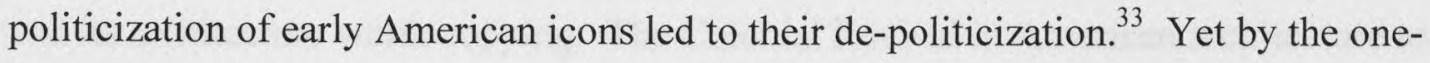
hundredth anniversary of the signing of the Declaration of Independence, Americans were using their shared memory of the Revolutionary heroes as a means to heal sectional wounds. ${ }^{34}$ When the Colonial and Revolutionary periods were employed to smooth over the sectional conflict of the 1860 s, issues such as slavery that had been so central to the fight were diminished to further idealize and simplify points of contention in hopes to optimize the appeal of reconciliation. ${ }^{35}$ Memories of Colonial domesticity were central to this re-appropriation of the Colonial Revival; they were understood as a means to "save" contemporary American domestic values. Just as the home had supposedly been the repository of ethical living in the Colonial period (such as Mount Vernon was for

\footnotetext{
${ }^{33}$ Kammen, A Season of Youth, 58.

${ }^{34}$ Kammen, A Season of Youth, 59-65. Like the appropriation of Mount Vernon by the MVLA, early American history was used as a unifying memory.

${ }^{35}$ Kammen, A Season of Youth, 61.
} 
George Washington), it would be once again in the late-nineteenth century through the domestication of the Colonial Revival. ${ }^{36}$

Although the Colonial Revival had existed well before the Civil War, ${ }^{37}$ its domestic associations were emphasized in the late nineteenth century as a countermovement to America's rapid industrialization, urbanization, commercialization, and technological development. ${ }^{38}$ These drastic social changes forced middle-class Americans to reconsider their social ideals and to reevaluate the role of the home in American life. Colonial American domestic architecture was idealized for the very aspects by which it so dramatically opposed the busy Victorian; ${ }^{39}$ the simplicity and supposedly purely American undertones made the Colonial period worth remembering and its architecture worth copying. The Colonial Revival in American architecture as explained by architectural historian Vincent Scully "was something of a real desire for a new simplicity, associated with an old simplicity, as well as seeking for amplitude and ease." ${ }^{40}$ These values would be translated directly into the Virginia Building of 1893 and its successors. In a paper read at the Exposition regarding the importance of colonial Virginia to the nation, these points are emphasized:

From the pretty and vivid picture [drawn] of the home-life of Washington, we may learn how unpretentious the truly great can dare to be, and the simple manner of living chosen by the family of that honored son of old

\footnotetext{
${ }^{36}$ David Scobey, "What Shall We Do with Our Walls? The Philadelphia Centennial and the Meaning of Household Design," in Fair Representations, eds. Nancy Gwinn and Robert W. Rydell (Amsterdam: VU University Press, 1994), 114-15.

${ }^{37}$ Richard Guy Wilson, The Colonial Revival House (New York: Harry N. Abrams, Inc., 2004), 12-33.

${ }^{38}$ Clifford Edward Clark, Jr., The American Family Home, 1880-1960 (Chapel Hill: The University of North Carolina Press, 1986): 132-147.

${ }^{39}$ Clark, The American Family Home, 131; Bridget A. May, "Progressivism and the Colonial Revival: The Modern Colonial House, 1900-1920," Winterthur Portfolio 26, no. 2-3 (Summer-Autumn 1991): 107-122.

${ }^{40}$ Vincent J. Scully, Jr., The Shingle Style: Architectural Theory and Design from Richardson to the Origins of Wright (New Haven: Yale University Press, 1955), 27-28.
} 
Virginia...It is really an enjoyment to be here to witness the tranquil happiness that reigns throughout the house... ${ }^{41}$

This nostalgia for a simpler lifestyle found in "old Virginia" would have been an effective foil to the dramatic technological and industrial innovations typically displayed at world's fairs and could explain one of the reasons why the attraction proved so popular.

While the central concept behind the Colonial Revival was a return to the supposed simplicity of the Colonial period, the preference for American architecture as an alternative to European models was also a cry for nationalism when American cities were becoming inundated with immigrants from all over Europe. ${ }^{42}$ An architecture critic of the 1920s would describe the architectural approach as "an expression of the wish to build what really 'belongs'-to add to the beauty of a village or landscape by building in harmony with its forms and its history. ${ }^{, 43}$ It was a native style that harked back to a time when life was simple and society was easily controlled before complications like ethnic diversity.

George Washington and his Mount Vernon were obvious icons of this Colonial memory. Just like the Colonial Revival, Washington stood as a conservative, steadfast example of order and straightforward honesty in a difficult time. ${ }^{44}$ Even the MVLA's antebellum campaign to save the house focused on its simple, yet pure domesticity as a

\footnotetext{
${ }^{41}$ Mary Mann Page Newton, Colonial Virginia: A Paper Read Before the Historical Congress at Chicago (Richmond: West, Johnston \& Co., Publishers, 1893), 15.

${ }^{42}$ William B. Rhoads, "The Colonial Revival and American Nationalism," The Journal of the Society of Architectural Historians 35, no. 4 (December 1976): 239-254.

${ }^{43}$ Talbot Faulkner Hamlin, The American Spirit in Architecture (New Haven: Yale University Press, 1926), 263.

${ }^{44}$ Marling, George Washington Slept Here, 76. Washington was such an uncontested hero that he became the only president whose death centennial was commemorated. See Barry Schwartz, "George Washington: A New Man for a New Century," in George Washington: American Symbol; ed. Mitnick, 127-133.
} 
means to rehabilitate American values, ${ }^{45}$ a crisis brought to the surface by the conflict of the Civil War. Mount Vernon was central to Washington's image and therefore stood as the paragon of Colonial Revival domestic architecture; if Washington was the most obvious figurehead of the movement, then his home was his architectural equivalent. In Paul Leicester Ford's 1896 biography of Washington that was instrumental in further humanizing Washington for the turn of the century, ${ }^{46}$ he credits Mount Vernon for the balance of the first president's character: "Such was his feeling for the place that he never seems to have been entirely happy away from it..."47 Mount Vernon's role as the most often replicated and visited Colonial home in the years to come would attest to its position as the clearest symbol of the values evoked through the Colonial Revival.

Besides the fact that the Colonial Revival most often called forth or was used in domestic architecture, it was also a movement largely in the hands of American women. ${ }^{48}$ One of the most public (and popular) displays of the Colonial Revival was the 1876 United States International Exposition in Philadelphia, Pennsylvania (popularly called the Centennial), where a strong appeal was made to American domestic values. ${ }^{49}$ The Centennial marked the first time that the United States hosted a world's fair and featured the rapid industrialization of America's post-Civil War years. The social implications of these drastic shifts in American society and the nation's international role reinforced the impetuses of the affection for the idealized simplicity of the Colonial period. The American home and the role of the American woman were reclaimed as a place where

\footnotetext{
${ }^{45}$ Conn, "Rescuing the Homestead of the Nation."

${ }^{46}$ See Barry Schwartz, "George Washington," 122-139.

${ }^{47}$ Paul Leicester Ford, The True George Washington (Philadelphia: J. B. Lippincott Company, 1896), 113.

${ }^{48}$ Wilson, The Colonial Revival House, 7.

${ }^{49}$ David Scobey, "What Shall We Do with Our Walls?;" Kammen, A Season of Youth, 59-69.

${ }^{51}$ Scobey, "What Shall We Do with Our Walls?," 114-15; Marling, George Washington Slept Here, 52.
} 
the civic order had begun and could be revived, reestablishing the home as a place of escape and safety from the rapidly changing world. ${ }^{51}$ The Colonial Revival came into the home through a wide array of "olde-tyme" domestic products and concepts, ${ }^{52}$ many created or marketed for the Centennial specifically. The Centennial's "Old New England Log-House," serving supposedly Colonial period food by attendants in Colonial period dress in a Colonial atmosphere, emphasized the "homey" domestic qualities of early American history (Figures 17 and 18). ${ }^{53}$ The exhibit defined Colonial domesticity in the two-roomed structure with "appropriate paraphernalia," some of which were actual period relics. ${ }^{54}$ Guests were ushered through the bedroom and living/kitchen spaces and asked to consider the objects "whose very simplicity made them incomprehensible to the victims of modern improvements." ${ }^{, 55}$ Part of the role of such exhibits and the proliferation of Colonial Revival trinkets and products at the fair was to educate women the keepers of this domestic sanctuary - of their new roles as diligent consumers. ${ }^{56}$ In order to provide a haven from the industrializing and urbanizing world, American women were ironically charged with manipulating its products. While the home was the showcase of the Colonial Revival, American women were its keepers and promoters. ${ }^{57}$

\footnotetext{
${ }^{52}$ Washington's own image adorned many of these products, though this had been in practice since his lifetime. See William Ayers, "At Home with George: Commercialization of the Washington Image, 17761876," in George Washington: American Symbol, ed. Mitnick, 90-107.

${ }^{53}$ Marling, George Washington Slept Here, 34; Rodris Roth, "The New England or 'Olde Tyme,' Kitchen Exhibit at Nineteenth-Century Fairs," in The Colonial Revival in America, ed. Alan Axelrod (New York: W.W. Norton \& Company, 1985), 159-83.

${ }^{54}$ J. S. Ingram, The Centennial Exposition, Described and Illustrated Being a Concise and Graphic Description of this Grand Enterprise Commemorative of the First Centenary of American Independence... (Philadelphia: Hubbard Bros., 1876), 706-08.

55 J. S. Ingram, The Centennial Exposition, 706-08. Emphasis added. The "old-tyme" way of life was made more nostalgic in contrast with the adjoining exhibit on the modern home, featuring modern domestic technology.

${ }^{56}$ Gwendolyn Wright, Building the Dream: A Social History of Housing in America (New York: Pantheon Books, 1981), 111.

${ }^{57}$ Rhoads, The Colonial Revival, 425.
} 
American women were called upon not only to revive idealized Colonial

American domestic values as consumers, but also as stewards of its historical memory. With the precedent of the MVLA very much in mind, white elite women set forth to recall and redefine the nation's history, to relate the tumultuous present with America's supposedly more stable past. By the early 1890 s, groups were forming nationally to establish women as the keepers and preservationists of early American history. While their purposes were most often social in nature, ${ }^{58}$ they were also exclusive and reflected the growing fear of the influx of foreign immigrants and the slackening social boundaries of the industrial period. ${ }^{59}$ Led by the Daughters of the American Revolution (DAR) founded by Mary Lockwood in $1890,{ }^{60}$ these groups based their membership on ancestral lineage: in order to join, a woman had to prove that she was a descendant of a patriot of the American Revolution. The result was an elite club and an attempt to create an aristocracy based on an idealized Colonial upper crust. ${ }^{61}$ These women took it upon themselves to be leaders of the historic preservation movement, focusing especially on homes significant to white, male political leaders. ${ }^{62}$ The creation of such women's groups confirmed what the establishment of the MVLA suggested half a century before: while history was in the hands of American women and the domestic sphere, the

\footnotetext{
${ }^{58}$ Wilson, The Colonial Revival House, 41.

${ }^{59}$ West, Domesticating History, 44; Marling, George Washington Slept Here, 87. Also popular in the years leading up to and following the Centennial were balls and "Martha Washington" teas that encouraged guests to dress in period costume and emulate the imagined American aristocracy of the Colonial era. Ironically, the white elite women were celebrating an idealized value of early American history - social exclusiveness - that was at odds with the very values that were so central to the Colonial Revival movement - simplicity and repose. This emphasis on Washington's social status was also reflected with the stress in the post-war period on Washington's refusal to accept a salary for his role as a civic leader. See Howard N. Rabinowitz, "George Washington as Icon: 1865-1900," in Icons of America, eds. Ray B. Browne and Marshall Fishwick (Bowling Green, Popular Press, 1978), 67-86.

${ }^{60}$ For a history of the DAR, see Martha Strayer, The D.A.R.: An Informal History (Washington, D. C.: Public Affairs Press, 1958).

${ }^{61}$ James M. Lindgren, Preserving the Old Dominion: Historic Preservation and Virginia Traditionalism (Charlottesville: University Press of Virginia, 1993), 6.

${ }^{62}$ West, Domesticating History, 45.
} 
participants and, therefore the memory, were limited to an exclusive portion of the population.

The Regional Narrative: The Memory of Washington and the Colonial Period in the American South

The national narrative of the Colonial Revival as a unifying, domestic movement was central to Virginia's choice of Mount Vernon for their state buildings of 1893 and 1915 as it symbolized that Virginia and the New South were willing to forge ahead as part of a larger union. Though the Virginia Building depended upon these strains of the public memory of Washington and his home, it also re-appropriated these symbols to serve a memory specific to the Southern elite. While the national narrative allowed the building to appeal to all of its visitors, the regional was a means for Southerners and the privileged group that created the exhibit to remediate their more recent memory.

This reliance upon a specifically Southern interpretation of the first president reflected an established tradition in the region. Before and throughout the Civil War, Confederate ideology repeatedly called upon the Revolutionary period to justify succession from the Union and to claim that Confederates were the true descendants of founding fathers' ideals. ${ }^{63}$ They used the fact that the heroes of the Revolution, including Washington, had owned slaves in order to justify the institution and social system that they were defending. ${ }^{64}$ Washington was a central figure to the South's argument for their

\footnotetext{
${ }^{63}$ Anne Sarah Rubin, "Seventy-six and Sixty-one: Confederates Remember the American Revolution," in Where These Memories Grow: History, Memory and Southern Identity, ed. Fitzhugh W. Brundage (Chapel Hill: University of North Carolina Press, 2000), 85-105.

${ }^{64}$ Rubin, "Seventy-six and Sixty-one," 91-92.
} 
right to secede; because he had served both as the central, unifying figure of the Revolutionary period and was also a Southerner, he was naturally the prime example. ${ }^{65}$

In the years preceding the war, Southerners reminded the nation that Washington and his image belonged to them, suggesting that he would have sided with the Southern states had he still been alive. In 1849 , a competition for the first equestrian statue of Washington was announced and the work was erected in what would become the capital of the Confederacy: Richmond, Virginia (Figure 19). While other cities had already created monuments to George Washington, ${ }^{66}$ it was particularly important for Virginia and the South to claim Washington's image in the years leading up to the Civil War; ${ }^{67}$ declaring Washington as a precursor to the Confederacy would later help to support their arguments for their rights as a state and as a region. The statue then became central to the Confederacy's use of Washington's memory: the unfinished monument would serve as the site of Jefferson Davis's inauguration as president of the Confederacy and its depiction was placed at the center of the seal of the newly succeeded nation (Figure 20).

After the Civil War, Washington's image and Colonial American memory were further domesticated; the nation-wide Colonial Revival and the general overuse of Colonial symbols and ideology during the war led to their de-politicization. Yet American memory in the South was taking a different route from the national story: instead of having issues of industrialization and urbanization to combat, as did most Northern cities, the South struggled with the stigma of having lost the country's only civil war. Just as white, privileged women were taking on the stewardship of historical

\footnotetext{
${ }^{65}$ Rubin, "Seventy-Six and Sixty-one," 94-96.

${ }^{66}$ For example, a giant column with a statue of Washington designed by Robert Mills was erected in Baltimore between 1814 and the 1830 s.

${ }^{67}$ Lauretta Dimmick, "'An Altar Erected to Heroic Virtue Itself': Thomas Crawford and His 'Virginia Washington Monument," American Art Journal 23, no. 2 (1991): 4-73.
} 
memory on a national level through organizations such as the DAR and the general domestication of the Colonial memory, the same social class of women was central to the revision and redefinition of history in the South through the establishment of the Lost Cause. In essence, Southern white women were carrying on a cultural war where the military campaign had left off. In order to honor the Confederate dead and to retaliate against drastic changes in social hierarchies, it was imperative that they re-establish the legitimacy of antebellum Southern culture. ${ }^{68}$

During the Civil War, women held a central role in the cause as keepers of the home front. By leading the community and civilian effort, white women were assuring that the domestic values and social hierarchies for which their husbands, brothers, sons, and fathers were fighting were maintained.$^{69}$ Both during and especially after the war, Southern women were the custodians of memory through the burial of the dead, a role that grew into a grander and more public memorializing as the region regained its financial footing.

By the 1880 s, white women were fighting the same war that they had been waging since the 1860 s yet on a different battlefield: they were no longer the wives and mothers of a reigning society of valiant Cavaliers but part of a "Lost Cause" that was threatened by the complete disruption of racial and social norms. Their response in the physical environment was the erection of monuments and memorials to remember the antebellum South as a revised, mythically idealized place where slaves were happy and

\footnotetext{
${ }^{68}$ Fitzhugh W. Brundage, "White Women and the Politics of Historical Memory in the New South, 18801920," in Jumpin' Jim Crow: Southern Politics from Civil War to Civil Right, eds. Jane Daily, Glenda Elizabeth Gilmore and Bryant Simon (Princeton: Princeton University Press, 2000), 115-39.

${ }^{69}$ Drew Gilpin Faust, "Race, Gender and Confederate Nationalism: William D. Washington's Burial of Latané," The Southern Review (Spring 1989): 297-307; Drew Gilpin Faust, "Altars of Sacrifice: Confederate Women and Narratives of War," in Divided Houses: Gender and the Civil War, eds. Catherine Clinton and Nina Silber (New York: Oxford University Press, 1992), 171-199.
} 
honor held true. ${ }^{70}$ By creating monuments to a carefully selected past, white women were proclaiming that the Southern elite had indeed regained power in the American South. ${ }^{71}$ As women were actually the ones to manipulate the past, they were also asserting the central role of domesticity to history and the formation of dutiful citizens of the future. ${ }^{72}$

The movement to memorialize the antebellum South was not limited to the commemoration of recent history, however, but stretched back to include the Colonial and Revolutionary eras as well. Just as the Confederacy had used Washington and his Southern compatriots as precursors of their own cause, women used Colonial history as a way to legitimize the Lost Cause myth that they were creating in the wake of the South's defeat. Southern women were proclaiming a more regional assertion to the national movement of the Colonial Revival and the primacy of domesticity and the role of women in Colonial history; the South may have lost the war, but its domestic values were still those of George and Martha Washington. The story of the Association for the Preservation of Virginia Antiquities (APVA) is an example of this redefinition of Colonial history in the South. Though not consisting of women entirely, the group was central to this movement in Virginia and its female members largely conducted its work. ${ }^{73}$ Centered in Richmond, the group was founded in 1889 and focused on preserving the history of Virginia and the United States as one of aristocratic Anglo-

\footnotetext{
${ }^{70}$ Catherine W. Bishir, "Landmarks of Power: Building a Southern Past, 1885-1915," Southern Cultures Inaugural Issue (1993): 5-45.

${ }^{71}$ Brundage, "White Women and the Politics of Historical Memory," 114.

${ }^{72}$ Brundage, "White Women and the Politics of Historical Memory," 128.

73 James M. Lindgren, “'A Spirit That Fires the Imagination:' Historic Preservation and Cultural Regeneration in Virginia and New England, 1850-1950," in Giving Preservation a History: Histories of Historic Preservation in the United States, eds. Max Page and Randall Mason (New York: Routledge, 2004), 110.
} 
Saxon origin and of the South in general as a culturally legitimate place. ${ }^{74}$ Led by its female members, the group bought the Fredericksburg, Virginia home of Mary Washington, the mother of George Washington, in 1899 to save it from Northern developers. ${ }^{75}$ Just as Mount Vernon was revered as the domestic aspect that made Washington such a great civic leader, Mary Washington was praised for instilling domestic values in him initially. ${ }^{76}$

The movement in the South to readjust American memory was centered upon an elitism that echoed nationally in groups such as the DAR. This common point is one that united both the Southern and the national narratives in the 1893 Virginia Building and subsequent replicas: the domesticity recreated was not one in which African Americans were free, immigrants were present, or power was held by all white Americans. Rather it was a memory of elite, white idealized Colonial American history.

\footnotetext{
${ }^{74}$ Lindgren, Preserving the Old Dominion.

${ }^{75}$ Lindgren, Preserving the Old Domion, 207.

${ }^{76}$ Lindgren, Preserving the Old Dominion, 207.
} 


\section{CHAPTER II:}

\section{The Regional Narrative: Mount Vernon as Monument to New South Ideology}

The two narratives of the Virginia Building of 1893 - the regional and the national - were indicative of the double identity of late nineteenth-century Virginia as both Southern and as part of the United States. The story of the Virginia Building is exemplary of this duality. While Mount Vernon was an ideal symbol for union, those advocating it's use as the Virginia Building's model were steeped in the revisionist history that was currently dominating the collective memory of white, elitist Southerners; the Colonial American domesticity on display at the Virginia Building, therefore, was evidence of a memory that belonged only to a select group of the country's population. The dual narratives continued in Virginia's representation of its identity into the early twentieth century, lasting through the 1907 Jamestown Exposition in Norfolk, Virginia and the 1915 Panama-Pacific International Exposition in San Francisco, California.

\section{Role of the Virginia Building for the New South Virginia: The Necessity for the}

\section{Double Narrative}

The visibility made possible by the national and international scale of the World's Columbian Exposition made the participation - and success - of the Southern states imperative. ${ }^{1}$ Most Southern states, including Virginia, did not participate in the 1876 Centennial in Philadelphia as they were still actively recovering from both the Civil War and Reconstruction. The importance of the Southern states' participation at Chicago,

\footnotetext{
${ }^{1}$ The breadth of this thesis does not include a thorough examination of the World's Columbian Exposition as a whole. See James Gilbert, Neil Harris, Robert W. Rydell, and Wim de Wit, Grand Illusions: Chicago's World's Fair of 1893 (Chicago: Chicago Historical Society, 1993); Robert W. Rydell, All the World's a Fair: Visions of Empire at American International Expositions, 1876-1916 (Chicago: The University of Chicago Press, 1984).
} 
therefore, "[could not] be overestimated." and its representatives saw the fair as a means to promote the region's resources and financial opportunities. ${ }^{3}$ Some even saw the Exposition as a possibility to squelch prejudices about the South, a region which they would claim was more than an ignorant place which's people's "chief industry is stuffing ballot-boxes and shooting negroes."4

The inclusion of Virginia specifically was part of the early calls for Southern participation. Those who insisted on Virginia's representation wanted not only to promote resources and financial viability, but also to remind the union of her richness in history; such an emphasis was seen as a way to once again place the Southern state in prominence. Lieutenant Governor Major J. Hoge Tyler listed Virginia’s historical contributions to the union as one of the main reasons for participating in the event: "what would the history of our country be if the history of Virginia was left out? To have her left out of that grand gathering of the sisterhood of States would indeed be like the play of Hamlet without Hamlet." ${ }^{5}$ At a speech made at the fair's Virginia Day, Robert E. Lee nephew and former Virginia governor Fitzhugh Lee proclaimed: "Without Virginia there might have been no Illinois; without Illinois, no Chicago; without Chicago, perhaps, no World's Fair," specifically highlighting Virginia's importance to the event.

Though the Civil War was never far behind, the centrality of the state to the nation was a unifying concept. While the fair was understood as a moment of reconciliation, it was also an opportunity to nationally recognize that although they had

\footnotetext{
2 "The South and the World's Fair," The Times (Richmond), 14 May 1891, p. 4.

3 "A Question of Enterprise and Spirit," The Washington Post, 21 April 1891, p. 4.

4 "The South and the Fair," The Washington Post, 29 January 1891, p. 4.

${ }^{5}$ Lt. Governor Major J. Hoge Tyler quoted in "The Columbian Exposition," The Times (Richmond), 16 July 1891, p. 2.

${ }^{6}$ Fitzhugh Lee's speech quoted in "The Old Dominion: Virginia Day Celebrated at Chicago," Richmond Times, 10 August 1893, p. 1.
} 
been defeated, Virginia and the South still retained their dignity. Governor Philip W.

McKinney cited the fair as a chance to rectify Virginia's loss in the Civil War, clearly

linking the two events:

We are unable to develop [our natural resources] because of the great war between the States, which fell heaviest upon her, both during its progress and by its results... we should use this opportunity [the Exposition] to acquaint capital and enterprise with our resources and invite them to invest with us and come make a home with us and help to develop the advantages nature has so liberally given us. ${ }^{7}$

Lt. Governor Tyler indicated that the fair was very much about regaining the state's antebellum dignity, despite the temporal chasm between the two events:

Though she has passed through the crucial test of a [devastating] and ruinous war and has not yet laid aside mourning for her heroic sons, and though she may not be able to go wearing the gorgeous robes of her sisters and her daughters, she must go bearing in her hands samples of the robes she will yet wear and which will make her the envied of all the world. We must show that our Mother State is not dead; neither doth she sleep, and that, though oppressed, she is not discouraged, and though cast down, she is not forsaken. ${ }^{8}$

In this quotation, Tyler synthesized the concept central to the ideology of the New South: the past is essential to the present and the future. ${ }^{9}$ While Virginia was the "Mother" of the country, she was also a victim of the Civil War. This aspect of the state's history was as much a part of her present and future identity as that of the founding fathers. In Fitzhugh Lee's Virginia Day speech, he extended the memory of contemporary Virginia to the days of old, citing that after Virginia "brought forth a Washington" and “Washington's sword produced a republic...Grief and battle's crimson glare have dimmed her sweet eyes, while her blazoned banners have waved over many hard-fought

\footnotetext{
${ }^{7}$ Phillip W. McKinney, "Governor's Message," The Times (Richmond), 3 December 1891, p. 7.

${ }^{8}$ Tyler quoted in "The Columbian Exposition," p. 2.

${ }^{9}$ Paul M. Gaston, The New South Creed: A Study in Southern Mythmaking (Montgomery: NewSouth Books, 1970).
} 
fields." Yet Virginia would once again be central to the nation: "She has outsoared the shadow of her night. The star of a hopeful future is seen in the crown that binds the brow of the American Union."

Not all Virginians were as optimistic about the potential opportunities through participation in the fair. In a fall 1891 meeting of the volunteer corps the Army of Northern Virginia, members expressed that they did not wish to participate in the World's Columbian Exposition if it were decided that the Confederate flag could not be flown there: "[a General] was concerned he would never go to a place where the Confederate flag could not be raised...He had never seen an old Confederate soldier yet who was sorry that he had belonged to the Confederate army."11 Even after the fair opened, some Southerners boycotted the event. A commentator would observe of the Richmond population: "There are some very moderately intelligent folk right here in good, old Richmond who seem to think it a mark of superiority to affect indifference about this World's Fair at Chicago, ${ }^{, 12}$ indicating the attitude held by some Virginians and suggesting that their Southern allegiances encouraged their disdain of the event. These more extreme positions, coupled with the recognition on an official level of the fair as an opportunity for Virginia to reclaim her dignity, denote the impact of the memory of the Civil War on the state's participation in the World's Columbian Exposition.

These sentiments and aspirations were essential to the presentation of Mount Vernon as the Virginia Building, though its choice was also an obvious one. World's

\footnotetext{
${ }^{10}$ Fitzhugh Lee's speech quoted in "The Old Dominion," p. 1.

11 "Army of Northern Virginia," The Times (Richmond), 28 October 1891, p. 6. Field was nominated the next year to run for Vice President of the United States under the Populist Party. He was enlisted as a Southern sympathizer alongside Northern presidential candidate General James B. Weaver of Iowa. A Blue and Gray pavilion for the Exposition was also suggested as a means to promote union yet acknowledge the participation of both armies in the Civil War. The idea was deemed inappropriate and the concept scrapped. See "The Blue and Gray," The Washington Post, 3 June 1891, p. 5.

12 Jane Eldridge, "At the World's Fair," Richmond Times, 18 June 1893, p. 7.
} 
Columbian Exposition master architect Daniel Burnham advised states to build Colonial Revival structures to represent themselves and suggested replicating historic buildings central to the states' identities whenever possible. ${ }^{13}$ Virginia was not the only state to heed Burnham's advice, yet it did have the only state building that was such a complete and faithful reproduction of a specific domestic structure and setting. The Virginia Building served both the need to appease the region's wounded pride and to appear attractive to the national population. In response, no building was better suited to serve the national audience than the home of the country's first president. Mount Vernon signified Washington's role as a unifier, as well as his personal affiliations as a Southerner and particularly as a plantation owner. Continuity between the antebellum Southern identity and that of the New South legitimized the transgression of the Civil War and suggested that Virginia would have as clear of a role in the nation's future as it did in its past. ${ }^{14}$ Yet the history called upon as an example of present values was one in which the white elite held the power, recalling the contemporary desire for a return to conservative, racially segregated antebellum social conditions. ${ }^{15}$ At the same time that the proponents of the Virginia Building were crediting their state for producing the first representative government in the New World, ${ }^{16}$ Southern democrats were enacting racist voting restrictions and Jim Crow laws. ${ }^{17}$

\footnotetext{
${ }^{13}$ William B. Rhoads, The Colonial Revival (New York: Garland Publishing, 1977), 126. This was also cited as one of the hallmarks of the best state buildings of the fair in a review by architectural critics. See Montgomery Schuyler, "State Buildings at the Fair," Architectural Record 3 (July-September 1893): 56-8.

${ }^{14}$ James M. Lindgren, Preserving the Old Dominion: Historic Preservation and Virginia Traditionalism (Charlottesville: University Press of Virginia, 1993), 175.

${ }^{15}$ Lindgren, Preserving the Old Dominion, 180; Catherine W. Bishir, "Landmarks of Power: Building a Southern Past, 1885-1915," Southern Cultures, Inaugural Issue (1993): 5-45.

16 "The Old Dominion," pgs. 1-2.

${ }^{17}$ Richard Guy Wilson, The Colonial Revival House (New York: Harry N. Abrams, Inc., 2004), 50.
} 
The duality of this interpretation of history was present in the 1893 Mount Vernon replica's depiction of Colonial American domesticity: by focusing on the domestic memory of George Washington and America's past, Virginia was claiming that these values endured, despite regional transgressions. Concepts of antebellum hospitality were mixed with the new, symbolizing perseverance and superiority of antebellum domestic and social values. The story of the Virginia Building and its players place it within the movement led by the domestic sphere to reshape public memory of the South.

\section{"An Appeal to the Women of Virginia"}

While the "maiden efforts" of Virginia's participation in the World's Columbian Exposition were months of discussions by Virgiria politicians and an official meeting of businessmen in 1891, the project was also christened with a recognition and dependence upon the contribution of the state's women. ${ }^{18}$ At the resolution passed to establish the World's Fair Association of Virginia, it was resolved that "the women of Virginia be, and they are hereby, requested to render their sympathy and best efforts in this important work." $" 19$ The tone for the project was set: though men might support and represent it politically, the Virginia Building was essentially in the hands of women. This took on a greater dimension once it became clear that the state was unwilling to provide sufficient funding: the fundraising abilities of Southern women, made obvious through their successful campaigns for monuments to the Lost Cause, ${ }^{20}$ were now enlisted for a

\footnotetext{
18 "The Columbian Exposition," p. 2.

19 "The Columbian Expositon," p. 2.

${ }^{20}$ W. Fitzhugh Brundage, "'Woman's Hand and Deathless Love': White Women and the Commemorative Impulse in the New South," in Monuments to the Lost Cause: Women, Art, and the Landscapes of Southern Memory, eds. Cynthia Mills and Pamela A. Simpson (Knoxville: University of Tennessee Press, 2003), 6482.
} 
national effort. This play of events mirrors that of the Confederate monuments and even of the preservation of Mount Vernon itself: when the government was unable to step in or provide enough funding, elite white women raised the funds to make up the difference.

In November of 1891, the World's Fair Association of Virginia asked the state legislature for $\$ 100,000$ for the state's building and exhibits. ${ }^{21}$ By March 1892, the General

Assembly announced that they would appropriate no more than $\$ 25,000$, considered even then a "very low figure." 22 It was clear that additional help was needed; soon thereafter, it was obvious that the state's women were the ones to save the project. In May 1892, it was resolved that the women of Virginia were to "render every assistant to this laudable undertaking" and that to them be "delegated the patriotic duty of raising a fund to duplicate at Chicago, Mount Vernon, the home of Washington, as the Virginia Building." 23 Once again, women were given the task of shaping public memory because of the state government's unwillingness to do so.

Once it was established that Virginia would participate in the World's Columbian Exposition and that the state's female population would raise the money for it, the actual building and exhibit had to be planned and constructed. The concept for a replica of Mount Vernon at a world's fair had been previously proposed in commentary on the 1876 Centennial. Scribner's Monthly lamented what they perceived as a dearth of Colonial Revival buildings and specifically the absence of Mount Vernon at Philadelphia: "Both historically and artistically it would have been a good thing if... Virginia had received her

\footnotetext{
21 "Virginia Legislature," The Times (Richmond), 29 November 1891, p. 6.

22 "The Law-Makers' Work," The Times (Richmond), 6 March 1892, p. 5.

${ }^{23}$ World's Fair Board of Managers of Virginia, Organization, by-laws, plan of work, local and general of the Board of World's Fair Managers of Virginia including an Official Directory of the Board of Managers, Officers of the Board and Auxiliary Board, and of the Officers of the Columbian Exposition at Chicago (Richmond: 1892), meeting 11 May 1892 in Roanoke.
} 
guests in a lesser Mount Vernon house. ${ }^{94}$ Virginia did not receive any guests at the 1876 fair, but they would follow this advice in the World's Columbian Exposition seventeen years later.

The idea to include a replica of Mount Vernon as a foil to the "colossal structures of commerce, and the gorgeous palaces of art"25 of 1893 was first publicized by the Daughters of the American Revolution. In January of 1892, a nationwide committee of the Daughters of the American Revolution announced that they were planning on exhibiting "the manners, customs, and domestic life of the revolutionary or colonial period" in a house that would "probably be Mount Vernon, but its furnishings will be entirely from the contributions of the descendants of the Revolutionary heroes, or those persons having historic furniture." 26 A year earlier, the DAR had established contact with the Mount Vernon Ladies' Association suggesting that the two groups collaborate in their contribution to the Women's Building's "Retrospective Department;" it is unclear if they ever approached the MVLA formally about the intended replica. ${ }^{27}$ In the end, the DAR would not have a separate building, but only an exhibit in the Women's Building that included information about their accomplishments in preservation, finding the lost graves of American patriots, genealogical research, and relic collecting. ${ }^{28}$

\footnotetext{
24 "In and About the Fair," Scribner's Monthly 12, no. 5 (September 1876): 792.

${ }^{25}$ Senator John W. Daniel quoted in "The Old Dominion," p. 2.

26 "Grand Colonial Ball," The Washington Post, 10 January 1892, p. 9.

${ }^{27}$ Mount Vernon Ladies Association, 1891 Minutes of the Council of the Mount Vernon Ladies Association of the Union, May 1891 (New Haven: Tuttle, Morehouse, and Taylor, Printers, 1891).

${ }^{28}$ The DAR had been hesitant to participate in the Women's Building as they did not want their organization linked to groups that might be more undesirable or controversial (such as the suffragists). See Jeanne Madeline Weiman, The Fair Women: The Story of the Women's Building, World's Columbian Exposition, Chicago 1893 (Chicago: Academy Chicago, 1981), 504.
} 
By March 1892, Virginia had announced that they would instead be constructing the replica of Mount Vernon, ${ }^{29}$ linking the venture not only with the DAR, but also some of its major supporters. In fact, the DAR's Virginia members were chief contributors to the Virginia Building throughout its planning and construction; ${ }^{30}$ most likely, the same women were instrumental in suggesting and re-appropriating the idea from the national organization to the state building. Lucy Preston Beale, a prominent member of the DAR (1848-1928, Figure 21), was elected Lady Assistant to the World's Fair Board of Managers of Virginia and paid a salary for her work. ${ }^{31}$ Beale served as the central public figure for the Virginia Building's version of Colonial American domesticity while fitting the profile of a elite, white female advocate of the Lost Cause. In 1895, Beale would be elected honorary vice president of the DAR, a lifelong position that indicated her as a shining example for the association. Her genealogy made her an impeccable choice to fill the position: she directly descended from William Preston, a member of the House of Burgesses and James Patton Preston, a distinguished Army Colonel and an early nineteenth-century governor of Virginia. Yet Beale's ancestry was also deeply linked to the Confederacy: her father, William Ballard Preston, served as a Senator in the Confederate Congress as well as the Secretary of the Navy under President Zachary Taylor. ${ }^{32}$ Her family was regarded as one of the "oldest and wealthiest families" of

\footnotetext{
${ }^{29}$ Announced officially in the May 11, 1892 resolution calling for help from the state's women. See World's Fair Board of Managers of Virginia, Organization, by-laws, plan of work, local and general of the Board of World's Fair Managers of Virginia.

30 "Report by the Regent of Virginia," The American Monthly Magazine (The Official Magazine of the Daughters of the American Revolution) 2, no. 5 (May 1893). Credits the Old Dominion and Albemarle Chapters especially for their "noble work" in fundraising for the Virginia Building.

${ }^{31}$ World's Fair Board of Managers of Virginia, Organization, by-laws, plan of work, local and general of the Board of World's Fair Managers of Virginia.

${ }^{32}$ M. Sheffey-Peters, Mrs. Lucy Preston Beale: A Lady of Charming Manners and Diplomatic Address, Broadside, from The Daily Progress (Charlottesville, 14 January 1893), University of Virginia Special Collections, Charlottesville, Virginia.
} 
antebellum southwestern Virginia. ${ }^{33}$ After the United Daughters of the Confederacy (UDC) was founded in 1894, Beale became a member of her local chapter in Buchanan, Virginia, ${ }^{34}$ placing her clearly and officially as part of the organization that would most actively promote the memory of the Confederacy and the Lost Cause into the twentieth century. Beale's financial status and genealogical background ensured her position in both the national and Southern elite.

Sara Rice Pryor (1830-1912), vice president of the DAR and a Virginian, was also instrumental in the Virginia Building from the start, hosting a ball at White Sulphur Springs to raise money for the event shortly after the plan for the building was announced. ${ }^{35}$ Sara Pryor's husband, Roger A. Pryor, had fled to New York after the Civil War, though he never gave up on the myth of the Lost Cause. ${ }^{36}$ Sara Pryor had also been an incorporator of the APVA and served as the director of its New York branch, ${ }^{37}$ placing her front and center of both the national and regional female-driven elitist historical movements of the period. Sara Pryor was known as being especially snobbish, thereby conforming to the xenophobic tendencies of the DAR. ${ }^{38}$ Having women like Beale and Pryor that straddled both the national and regional white, elite societies as the most public female liaisons for the Virginia Building ensured the presence of the double narrative. In the end, it was the Southern hospitality of the women of the Virginia Building, and especially Beale, that made the venture such a huge success by providing a tangible link between domestic values of the past and the present.

\footnotetext{
${ }^{33}$ John S. Wise, The End of an Era (Boston: Houghton, Mifflin and Company, 1902), 218.

${ }^{34}$ Beale was a member of the Joseph W. Anderson Chapter \#1715 of Buchanan, Virginia. Barbara Dunn, the United Daughters of the Confederacy, electronic correspondence with the author, 22 February 2006.

35 "At White Sulphur Springs," The Washington Post, 24 July 1892.

${ }^{36}$ Lindgren, Preserving the Old Dominion, 46.

${ }^{37}$ Association for the Preservation of Virginia Antiques, Yearbook of the Association for the Preservation of Virginia Antiques, 1896.

${ }^{38}$ Martha Strayer, The D.A.R.: An Informal History (Washington, D.C.: Public Affairs Press, 1958), 48.
} 
Lucy Preston Beale met the task of appealing to the women of Virginia head-on. She acknowledged that Virginia had less funding than her "northern sisters" because they were still recovering from the Civil War, yet "poor though we be, let the women of Virginia, with a patriotic pride that cannot brook humiliation, tax themselves to signalize this anniversary of the New World's birth... ${ }^{39}$ Like her male counterparts, Beale saw the Exposition as a chance for the South to show a new face and that, "henceforth we shall wear the badge of pride or of shame. ${ }^{, 40}$ Though Mount Vernon would highlight the valor of domestic values of the past, Beale and her counterparts also sought to credit contemporary domestic values and accomplishments, linking the two:

We see that in other States, statistics are being gathered illustrative of woman' help in the moral and intellectual progress of the State, as well as her more material interests. Have Virginia women been idle in these noble fields?...Is there nothing in the way of the garden, the dairy, the orchard, or of domestic ordering that has received special impress at her hand $?^{41}$

Beale clearly placed emphasis on the domestic accomplishments of Virginia women. Her associations with the DAR, however, hint at the social limits of the domesticity that should be "impressed." Beale argued that Virginia should participate in the World's Columbian Exposition to show that "the beloved 'old land' life has indeed come again,",42 referring to the rebirth of the South's antebellum glory through the fabrication of the Lost Cause myth. Beale was fit for the job of carrying Virginia into the New South not only

\footnotetext{
${ }^{39}$ Lucy Preston Beale, An Address to the Women of Virginia (Virginia: Buchanan Standard Steam Print, 1890-93 (?)).

${ }^{40}$ Beale, An Address to the Women of Virginia.

${ }^{41}$ Beale, An Address to the Women of Virginia. Emphasis added.

${ }^{42}$ Beale, An Address to the Women of Virginia.
} 
as a "representative of [an] illustrious Southern family," ${ }^{, 43}$ but also a proponent of the values of the elitist, white South that would carry Virginia into the new millennium.

\section{The Commission: Male Proponents of the Old South Myth}

Edgerton Stewart Rogers (1860-1901, Figure 22) was announced as the architect for the Virginia Building in July of $1892 .{ }^{44}$ According to a period Richmond historian, he was appointed by the World's Fair commission "from among a very large number of competitors, and by unanimous vote. ${ }^{45}$ Rogers was born in Rome, Italy, in 1860 to the prominent American ex-patriot sculptor Randolph Rogers (1825-1892, Figure 23) and Richmond belle Rosa Ignatia Gibson Rogers. ${ }^{46}$ His education is a point of contention; different period sources claim that he attended the Ecole des Beaux Arts or the University of Rome before practicing architecture. ${ }^{47}$ Regardless, Rogers was trained in Europe and began practicing in his mother's hometown by 1887 or $1888 .^{48}$

Rogers's career in Richmond was solidified by the status of his mother, Rosa Gibson, in antebellum Richmond society. She was close to the Valentine family, ${ }^{49}$ a connection that certainly assured Rogers contacts in the Richmond art scene, as Edward

\footnotetext{
${ }^{43}$ M. Sheffey-Peters, "Mrs. Lucy Preston Beale," The Virginian, Women's Edition (28 November 1895): 16.

44 "The World's Fair," Richmond Dispatch, 29 July 1892, p. 3.

${ }^{45}$ Andrew Morrison, ed., The City on the James: Richmond, Virginia, The Chamber of Commerce Book (Richmond: George W. Engelhardt, 1893), 58.

${ }^{46}$ Rogers's obituary claimed that he was the first child born and registered as an American citizen in the United Italy. See "Capt. Edgerton S. Rogers," Inland Architect and News Record, 38, no. 4 (November 1901): 32 . Rogers was most likely named after one of the gentleman who funded his father's initial training in Florence between 1848 and 1850, Lycurgis Edgerton.

${ }^{47}$ See Morrison, The City on the James, 57 and "Capt. Edgerton Rogers Dead," The Times (Richmond), 20 August 1901.

${ }^{48}$ Differing accounts appear in Andrew Morrison, Richmond Virginia, and the New South (Richmond: George W. Englehardt \& Co., 1889) and Morrison, The City on the James.

${ }^{49}$ Millard F. Rogers, Jr., Randolph Rogers: American Sculptor in Rome (Cambridge: The University of Massachusetts Press, 1971), 83.
} 
Valentine was the city's most important sculptor. ${ }^{50}$ Even Rogers's professional obituary in the Inland Architect and News Record cites his mother as one of the catalysts behind his success: "Captain Rogers was identified with Richmond by the fact that his mother was Miss Rosa Gibson, a famous beauty and belle of the '50s." ${ }^{.51}$ His reputation as an architect was also undoubtedly aided by his father's work on the equestrian statue of George Washington on the grounds of the Virginia State House (see Figure 19). In fact, Rogers's father had received the highly coveted contract much to the credit of his wife as well; the upstanding social status of Gibson was cited as corroborating evidence of Rogers's artistic abilities to finish the monument after the death of sculptor Thomas Crawford. ${ }^{52}$ Edgerton Stewart Rogers would similarly be regarded as one of the "best known young architects of Richmond" $" 53$ and as "one of the best-known men about town," ${ }^{, 54}$ his professional reputation bolstered by his genealogical association to antebellum Richmond aristocracy.

Rogers also built his own contacts with Richmond high society, links that most likely granted him the prominent position as architect for the Virginia Building. Besides being connected to his father's monument to George Washington, an image central to the Confederacy, he was also a member of numerous elite Richmond institutions that were unquestionably part of the fabrication of the Lost Cause. His involvement in these

\footnotetext{
${ }^{50}$ Rogers's personal relationship with Edward Valentine is assured by his election as a lifetime member of the Valentine Museum and donations of books he made to the organization. His father and Valentine could also have been personally acquainted, as both were prominent American sculptors of the same period.

51 "Capt. Edgerton S. Rogers," 32.

${ }^{52}$ In a letter written days before Rogers signed the contract for the statue, Anna Cora Ritchie wrote to Henry Theodore Tuckerman: "His recent marriage with one of our ... most popular Virginia girls is the occasion of his visit to Richmond. She has lots of friends and influential ones..." Anna Cora Ritchie to Henry Theodore Tuckerman, 15 December 1857, Anna Cora Ritchie Papers, Small Special Collections, The University of Virginia Library, Charlottesville, Virginia.

53 "Capt. Edgerton Rogers Dead."

54 "Captain Rogers Dead," The Richmond Dispatch, 20 August 1901.

${ }^{56}$ John A. Cutchins, A Famous Command: The Richmond Light Infantry Blues (Richmond: Garrett and Massie, 1974).
} 
groups place Rogers in the same realm of the ladies who were crafting the myth, despite the fact that such contributions made by the male population were most often not as public and were more socially oriented. Rogers earned his title of "Captain" from his position in the Ashby Light Horse Guard, a militia group of young privileged men that incorporated with Richmond's Light Infantry Blues in 1894. The Light Infantry Blues had served in the Civil War and regrouped after Reconstruction, meeting in the home of John S. Wise to form an independent infantry company separate from the larger Virginia Reserves. ${ }^{56}$ Wise had been a distinguished young Confederate soldier who had moved to New York after being defeated by Fitzhugh Lee in the Virginia governor's race, though he "never surrendered a particle of this loyalty to the cause of the South." W7 Wise's wife, Evelyn Douglas Wise, would be central to the Virginia Building alongside Pryor and Beale: she was elected United States Lady Manager of the Auxiliary Board of the World's Fair Board of Managers of Virginia. The Light Infantry Blues functioned as more of a social club for prominent Richmond residents than as an active militia. Their goal was to recreate the brotherhood of volunteer Confederate soldiers, going so far as to contract uniforms that replicated those worn by the battalion in the Civil War. ${ }^{58}$ They also led military participation in the city's early Civil War memorials: their flag was christened at the Monument Avenue Robert E. Lee Monument unveiling in May 1890 and members served as escorts for the APVA women traveling to the Mary Washington

\footnotetext{
${ }^{57}$ Jennings Cropper Wise, Col. John Wise of England and Virginia (1617-1965): His Ancestors and Descendants (Richmond: The Bell Book and Stationary Co., Inc., 1918). Wise also published a book in which he described himself at the end of the Civil War: "I was dead...My beloved State of Virginia was dismembered, and a new State had been erected out of a part of her, against her will." John S. Wise, The End of An Era (Boston: Houghton, Mifflin and Company, 1902), 462.

${ }^{58}$ Cutchins, A Famous Command, 179.
} 
Memorial. In an 1882 speech at a Light Infantry Blues banquet, member Thomas Nelson Page would synthesize the purpose of the club:

But thank God, the spirit of indifference for the old things which I love, and which are but worth loving, and which make the men of the present worthy of the past, has not killed out this grand old company which is sanctified to us by a hundred years of American history which are worth a thousand years of any other history. ${ }^{59}$

These sentiments are indicative of the sense of superiority in the mindset of the white, elite South in the years following the Civil War, as well as their reverence for a by-gone past. The group even participated in national events, taking their prejudices to the 1897 dedication of Ulysses S. Grant's tomb in New York City. When the major of the African American battalion at the event was of a higher rank than the white Light Infantry Blues major adjoining him, the black major deferred to the white, avoiding an "awkward" and "potentially embarrassing situation." $" 60$ When Rogers joined the Ashby Light Horse Guard in 1892 , he pronounced his sympathy to this ideology.

Along with many of the members of the Ashby Light Horse Guard and of the Light Infantry Blues, Rogers was also a member of the Westmoreland Club, a group that claimed to have "preserved the social standards of the old South."61 The organization was founded in 1877, consisting of "a number of Confederate officers...finding inexhaustible interest in discussing the battles from which they had just come." ${ }^{62}$ It was an elite institution; the annual dues were steep, ${ }^{63}$ and membership depended upon nomination and election by existing members of the club. Its connections with the Lost

\footnotetext{
59 Thomas Nelson Page on 28 June 1882, quoted in Cutchins, A Famous Command, 187.

${ }^{60}$ Cutchins, A Famous Command, 199.

61 "Fiftieth Anniversary, January 29, 1927, Westmoreland Club, Richmond, Virginia." The Library of Virginia, Richmond, Virginia.

${ }^{62}$ Westmoreland Club, The Constitution, By-Laws and House Rules of the Westmoreland Club of Richmond, VA (Richmond: The Bell Book and Stationery Co., 1909), 5.

${ }^{63} \$ 25.00$ in 1877 , an amount that is roughly equal to $\$ 433.00$ today.
} 
Cause were underscored by the content of the art collection hung in the impressive Grace Street clubhouse (Figure 24$)::^{64}$ almost $40 \%$ of all of the fifty-eight portraits in the club were of Confederate military men. ${ }^{65}$ Another $22 \%$ were images of George Washington. ${ }^{66}$ One of the most prominently displayed portraits was that of President of the Confederacy Jefferson Davis by William Garl Browne, which hung in the front parlor. Even the name of the club referred to the importance of both Confederate and Revolutionary history and the continuity between the two: "Westmoreland" was chosen to reference the name of the county in which both Robert E. Lee and George Washington were born. ${ }^{67}$ The organization also boasted a willow tree in the front yard of the clubhouse that was said to have grown from a slip brought from Mount Vernon by the house's original owners. ${ }^{68}$ The flag of the society also reflected their allegiances to the Lost Cause in its striking formal similarity to the flag of the Confederacy (Figures 25 and 26).

The Westmoreland Club's roster included many of the Richmond residents associated with organizing the Virginia Building, suggesting another place of origin for Edgerton Stewart Rogers's commission. In 1893, Rogers was listed as a member of the Westmoreland Club. In addition were Col. A. S. Buford, President of the World's Fair Managers of Virginia, Thomas Nelson Page, and Sara Rice Pryor's husband, Roger Pryor. Major James Dooley, owner of the grand Richmond home of Maymont (Figure 27) and Rogers's only other significant commission, was also a member. Lucy Preston

\footnotetext{
${ }^{64}$ The building was demolished in 1937 after the organization was incorporated with the Commonwealth Club. See Marylou Rhodes, Landmarks of Richmond: Places to Know and See in the Nation's Most Historic City (Richmond: Garrett and Massie, 1938), 135-37.

${ }^{65}$ Most of the paintings in the club were originally owned by Virginia Historical Society, who had previously held their own club meetings in the building. Those remaining were chosen by one of the club's founding members, Edward Valentine.

${ }^{66}$ These statistics were gathered by the author from a list of the artwork hung in the Westmoreland Club in 1909 according to list in Westmoreland Club, The Constitution, By-Laws and House Rules.

67 "Fiftieth Anniversary, January 29, 1927, Westmoreland Club, Richmond, Virginia."

${ }^{68}$ Westmoreland Club, The Constitution, By-Laws and House Rules, 32.
} 
Beale's brother in-law, A. L. Boulware, was a member of the Westmoreland Club, as was Fitzhugh Lee. ${ }^{69}$ These men and the organizations to which they collectively belonged served as a counterpoint to the feminine volunteer societies created to memorialize the same concepts: the superiority and social import of the elite, white South and the continuance of these social ideals from the Colonial period, through the Civil War, and into the future of Virginia.

Rogers would become directly linked to a specifically Confederate memorial organization after the Virginia Building through his second-place entry in the 1896 competition for the Jefferson Davis Monument (Figure 28). His classical design was chosen by the Davis Monument Committee of the United Confederate Veterans, and featured a pantheon-like enclosure for a giant statue of Davis, complete with a Confederate battle flag in mosaic on the interior of the dome. ${ }^{70}$ A contemporary newspaper account described the effort:

It was the intention of Captain Rogers to embody in his plans, not only the proportions of a monument, that would be fitting in beauty and dignity to commemorate the leader of the Lost Cause, but also to symbolize in it the splendid story of the life of a patriot, crowned with all the civic virtues, beloved by the people, and even in the darkness of defeat, bright with the luster of virtue and self-sacrifice. ${ }^{71}$

Edgerton Stewart Rogers's effort and involvement in such a monument clearly dedicated to the Lost Cause myth suggests his continued sympathy with the movement.

\footnotetext{
${ }^{69}$ Richmond Elite Directory (Blue Book), (Richmond: J. H. Hill Printing Co., 1893).

70 "Adopt the Design," The Richmond Dispatch, 30 June 1896, p. 1.

71 "Adopt the Design," p. 1.
} 


\section{The Memory of Colonial American Domesticity - Recreated}

In July of 1892, the plan for the Virginia Building was described in the

\section{Washington Post:}

Mount Vernon at Chicago means the house of home-life, hospitable welcome, latch string hanging out. Virginia kitchen, bacon beaten biscuit, servants in attendance, and all the other belongings of that ancient mansion, where the Father of His Country dispensed hospitality. ${ }^{72}$

This description enforces the primary objective of the exhibit: to replicate Washington's domestic world, complete with housekeeper, slaves (called servants) and even suggesting a culinary component. ${ }^{73}$ The Virginia Building would live up to this preliminary sketch in that contemporaries in every way understood the exhibit as a living recreation of Mount Vernon, linking the hospitality of days gone by with present domestic courtesies. Although most of the state buildings at the fair operated as beacons of hospitality, Virginia's Mount Vernon was the only one that could boast a "faithful" copy of a particular home. Yet this exhibit was more than just the supposed reincarnation of Colonial American domestic values, it also emphasized the particularly regional aspects of the building and its owners' histories.

The Board of World's Fair Managers of Virginia began discussing the possibility of procuring a model of Mount Vernon and borrowing relics for the Virginia Building from the MVLA in early $1892 .^{74}$ By June of the same year, the MVLA had agreed to provide a model so that the Virginia Building could be faithfully copied, but refused to

\footnotetext{
72 "Mount Vernon at Chicago," The Washington Post, 21 July 1892, p. 7.

${ }^{73}$ There is no evidence that the Virginia Building acted as a cafeteria. It is possible that in early projections for the endeavor, this component was suggested in response to the success of the New England Kitchens at antebellum sanitary fairs or the 1876 Centennial.

${ }^{74}$ Mount Vernon Ladies Association, 1892 Minutes of the Council of Mount Vernon Ladies Association of the Union, June 1892 (New Haven: Tuttle, Morehouse, and Taylor, Printers, 1892), 34.
} 
lend relics on the grounds that they were too precious. ${ }^{75}$ By February 1893, the work on the main building of the replica was nearly complete, ${ }^{76}$ suggesting that sometime in the summer of fall of 1892 , Rogers went to Mount Vernon to make measured drawings for the Virginia Building. ${ }^{77}$ In April of 1893, shortly before the World's Columbian Exposition was to open, Rogers published drawings of the Virginia Building in the Inland Architect and News Record in which the titles of Mount Vernon and the Virginia Building are used interchangeably (Figure 29). ${ }^{78}$ Rogers's Mount Vernon imitated the floor plan of the original (see Figure 3), reproducing such spaces as the entrance halls, the banquet hall (used as the reception room), the library, and the upstairs bedrooms.

Presumably, the kitchen and servants hall connected by portico hyphens to either side of the main mansion of the original Mount Vernon were also included in the replica, as indicated by photographs (see Figures 4 and 5-7). A published letter by the Executive Business Commissioner of the World's Fair Managers of Virginia to President Colonel A. S. Buford from February of 1893 states that the contractor "will... begin the work on the annex buildings at once. The main building is rapidly progressing to completion," confirming that there were subsidiary buildings. ${ }^{80}$ It is unclear whether these spaces were used as offices or as an extension of the main building's exhibit spaces.

\footnotetext{
${ }^{75}$ Mount Vernon Ladies Association, 1892 Minutes.

76 "World's Fair Notes," Richmond Dispatch, 2 February 1893, p. 4.

${ }^{77}$ The only documented visit made by the Board of World's Fair Managers of Virginia to Mount Vernon was in early 1893. See Mount Vernon Ladies Association, 1893 Minutes of the Council of the Mount Vernon Ladies Association of the Union, May 1893 (New Haven: Tuttle, Morehouse, and Taylor, Printers, 1893), 37.

78 "Details: sketches by Edgerton S. Rogers, archt.," Inland Architect and News Record 21 (April 1893): pl. fol. p. 42. The two titles were often used interchangeably in official or publicity literature as well; often the Virginia Building was called "The Mount Vernon Building."

80 "Virginia at Chicago," Richmond Dispatch, 10 February 1893, p. 3.
} 
The interior details of Washington's home were faithfully copied, as Rogers's published designs for the walls in the library show attempts to replicate wall paneling and frieze decorations. A historian of the fair would describe this level of attention: "The carved mantels and wood trimmings were exact facsimiles, as well as the windows, with small panes and sashes fastened with wooden buttons."81 Chicagoan William B. Holtzclaw acted as the building's contractor, ${ }^{82}$ and considerable thought was given to making the building fireproof in order to ensure the safety of its contents. ${ }^{83}$ Before the building opened, Mount Vernon Superintendent Harrison H. Dodge deemed the replica "very credible," ${ }^{94}$ setting the tone for critical reviews of the Virginia Building.

Also central to the liaisons between the real and the replicated Mount Vernon was Lucy Preston Beale, ${ }^{85}$ who was described on a visit to Washington's home by another visitor:

The central figure of another circle is Mrs. B., whose patrician face and distinguished bearing prove her the well chosen representative of Virginian's fair daughters at the Columbian Exposition. She is visiting the place to examine the house, furniture, etc., with a view to fitting up the Virginia building after the similitude of Mount Vernon. ${ }^{86}$

Both Beale and Rogers, therefore, were essential to ensuring that the Virginia Building was indeed a faithful replica of the original. Even the way in which the house was

\footnotetext{
${ }^{81}$ Rossiter Johnson, ed., A History of the World's Columbian Exposition (New York: D. Appleton and Company, 1897), 485.

82 "World's Fair News Notes," Richmond Dispatch, 4 March 1893, p. 3.

83 "The World's Fair," Richmond Dispatch, 29 July 1892, p. 3.

${ }^{84}$ Mount Vernon Ladies Association, 1893 Minutes of the Council, 37.

${ }^{85}$ Beale was also made supervisor of the Virginia Room at Mount Vernon by Virginia Vice-Regent Emma R. Ball. Mount Vernon Ladies Association, 1893 Minutes.

${ }^{86}$ J. A. G., "Mount Vernon and the Mount Vernon Association," The American Monthly Magazine (The Official Magazine of the Daughters of the American Revolution) 2, no. 5 (May 1893): 530. The description is of a visit to Mount Vernon made by the article's author in June 1892. It was most likely published in May of 1893 to correspond to the highly publicized opening of the World's Columbian Exposition and hence, the Virginia Building.
} 
situated on its site in Chicago resembled the way that the yard of Mount Vernon slopes to the Potomac. ${ }^{87}$

Unlike the Massachusetts building that changed the look of its inspiration, the Hancock House, in order to appear more "civic" and, therefore, to better adapt to the prevailing architectural styles of the fair, ${ }^{88}$ the Virginia Building was first and foremost a copy of a famous domestic structure. The efforts of the Board and its architects to create a "[s]tate building which should accurately represent Mount Vernon," "89 were not in vain; contemporary critics and observers understood the building as an exact replica. Benjamin Cummings Truman's comprehensive history of the fair would describe the Virginia building as "not only an exact representation in every particular of the old Mount Vernon structure, but everything within it is also of the same character. Nothing modern is seen in the building, except the people..." ${ }^{90}$ In his account of the World's Columbian Exposition, Virginian R. Beverly Eggleston would exclaim: "How delighted was a Virginian to have his eye fall upon Mount Vernon exactly reproduced." 91

Besides the replicated architecture, the exhibits that filled the building ensured the reproduction quality of the Virginia Building. The building did not have modern interior spaces; its rooms were reserved for exhibits that would imitate the domestic qualities of the original and compliment the interior decoration. Period furniture and bric-a-brac filled the house; many of these "relics" belonged to the Virginia-born founding fathers or

\footnotetext{
${ }^{87}$ Susan Schoelwer Prendergast, "Curious Relics and Quaint Scenes: The Colonial Revival at Chicago's Great Fair," in The Colonial Revival in America, ed. Alan Axelrod (New York: WW Norton \& Company, 1985), 189.

${ }^{88}$ Rhoads, The Colonial Revival, 127.

${ }^{89}$ World's Fair Board of Managers of Virginia, Proceedings of Meeting held at Roanoke, Virginia, May 10 , 11, and 12, 1892 (Richmond: 1892), 2.

${ }^{90}$ Benjamin Cummings Truman, History of the World's Fair: Being a Complete Description of the World's Columbian Exposition from its Inception (Chicago, Monarch Book Co., 1893), 474.

${ }^{91}$ R. Beverly Eggleston, Four Days at Chicago: Descriptive and Historical (Richmond: Whittet and Shepperson, 1901).
} 
Washington himself (Figure 30). They included a cloak given to Washington during his presidency from a European head of state, a reproduction of the bed and bedclothes in which he died, and Martha Washington's tea caddy. ${ }^{92}$ Because not enough "authentic" relics could be collected to fill the structure, some rooms had to be closed. ${ }^{93}$ Rather than sacrifice the illusion of reproduction, the Virginia building remained sparse.

Not all of the relics in the Virginia Building were of the Colonial period, however. Suited to the intention of its proponents to connect the antebellum, Civil War, and contemporary histories of Virginia, the building also exhibited Confederate relics. Included were whiskey flasks and a mahogany table owned by Jefferson Davis, a statue of Robert E. Lee, photographs of Confederate money, and a photograph of Confederate General Stonewall Jackson. In addition, many of the books in the library of Virginia authors were about Civil War history or biographies of Confederate heroes. Prominent Virginia families donated most of these relics, John S. Wise being particularly well represented. The inclusion of relics - whether pertaining to regional or national history reinforced the concept that the sacred quality of memory was preserved in the domestic sphere. ${ }^{94}$ That the exhibit included relics from both the Colonial and the Civil War eras was indicative not only of the way in which the two memories were intertwined in Southern memory, but that the memory being displayed was specific to those in whose hands it rested: the white elite that organized the event and contributed objects to its displays.

\footnotetext{
${ }^{92}$ For a complete list of all of the relics and objects included in the building's exhibits, see John Samuel Apperson, Communication from the Governor Inclosing the Report of the World's Fair Commissioners Senate Doc. 16, 7 November 1893 (Richmond: 1893).

${ }^{93}$ Karal Ann Marling, George Washington Slept Here: Colonial Revivals and American Culture, $1876-$ 1986 (Cambridge: Harvard University Press, 1988), 91.

${ }^{94}$ Michael Kammen, Mystic Chords of Memory: The Transformation of Tradition in American Culture (New York: Alfred A. Knopf, 1991), 107.
} 
Also integral to the Virginia Building was the presence of Lucy Preston Beale, who was known throughout her life for embodying the hospitality that was so central to the link between antebellum and contemporary Southern domesticity. In a 1896 women's edition of the periodical The Virginian edited by Beale, Virginia women are emphasized as domestic paragons: "In contrast with other women of our own country...the repose-the poise of manner-claimed as the Virginia Woman's peculiar characteristic...the Virginia Woman is Queen in the 'Old Dominion.' Home is her Kingdom." Beale's social status and demeanor made her the ultimate Virginia woman and the ideal person to conduct the daily business of the Virginia Building. She was officially credited with its success after the fair had ended:

...whatever social advantages, attentions and comforts Virginians have received at the Mt. Vernon...the credit is largely due to the thoughtful and genial hospitality of the lady assistant, Mrs. William R. Beale, and it is no risk to venture the remark that she will be most kindly remembered by the hundreds of visitors who have seen the fair and had the privilege of meeting her at the Virginia State Building. ${ }^{96}$

If the Virginia Building was a real, working house, then Beale was its matriarch and her presence was duly noted. Her contribution would also be described:

To Mrs. Beale's individual popularity and wide influence, was largely owing whatever measure of success was conceded to Virginia, both in the exhibit of relics and the entertainment of guests at Mount Vernon. With insufficient appropriations and contributed funds to draw upon she did all that lay in her power to uphold the dignity, to maintain the credit and honor of her State... ${ }^{97}$

\footnotetext{
${ }^{95}$ Callaway Spottiswood Moore, The Virginian, Woman's Edition (28 November 1895): 9-10.

${ }^{96}$ John Samuel Apperson, Communication from the Governor Inclosing the Report of the World's Fair Commissioners. Senate Doc 16, 7 November 1893 (Richmond (?): 1893).

${ }^{97}$ M. Sheffey-Peters, "Mrs. Lucy Preston Beale," 17.
} 
Beale was, therefore, understood as the "embodiment of true Virginia courtesy and charm," ${ }^{998}$ fulfilling the sentiment that the Virginia Building was truly a Southern home in that it represented lasting Southern domestic values. Another admirer would remark that she was "the presiding genius, welcoming guests and dispensing the hospitality for which that old commonwealth is proverbial." ${ }^{99}$ Her status as a particularly fitting example was indicated by an 1895 baking powder advertisement (Figures 31 and 32). In the same publication in which Beale is praised for her work in both the 1893 and subsequent 1895 expositions, she is pronouncing her role as a domestic spokesperson as she "cheerfully recommends [the product] to all housekeepers." "100 Apparently, company executives understood her potential influence on their public, enrolling her endorsement for a household product.

Yet Beale's daily presence at the Virginia Building was not the only human component that assured its realization as a living domestic structure. The building also had a staff of African American employees, suggesting Beale as the mistress of the house and her helpers as slaves. This analogy did not elude contemporaries, as one would observe: "for the attendants in the building old Virginia negroes, and undertakes to represent in every particular an old Virginia home of the Colonial period." ${ }^{101}$ By reverting to the eighteenth-century role of African Americans and denying the struggle over the institution of slavery in the Civil War, the Virginia Building was applying the

\footnotetext{
98 "Lucy Preston Beale, ex -'64," The Hollins Alumnae Quarterly 3, no. 2 (July 1928): 19.

99 J. A. G., "Mount Vernon and the Mount Vernon Association," The American Monthly Magazine (The Official Magazine of the Daughters of the American Revolution) 2, no. 5 (May 1893): 530.

${ }^{100}$ Advertisement for Royal Baking Powder. The Virginian, Woman's Edition (28 November 1895): back of front cover.

${ }^{101}$ Truman, History of the World's Fair, 474. This description also yields a comparison to the nearby Midway, where Africans and other native peoples were put on display in their "native" habitats. See Robert W. Rydell, "A Cultural Frankenstein? The Chicago World's Columbian Exposition of 1893," in American Architectural History: A Contemporary Reader, ed. Keith L. Eggener (London: Routledge, 2004), 249-266.
} 
Lost Cause myth; in order for the elite, white South to relinquish itself, it had to deny the brutality and inhumanity of slavery. Connecting it to the universally revered founding father was certainly an effective means to do so. By reinforcing the antebellum social hierarchies through the replication of Southern Colonial domestic architecture and lifestyle, the Virginia Building's proponents made their participation in the Lost Cause blatant. $^{102}$ The memory of Colonial American domesticity still lay solely in the hands of those who had struggled to hold onto social power - the elite white - in the Confederate South.

Despite the allegiance to the reconciliation of elitist, white Southern memory, the Virginia Building was tremendously popular at the World's Columbian Exposition. ${ }^{103}$ Its guest book was full months before the end of the fair, ${ }^{104}$ and the fair's tram often emptied at the adjacent "Mount Vernon" stop. ${ }^{105}$ Though the regional narrative was present for those that created the Virginia Building and perhaps for some of its Southern visitors, the overwhelming number of world's fair-goers were drawn to the exhibit's national associations and to the pure novelty of its completely recreated domesticity. The regional narrative did not escape many Virginians, however, as Mount Vernon replicas of the first decades of the twentieth century continued to employ similar tactics and ideologies.

\footnotetext{
${ }^{102}$ See Bishir, "Landmarks of Power: Building a Southern Past."

${ }^{103}$ Schoelwer, "Curious Relics and Quaint Scenes," 189.

${ }^{104}$ World's Fair Managers of Virginia, Visitor's Register, Mount Vernon Building, World's Fair. Library of Virginia, Richmond, Virginia. The Register is officially dated from May 25 through December 9, 1893, though the last entry was squeezed in on September 29, 1893.

${ }^{105}$ The Dream City: A Portfolio of Photographic Views of the World's Columbian Exposition (St. Louis: N. D. Thompson Publishing Co., 1893).
} 


\section{Memory on Native Soil: The Jamestown Exposition}

Although the 1907 Jamestown Ter-Centennial Exposition held in Norfolk, Virginia, did not boast a replica of Mount Vernon, it is noteworthy in that it was an international forum for the Southern elite to present their collective memory on their own soil. $^{106}$ This fair focused on the seminal events of Anglo-Saxon American history, ${ }^{107}$ and emphasized only the regional narrative introduced in 1893 . The architectural style of the fair - the Southern Colonial Revival - reinforced this public memory, serving as a sign of the New South while reiterating the glories and hierarchies of the Old South. While the 1893 Mount Vernon Building had utilized a double narrative to serve both concepts of national and Southern identities, the Jamestown Exposition grounds and architecture suggested only a socially limited regional identity and memory of American domestic values. What resulted was a mix of memories that combined the Revolutionary and Colonial eras with the landing of Jamestown and the Civil War as a continuous chain of events that confirmed the primacy of the white, Southern elite.

By 1907, the female memorial clubs and organizations that had been in their infancy at the 1893 Virginia Building were in full swing; they confidently displayed the limited definition of Southern domesticity evoked by the 1893 Virginia Building. The Virginia Chapter of the United Daughters of the Confederacy were represented by "an exact facsimilie" of Beauvoir, ${ }^{108}$ the last home of Jefferson Davis in Biloxi, Mississippi, a

\footnotetext{
${ }^{106}$ For an account of the 1907 Jamestown Ter-Centennial Exposition, see Carl Abbott, "Norfolk in the New Century: The Jamestown Exposition and Urban Boosterism," The Virginia Magazine of History and Biography 85, no. 1 (January 1977): 86-96; Robert T. Taylor, "The Jamestown Tercentennial Exposition of 1907," The Virginia Magazine of History and Biography 65, no. 2 (April 1957): 169-208; Lindgren, Preserving the Old Dominion, 122-29.

${ }^{107}$ Lindgren, Preserving the Old Dominion, 123.

${ }^{108}$ Charles R. Keiley, ed., The Official Blue Book of the Jamestown Ter-centennial Exposition, A. D. 1907 (Norfolk: The Colonial Publishing Company, 1909), 388, emphasis in original.
} 
blatant symbol of Confederate power and elitism (Figures 33). The goal of the group and the purpose of its building was explained in the Official Blue Book of the fair:

It was not for the purpose of conducting a war museum that the Daughters erected their home. 'The Old Dominion' did not alone cause the Virginia Division to memorialize the era to whose traditions they are devoted. There was a larger and wider motive underlying the enterprise - to dispense to visitors such hospitality to 'The Lost Cause' its commemorators were eager to extend a peaceful welcome in 1907 , no less exultant than the war welcome of Virginia in $1861 \ldots$ it was thought that the whole south would desire to unite in honoring the only president of the Confederacy. ${ }^{109}$

The UDC Building, therefore, aimed to be a link between the Old South and the New South through domestic values such as hospitality; just as George Washington's home had served this function in 1893, Davis's would in 1907. The building functioned as a place to unite the white, exclusive South, as the Southern African American population, for example, would surely not want to be represented by a copy of the president of the Confederacy's home. That it focused on the domestic values of the antebellum South reinforced the motives behind the 1893 Virginia Building; the supposed survival of these qualities in the New South mentality presented a cause that was not entirely lost and a region that had retained its domestic values despite a crushing defeat.

This theme of perseverance in the domestic sphere was succinctly presented at the Exposition's Virginia Building (Figures 34). Virginia governor Claude A. Swanson would present a memory of the state on Virginia Day that confirmed this process of rehabilitation of Southern identity and emphasis on domesticity: ${ }^{110}$

Virginia furnished a magnificent and suitable stage for the cavalier to unfold the drama of his new destiny. Soft and sweet as the memories of buried love will ever lie in our hearts the old colonial homes and plantations of Virginia, embowered in forests, shrubbery and flowers,

\footnotetext{
${ }^{109}$ Keiley, The Official Blue Book, 388.

${ }^{110}$ Swanson was also a member of the Westmoreland Club.
} 
bright with joyous romantic life, ruled by superb women and noble men. The history of the Old Virginia from Jamestown to Appomattox is the history of a great and glorious people, ever to be noted in story and in song. 111

In this one statement, Swanson synthesizes the memory created and confirmed by the efforts of the fair: a romantic view of an Old Southern state whose history is marked by Jamestown at its inauguration and the Civil War at its climax. The cavalier is still the representative, an actor of bygone days reborn in the present. The architecture of the Virginia Building epitomized these statements in all of its Southern Colonial Revival glory. Marked by giant white columns, prominent chimneys and dormers, and a doubleheight temple-front portico, the Virginia Building confirmed the combination of Southern elitism and the rehabilitation of the Southern image through Colonial architecture. ${ }^{112}$ Although replicating a famous Virginia residence such as Mount Vernon was considered, the committee chose to portray an "ideal old Colonial home, the type of the period."113 The goal at the Jamestown Exposition was not to present history as it was, but to blatantly construct an idealized memory of the past.

Much like most of the other state buildings at the fair (Figure 35), the Virginia Building did not hold exhibits and was instead intended as a place of rest for the fair's visitors or as a venue for official receptions. ${ }^{114}$ The structure was filled with furniture loaned by prominent Virginia families and simulated an idealized home of an equally elite imaginary society (Figures 36 and 37). The propagandistic Official Blue Book would describe the interior as the "inheritance of an age and a civilization that have

\footnotetext{
${ }^{111}$ Claude A. Swanson, Address of Governor Swanson on 'Virginia Day' at the Jamestown Exposition, 1907 (Richmond: D. Bottom, 1908).

${ }_{112}$ Bishir, "Landmarks of Power: Building a Southern Past."

${ }^{113}$ Keiley, The Official Blue Book, 338. The Virginia Building committee included members of the APVA and was enthusiastically endorsed by Governor Swanson, a "friend" of the Virginia Chapter of the Daughters of the Confederacy.

${ }^{114}$ The state exhibits were held in a separate building.
} 
passed," 115 signaling the nostalgia and romanticizing that dominated the domestic vision. The goal, much like the UDC's replica of Jefferson Davis's home, was intended to convey an "effect of homelike comfort" "116 that would confirm the repose and beauty of Southern society. Once again, Lucy Preston Beale was exemplary of these qualities and served as one of the building's hostesses. Through a combination of the memories of the Colonial and the present achieved by the idealized architecture of its building, Virginia was rehabilitating its Civil War defeat to re-empower Southern elite society. By "reminding" fair visitors of Virginia's long-standing history of domestic values, including hospitality, the architecture of the Virginia Building was central to the creation and confirmation of the public memory promoted by the Jamestown Exposition and echoed its Mount Vernon predecessor.

\section{Mount Vernon Goes West: The Panama-Pacific International Exposition Replica}

The Virginia Building at the 1915 Panama-Pacific Exposition in San Francisco, California, was again a replica of Mount Vernon (Figures 38-40). ${ }^{117}$ Designed and overseen by Richmond architect Charles Kirkpatrick Bryant (1867-1933, Figure 41), the building was a direct descendant of the 1893 replica. Bryant would have been acquainted with Edgerton Stewart Rogers before the young architect's untimely death in 1901 as Bryant's early partner, Benjamin West Poindexter, ${ }^{118}$ was a good friend of Rogers's.

\footnotetext{
${ }^{115}$ Keiley, The Official Blue Book, 340.

${ }^{116}$ Keiley, Official Blue Book, 339.

${ }^{117}$ For an account of the Panama-Pacific International Exposition, see Ben Macomber, The Jewel City: Its Planning and Achievement; Its Architecture, Sculpture, Symbolism, and Music; Its Gardens, Palaces, and Exhibits (San Francisco: John H. Williams, 1915).

${ }^{118}$ Bryant and Poindexter began their partnership in 1892. For a discussion of Poindexter's work and his partnership with Bryant, see Kerri Elizabeth Culhane, "The Fifth Avenue of Richmond": The Development of the 800 and 900 Blocks of West Franklin Street, Richmond, Virginia, 1855-1925" (master's thesis, Virginia Commonwealth University, 1997); Morrison, The City on the James, 58.
} 
Poindexter had served with Rogers in the Ashby Light Horse Guard and Bryant would later join the same organization. ${ }^{119}$ In Rogers's brief 1899 last will and testament, he bequeathed all of his "professional books" and office furniture to Poindexter, ${ }^{120}$ suggesting that if Rogers still had any drawings from the 1893 Virginia Building, they could have been available to Poindexter's partner, Charles K. Bryant. Bryant was remarkably enterprising and dominated the business of Mount Vernon replication for the next two decades.

The 1915 replica was, like the 1893 version, described as an "exact replica of Mount Vernon."121 The house recreated the bedrooms of George and Martha Washington, the family dining room, parlor, and library, as well as the detached kitchen and servants hall to either side of the main mansion. ${ }^{122}$ The building was filled with Washington relics. Though Rogers may have passed on the concept or actual drawings from his 1893 Virginia Building, Bryant made a new set of drawings at Mount Vernon in 1915 (Figure 42). ${ }^{123}$ The exhibit was mean to introduce Westerners to Mount Vernon as "thousands" would "for the first time learn all about the Virginia mansion where the Father of His Country dwelt."124 Once again, Virginia was presenting herself as mother to the country with the architecture of her founding father. In the address by Virginia

\footnotetext{
119 "Troopers Parade and Banquet," Richmond Dispatch, 12 March 1893, p. 8. Bryant would also later serve in the exclusive brigade, though Rogers was no longer part of the organization.

${ }^{120}$ Dated and handwritten will of Edgerton Stewart Rogers, 24 February 1899, Richmond Circuit Court, Richmond, Virginia.

121 "Old Virginia on View," The Washington Post, 20 December 1914, p. 4.

${ }^{122}$ Macomber, The Jewel City, 174.

${ }^{123}$ Bryant did have competition for the commission. Washington, DC firm of Marsh and Peter wrote to the MVLA in April 1914 requesting permission to make drawings of Mount Vernon in case they were chosen by the commission. They wished to "duplicate the building in a representative way" and sought their drawings to be "absolutely correct in every particular." Marsh and Peter to Harriet C. Comegys, 11 April 1914, "Mount Vernon Replicas" File, MVLA Archives, Mount Vernon, Virginia.

124 "Will Show Heirlooms," Washington Post, 10 January 1915, p. 16.
} 
governor Henry Carter Stuart at the fair's Virginia Day, Virginia is credited with bearing the population of the state of California:

For the filial devotion of these, her children, Virginia returns the fullest measure of maternal love and pride, rejoicing that it has been her privilege to give of her flesh and blood to the upbuilding of your great

Commonwealth... We bring you from Virginia not only greeting and assurance of good will and affection... ${ }^{125}$

As at the 1893 replica, the national narrative proved essential; Virginia was indispensable to the country and used the national symbol of Mount Vernon to succinctly pronounce this as fact.

Also in keeping with the 1893 Virginia Building, the 1915 replica had a hostess that acted as the human representative of the Colonial American domesticity presented in the exhibit. Nannie Randolph Heath, a Virginia woman active in Washington society, greeted visitors to the Virginia Building dressed in Colonial garb modeled after Martha Washington's own clothes. ${ }^{126}$ Like Lucy Preston Beale, Heath was from "one of Virginia's oldest families," and was the "center of a perfect picture of Mount Vernon as it was 115 years ago," ${ }^{\prime 127}$ completing the replicate atmosphere of the domestic structure.

Yet Heath's involvement with certain Southern organizations also reveals the presence of the regional narrative in the 1915 Virginia Building. Heath was president of the Southern Relief Society and the Virginia chapter of the United Daughters of the Confederacy. In fact,

her activity with Congress in behalf of Confederate soldiers is well known, and it was largely through her instrumentality that an appropriation was

\footnotetext{
${ }^{125}$ Hon. Henry Carter Stuart, "Address of Hon. Henry Carter Stuart, Governor of Virginia, Delivered at the Panama-Pacific International Exposition, San Francisco, Virginia Day, July 8, 1915," (Richmond: The Legislative Reference Bureau, 1915), 4-6.

${ }^{126}$ Heath owned a set of Martha Washington's dresses, inherited from Charles Goldsborough. See "Will Show Heirlooms," p. 16.

${ }^{127}$ Will Show Heirlooms," p. 16.
} 
set aside to apply on certain work that was being done by the government for the soldiers of the Confederacy, their wives and widows. ${ }^{128}$

In the press, Heath was specifically cited as being a representative not only of the state, but also of the Southern Relief Society, Confederate Veterans, Sons of Veterans, and the Southern Society in addition to the UDC. ${ }^{129}$ Though the building was an exhibit of Colonial American domesticity, it still emphasized the regional and limited narrative. Between the 1893 and 1915 world's fairs, large organizations such as the UDC had formed and gained power in the South, making their formal recognition part of Virginia's identity on display in the 1915 replica.

In addition to the direct implications of the human representative of the domestic memory were the celebrations that centered on Virginia Day at the fair, which "attracted more attention than any other occasion since the opening of the exposition." ${ }^{\prime 130}$ After Governor Stuart gave his speech hailing Virginia as the mother of all states, a tree was planted from Richmond and the Light Infantry Blues performed a "full dress parade in their showy uniforms on the parade ground." ${ }^{\prime 131}$ Though their uniforms were no longer Confederate grey, the presence of an elite group with the history of trying to "recreate" the life of the rebel soldier would not have gone unnoticed by those gathered at the celebration.

The regional narrative of white, elite Southern domesticity in the replicas of Mount Vernon persisted from the 1893 through the 1915 Virginia Buildings. While the

\footnotetext{
128 "Old Virginia on View," Washington Post, 20 December 1914, p. 4.

129 "Will Show Heirlooms," p. 16.

130 "Virginia Day Proves Biggest Success of Any Occasion at 'Frisco Exposition," Richmond News Leader, 9 July 1915 , p. 1.

131 "Virginia Day Proves Biggest Success," p. 1.
} 
presence of the Lost Cause myth would have gone unconsidered by many visitors thanks to the strong national connotations of Washington and his home, the limited memory of the white, Southern elite persisted. Only in the 1907 Jamestown Ter-Centennial Exposition, a celebration held on Virginia soil, was the Southern narrative more prominent than the national. These connotations would become obsolete, however, as the Mount Vernon replicas of the 1920s and 1930s faced new uses and fewer associations with regional identities. 


\section{CHAPTER III: \\ Shift from Regional to National Identifications}

While the earliest replicas of Mount Vernon represented the state of Virginia and were staunch attempts to present the house as an emblem of the cult of white Southern domesticity, later replicas represented America's early history in a more inclusive way. The Mount Vernon replicas of the 1920s and 1930s - erected at the 1926 SesquiCentennial in Philadelphia, at the 1931 Paris International Colonial and Overseas Exposition, and finally at the 1932 Bicentennial celebration held in Prospect Park, Brooklyn - replicated the iconic home not as a monument to Southern memory, but as an emblem of American domestic values. This was due largely to the fact that as these replicas progressed, their purpose and appeal became increasingly commercial in nature. This trend culminated in Sears, Roebuck and Company's 1932 pre-fabricated home that imitated Mount Vernon's distinctive portico. This shift also signifies the declining necessity for commemoration of the Lost Cause myth, the lack of interest in Victorian ideas of memory, and the ways in which state governments began to take control of the history and maintenance of public monuments. ${ }^{1}$

\section{Domesticity for Social Good: Mount Vernon at the 1926 Sesqui-Centennial}

While the 1926 Sesqui-Centennial International Exposition in Philadelphia, Pennsylvania was meant to commemorate the one hundred and fiftieth anniversary of the signing of the Declaration of Independence, its official architecture reflected the

\footnotetext{
${ }^{1}$ Fitzhugh W. Brundage, "White Women and the Politics of Historical Memory in the New South, 18801920," in Jumpin' Jim Crow: Southern Politics from Civil War to Civil Right, eds. Jane Daily, Glenda Elizabeth Gilmore and Bryant Simon (Princeton: Princeton University Press, 2000), 130-32.
} 
burgeoning American modernism of the $1920 \mathrm{~s} .{ }^{2}$ Though the fair in general proved to be unpopular and unsuccessful, ${ }^{3}$ the grounds' replicas of Colonial architecture were enormously admired, recalling the sensation made by the New England Kitchen and other such Colonial Revival exhibits at the Philadelphia Centennial fifty years earlier. A range of women's organizations from the League of Women Voters to the DAR created "High Street," an imaginative gathering of twenty replicas of famous Revolutionary period buildings (Figures 43 and 44). ${ }^{4}$ The conglomeration served as the most talked about exhibit at the fair, following the same patterns of success as previous nostalgic replicas of Colonial buildings and again playing on the interest in the Colonial Revival.

On the "quiet, flower-bordered stretch of road" that led into High Street, ${ }^{5}$ sat a replica of Mount Vernon constructed by the Young Women's Christian Association (YWCA) of Philadelphia for "service to visitors at the Exposition and employees in the grounds (Figures 45 and 46)." Although the 1926 building was called an "exact replica" of the original, ${ }^{7}$ it was not, and, therefore, differed substantially from its predecessors. Formally, the building did not replicate the original Mount Vernon's auxiliary structures, as did the 1893 and 1915 replicas. In addition, it did not contain exhibits or completely

\footnotetext{
2 "The architects of the exposition have endeavored to express current trends in design with the result that the 'set-back' system has been employed for the structures on grounds" ("Sesquicentennial Fair Shows Out Progress," New York Times, 23 May 1926, p. 24).

3 "The Sesqui a Financial Failure," The Literary Digest 91 (23 October 1926): 14.

${ }^{4}$ Sarah D. Lowrie and Mabel Stewart Ludlum, The Sesqui-centennial High Street (Philadelphia, Lippincott, 1926); Elizabeth Frazer, "1776-1926 at the Sesqui-Centennial," The Saturday Evening Post 199 (11 September 1926): 50-52+; "Dorthy Budd, "The Little Street of '76," The Woman Citizen 11 (August 1926): 21+; E. L. Austin and Odell Hauser, The Sesqui-Centennial International Exposition (Philadelphia: Current Publications, Inc., 1929), 160-173.

5 "Sesquicentennial Fair Shows Out Progress," p. 24.

${ }^{6}$ Mrs. J. Willis Martin, "Other Activities of Women," in The Sesqui-Centennial International Exposition, eds. Austin and Hauser, 180.

${ }^{7}$ Sesqui-Centennial International Exposition, A Pictorial Record of the Sesqui-Centennial International Exposition: Philadelphia, Pennsylvania, June 1st-December 1st, Nineteen Hundred Twenty Six Commemorating the One Hundred and Fiftieth Anniversary of the Declaration of Independence (Philadelphia: Sesqui-Centennial International Exposition, 1926).
} 
reproduce the architectural details of Mount Vernon. Like the previous facsimiles, however, the building did have a domestic function: it was primarily a cafeteria capable of serving up to three hundred people on the trademark veranda and ground floor. The building also hosted a concierge that provided everything from emergency services to suggestions on where to stay while visiting Philadelphia, a Foreign Services Corner, an exhibit of Centennial souvenirs, a lounge, and an extra cafeteria services for fair employees. ${ }^{8}$ The building was no longer a monument to Colonial domesticity in the sense of the Virginia Building replicas; it was instead a shell meant to accommodate visitors in the most utilitarian ways, needing only the portico and general massing in order to convey the memory of the original. Mount Vernon's role as an icon of domesticity was essential to the YWCA's choice to use it as a model, however: if the purpose of the building was to be a center for hospitality, what better representation than the ultimate domestic form? The fact that the building's most important function - the cafeteria service - took place on Mount Vernon's most distinctive feature - the portico signifies this simplification of the building and its meaning. Yet the hospitality of the 1926 Building was not explicitly Southern, but more generally linked to the status of Mount Vernon as an icon of American domesticity.

Though the building did have a domestic purpose and, therefore, provided a link to its former Mount Vernon replica predecessors, the players in the 1926 replica - the YWCA - were completely uninterested in the Lost Cause myth and were perhaps the antithesis of the organizations represented by Lucy Preston Beale and Nannie Randolph Heath. The YWCA was founded in the mid-nineteenth century in response to urban

\footnotetext{
${ }^{8}$ Martin, "Other Activities of Women," 80.
} 
growth caused by massive spikes in immigration. ${ }^{9}$ There were no membership requirements other than agreement to pay the modest dues and to belong to a Protestant congregation, separating the organization from other women's societies that were based on their members' genealogy. By the time of the Sesqui-Centennial in the 1920 s, the YWCA was embracing ethnic pluralism in response to the growing heterogeneous urban population and had chapters, though separate, of African American women. ${ }^{10}$ The YWCA was not advocating regional or elitist memories of American domesticity in the 1926 replica, but merely emphasizing the hospitality and general services that were part of their mission to help the urban poor. While a nearby replica of Sulgrave, the ancestral home of George Washington in England, was erected by the Colonial Dames of America and, therefore, promoted a genealogically limited version of American history, ${ }^{11}$ the Mount Vernon replica at the Sesqui-Centennial offered an opportunity for the entire nation - and even foreign visitors - to participate in the memory of Mount Vernon. Gone was the regional narrative and subdued was the elitist version of Colonial American history emphasized at the 1893, 1907, and 1915 world's fairs.

\section{Mount Vernon as International Ambassador}

In 1931, Mount Vernon was appropriated again for a world's fair by an entity greater than the Virginian elite. The United States government created a replica of Mount Vernon to serve as its main exhibition building at the Paris International Colonial and Overseas Exposition (Figures 47 and 48), marking it as the "first officially sanctioned

\footnotetext{
${ }^{9}$ See Nina Mjagkij and Margaret Spratt, introduction to Men and Women Adrift: The YMCA and YWCA in the City (New York: New York University Press, 1997), 6.

${ }^{10}$ Mjagkij and Spratt, introduction to Men and Women Adrift, 10.

${ }^{11}$ The Sulgrave replica was created from measured drawings of the original. See Elizabeth Frazer, "1776$1926, " 52$.
} 
US exhibit at any European colonial exposition." ${ }^{\text {"12 }}$ The project was discussed in the same terms as those of the earlier Virginia Building replicas, both by the press and by government officials, yet there is virtually no mention of the building as being particularly Southern or Virginian. The symbol of Mount Vernon was thus appropriated as a symbol of idealized American domestic values.

The choice of Mount Vernon to represent American domestic values was dependent upon its authenticity, relying on the same strategies as the 1893 and 1915 replicas. The measured drawings of Mount Vernon by Charles K. Bryant made for the Virginia Building at the 1915 Panama Pacific Exposition in San Francisco were put to use once again and the venture was sanctioned by the Mount Vernon Ladies' Association. ${ }^{13}$ To further the building's physical credibility, the site again imitated Mount Vernon's slope towards the Potomac as it looked to the river Seine in the distance. ${ }^{14}$

The historic meeting between France and America on the porch of Mount Vernon, enacted through the personal relationship between Washington and Lafayette, also contributed to the authenticity of the domestic structure in a foreign location (Figure 49). In a speech given at the U.S. Building on the anniversary of Washington's birth, French minister of Colonies Paul Reynaud stated: "it was from this aristocratic mansion of American Colonial style that Washington departed to fight for liberty-something which

\footnotetext{
${ }^{12}$ Robert W Rydell, World of Fairs: The Century-Of-Progress Expositions (Chicago: University of Chicago Press, 1993), 72.

${ }^{13}$ See correspondence between the commission and the MVLA in Paris 1931 File, Mount Vernon Ladies Association Archives, Mount Vernon, Virginia.

14 "Mount Vernon in France," Washington Post, 18 February 1931, p. 6; "Sail to Reproduce Mount Vernon in Paris," New York Times, 26 October 1930, p. NI.
} 
was so sacred to Frenchmen." ${ }^{\text {15 }}$ Mount Vernon had evolved from a symbol to be appropriated only by the elitist American South, to one embraced by the nation and the larger western European conglomerate to represent relationships between nations. The choice also had particular contemporary symbolic importance as France and the U.S. had been allies during World War I and would soon be again during World War II. In fact, while George and Martha Washington's bedrooms had been key destinations in the Virginia Building of 1893, the room in which Lafayette had slept during his visit to Mount Vernon was heavily publicized as an essential part of the 1931 replica (Figure 50). The 1931 fair descriptions also highlighted a reproduction of a rug given to George Washington as a gift by Louis XVI, a key to the Bastille, and a chair presented to Martha Washington by Lafayette himself exhibited in the building, ${ }^{16}$ while Washington's and other Virginian founding fathers' personal effects were instead emphasized in press regarding the 1893 and 1915 replicas. In the post World War I era, specifically Southern hospitality was not emphasized, but instead the general "quiet dignity, simple charm and the friendly hospitality of [America's] founders." ${ }^{\prime 17}$ Once again, the values stressed in the national narrative as expressed through the Colonial Revival - ease and repose - were echoed.

The building's hostess, Anne Madison Washington, also ensured the authenticity of the domestic structure (Figure 51). Not only was she an actual descendant of George and Martha Washington, ${ }^{18}$ but she was also the building's only inhabitant, sleeping

\footnotetext{
${ }^{15}$ Paul Reynaud quoted in "Edge, in Paris Talk, Praises Lafayette," New York Times, 23 February 1931, p. 12.

16 "Sail to Reproduce Mt. Vernon in Paris."

${ }^{17}$ C. Bascom Slemp quoted in Carlisle MacDonald, "Mount Vernon Reproduction Opened in Paris; Edge's Praise of Exposition is Heard Here," New York Times, 27 May 1931, p. 1.

${ }^{18}$ She was the great-great grand-niece of George and Martha Washington.
} 
upstairs in the exposition structure. Though the Mount Vernon was an exhibit hall, it was most importantly a home, inhabited by one of its own descendants. In fact, the "sacred" nature of the domestic symbol prevented its use for any purpose other than as a domestic recreation. ${ }^{19}$ Anne Madison Washington did aid an air of regional association to her role, though she did not betray the building and its intention as a national symbol. A Good Housekeeping correspondent would attest:

Miss Washington's accent is as Southern as her background, but her outlook has no regional restrictions; hospitality comes as naturally to her as breathing; so does graciousness in its dispensation. She is typical of everything that Virginia has produced in its finest flower, and you know that this is equivalent to saying that she is typical of the finest femininity in the world. ${ }^{20}$

Even as she evoked romanticized notions of Southern culture, Washington was not

evaluated in terms of her regional affiliation as were previous hostesses Nannie Randolph Heath or Lucy Preston Beale. She, like the house into which she welcomed visitors, was instead a symbol of Colonial American domesticity on an international scale.

The 1931 replica was not completely without the racial and social implications of its eighteenth-century Southern memory, however. The fact that the building was the home of a plantation owner who took advantage of slave labor was significant considering that the idea of the fair was to showcase France and other major international powers' colonial holdings. ${ }^{21}$ While the main building was strictly historical in the nature of its exhibits, five subsidiary structures - built, according to Bryant's drawings, in the place of the utilitarian buildings to either side of the mansion on the original estate - held

\footnotetext{
19 "We are sacredly avoiding any misuse of the building and will not even use it for administrative purposes" (Letter from Charles H. Burke, Commissioner, to Frances J. Rogers of the MVLA, 14 February 1931, Paris 1931 File).

${ }^{20}$ Frances Parkinson Keyes, "Tricolor and Stars and Stripes Float Together Over The Greatest Show on Earth," Good Housekeeping 93, no. 5 (November 1931): 199.

${ }^{21}$ Rydell, World of Fairs, 75.
} 
exhibits of America's territories in Guam, the Phillipines, Samoa, Puerto Rico, the Virgin Islands, and Alaska (see Figures 4 and 42). The relationship of buildings within the complex suggested that the smaller structures resembled slave quarters, ${ }^{22}$ though these associations went unmentioned and unnoticed by the contemporary press. This reading of the social and racial hierarchy present in the 1931 replica does provide continuity, however, with the memory evoked in the 1893 and 1915 Mount Vernon replicas; though the narrative suggested in 1931 was no longer regional, it remained socially and racially limited.

The building, much like the Mount Vernon cafeteria of 1926, also differed substantially from the rest of the exposition's structures, emphasizing its domestic nature. Mount Vernon was frequently cited as a source of repose among the "bizarre" exhibits of foreign places. One correspondent wrote of the contrast for The Washington Post: "From a nearby temple comes the sound of Hindu music played by an indefatigable snake charmer, and across the street one hears the chanting of the Balian priest, but in the midst of this, like a shrine, stands the quiet home of George Washington."23 Another reporter recalled a similar interpretation: "situated in the midst of strange African and Far Eastern temples and gardens, the simple, almost severe, lines of this early American Colonial architecture are in sharp but none the less charming contrast to their surroundings." 24 The contrast between the Mount Vernon and the exotic foreign exhibits signified American values as honest, clear, and simple - those same values that were central to the Colonial Revival. In fact, these qualities as represented in American architecture were

\footnotetext{
${ }^{22}$ Rydell, World of Fairs, 75.

${ }^{23}$ Eveyln Gordon, "Replica of Mount Vernon One of Outstanding Buildings at Exposition in Vincennes," The Washington Post, 23 August 1931, p. 83.

${ }^{24}$ Carlisle MacDonald, "France Opens Fair of All Its Colonies," New York Times, 7 May 1931, p. 10.
} 
said to have surprised some modern Parisians who "had no idea that anything so perfect had been achieved in America in the eighteenth century."25 Since the 1876 Centennial, Americans had been trying to counteract the belief held by Europeans that they were entirely corrupted by materialism; ${ }^{26}$ the replica of Mount Vernon in 1931 was, therefore, a clear symbol of the "straight-forward spirit and true value"27 of early American domesticity.

However, the Mount Vernon at the 1931 World's Fair was hardly a commercialfree venture. In fact, it marked the transition of the world's fair Mount Vernon replica from a regional identity statement to an advertising platform for American manufacturers of domestic goods. While the discussions of previous replicas had been in terms of their historic qualities, the descriptions of the 1931 replica were inundated with commercial notations. Sears, Roebuck and Company constructed the building, connecting the venture publicly with the major American mail-order business that was at the peak of its involvement in the domestic housing market in the late 1920s. The Mount Vernon replica as designed by Charles K. Bryant was prefabricated by Sears, shipped from the company's private wharves in Newark, New Jersey within weeks, and then constructed with foreign labor at the exposition site in Paris. ${ }^{29}$ The rapidity of construction and the entirely manufactured nature of the building evoked the superiority of American building techniques, regardless of the simple and pastoral values it was also meant to induce.

\footnotetext{
25 "Best in Mount Vernon Replica," n.d., Paris 1931 File. Bryant would be honored by an award presented by the French government for recognition of his fine work on the Mount Vernon replica. "France Honors Virginian," Richmond News Leader, 28 April 1933, p. 14.

${ }^{26}$ Dutton, "Art-Culture," Chicago Daily Tribune, 14 May 1876, p. 5.

${ }^{27}$ C. Bascom Slemp quoted in MacDonald, "Mount Vernon Reproduction Opened in Paris," p. 10.

29 "Sail to Reproduce Mt. Vernon in Paris."
} 
In addition to the actual building's embodiment of the image of American manufacturing, the furnishings was also "a tribute to the entire American furniture industry." ${ }^{30}$ Reproductions of colonial period furnishings by Grand Rapids furniture companies outfitted the building and potential consumers were often reminded that the very same furniture could be bought through many major American retailers. ${ }^{31}$ In Good Housekeeping's feature on the fair building, the reproduction furniture takes center stage (Figure 52). The building and its furnishings were, therefore, participating in the larger American Colonial Revival movement in that they were commodifiying the "simplicity" and "honesty" of a period that Americans were striving to recreate. Because these products were available to the wider public (and often more readily available in the large, Midwestern cities in which they were manufactured), they symbolized the way in which Mount Vernon replicas had deviated from a symbol identified with by elitist Southerners. Everybody wanted a piece of Mount Vernon's past; the replica at the 1931 Paris exposition was later purchased and rebuilt in Vannessor, France, where its inhabitants furnished it with colonial reproduction furniture. ${ }^{32}$

\section{Mount Vernon Grows in Brooklyn}

The following year, the nation geared up for a host of activities celebrating the bicentennial of George Washington's birth. ${ }^{33}$ Although there was a federal commission

\footnotetext{
30 "Best in Mount Vernon Replica."

31 "Best in Mount Vernon Replica;" "Replica of Mount Vernon At the International Colonial Exposition In Paris." Good Housekeeping 92, no. 5 (May 1931): 68-9+.

${ }^{32}$ The building was purchased by an American, Dr. Alexander Bruno of New York, who then gave it to his daughter Gloria Bruno. She married Frenchman Comte de Pierrefeu and inhabited the structure through World War II.

${ }^{33}$ For an account of Bicentennial celebrations across the United States, see Karal Ann Marling, George Washington Slept Here: Colonial Revivals and American Culture, 1876-1986 (Cambridge: Harvard University Press, 1988), 325-64.
} 
established to oversee events throughout the country, a national event was not considered. Instead, regional celebrations were encouraged. ${ }^{34}$ New York City's celebration was one of the largest of these commemorations and its central feature was a replica of Mount Vernon (Figures 53 and 54), a venture that borrowed many figures and actual materials from the Paris replica of the previous year. ${ }^{35}$ Again, Mount Vernon was enlisted as a carrier of the memory of colonial American domesticity and was not particularly Southern.

The Mount Vernon replica at the New York Bicentennial, erected in Brooklyn's Prospect Park, was again a symbol of Washington's domestic life. It was foiled by a replica of Federal Hall, the building in which Washington was first inaugurated, which was erected in Manhattan's Bryant Park (Figure 55). ${ }^{36}$ Together the two replicas completed the metaphor of Washington as Cincinnatus: as both statesman and head of household. The official handbook of the Prospect Park replica makes this distinction clear:

In this replica of Mount Vernon, an attempt has been made to recreate the atmosphere of the mansion where Washington lived with his family, entertained his friends and pursued the existence of a country gentleman, as well as to increase our knowledge of him as an individual...In the replica of Federal Hall... are illustrated the public aspect of Washington's life. $^{37}$

\footnotetext{
${ }^{34}$ After all, it was this group and this event that occasioned complementary distribution of 750,000 color reproductions of Gilbert Stuart's portrait of Washington for "every" public school classroom in the United States, with special emphasis on rural areas. See Marling, George Washington Slept Here, 333 and Sol Bloom, The Autobiography of Sol Bloom (New York: G. P. Putnam's Sons, 1948), 216.

35 "Park Site Suitable to New Mt. Vernon," New York Times, 6 March 1932, p. N3.

${ }^{36}$ Federal Hall was also reproduced at the 1926 Sesqui-Centennial as one of two buildings to represent the state of New York. It was foiled there by a domestic structure - the Newburgh farmhouse that Washington used as headquarters during the Revolutionary War.

${ }^{37}$ Official Handbook of the Replica of Mount Vernon, Mount Vernon, Replicas of File, MVLA Archives, Mount Vernon, Virginia.
} 
While the Mount Vernon replica was held as sacred, containing only relics and reproductions of furniture and spaces from its model, the Federal Hall included space for civic and patriotic gatherings in addition to exhibits of Washington relics. ${ }^{38}$ Similar to the distribution of exhibits at the 1931 Paris Exposition, the Mount Vernon replica was reserved as a sanctuary of Colonial American domesticity, supposedly unmarred by modern life. ${ }^{39}$

Although the Federal Hall replica had local significance in that it was once located on Manhattan's Wall Street, Mount Vernon had little to do with New York specifically. Regardless of the rift between the regional nature of the celebration and the location of the actual Mount Vernon, the building was elected as the most appropriate means to symbolize Washington's domestic life. During the early debates about the nature and location of the celebrations in New York City, some members of the Kings County Historical Society argued that replicating Mount Vernon in Brooklyn was inappropriate because the building had nothing to do with Washington's actions in New York specifically. ${ }^{40}$ They suggested instead using the money raised for the replica to restore the Old Stone House of Gowanus at Fifth Avenue and Third Street, Brooklyn, as it was where Washington supposedly stood during the Battle of Long Island. The Mount Vernon replica prevailed, however, most likely because of the permeability of the national narrative of the building in the American memory. In addition, the very people who had built the lucrative 1931 replica promoted the concept with great success. They marketed the Brooklyn project to local and state politicians as a surefire means of

\footnotetext{
${ }^{38}$ For a description of the exhibits in both buildings see The Official Handbook and "Prospect Park Gets Washington Shrine," New York Times, 20 February 1932, p. 1.

${ }^{39}$ The building was wired for electricity, however.

${ }^{40}$ See "Shrine Chosen in Prospect Park," New York Times, 24 February 1932, p. 5.
} 
increasing tourism for the city during the fiscally difficult moment of the Great Depression. The hope was that the Mount Vernon in Prospect Park would be "the Mecca for the Eastern seaboard during the year 1932..41 As far as actually connecting the building with the local memory of George Washington, it was enough that the replica was placed near the location where Washington was said to have stood during the Battle of Long Island. Mount Vernon no longer evoked the regional narratives present in previous replicas; it was simply a symbol of Washington himself. At the inauguration of the replica, this point was made clear: "In bringing Mount Vernon to New York we bring George Washington here. To a degree true of no other structure in connection with any historical character, Mount Vernon is a symbol of the man."

The language of the contemporary press and the officials of the commission further insisted that the building was no longer primarily associated with its Southern heritage. Much like the discussions over the 1931 replica, Mount Vernon's general rural character was emphasized, not its actual geographical location. Just like previous replicas, the 1932 replica attempted to approximate the grade changes of the site. ${ }^{43}$ There was a large debate over whether to place the replica in the dilapidated Bryant Park or elsewhere in New York before the Brooklyn site was chosen. Those who argued that "Mount Vernon is a country estate...[it] demands a rural or country setting" 44 prevailed and the replica was constructed at the foot of Prospect Park's Lookout Mountain, facing the peninsula on the north end of the lake. Throughout the descriptions approximating the

\footnotetext{
41 "Rebukes Opposition to Shrine in Park," New York Times, 23 February 1932, p. 28.

${ }^{42}$ Grover A. Whalen, Chairman of the New York City Commission of the Bicentennial Commission, quoted in "Mount Vernon Site Dedicated in Park," New York Times, 29 February 1932, p. 14.

${ }^{43}$ "Park Site Suitable to New Mt. Vernon," p. N3.

44 "Prospect Park Gets Washington Shrine," p. 1.
} 
pastoral qualities of the Brooklyn site to those of Mount Vernon on the Potomac, there was virtually no mention of the building as particularly Southern.

Also like the 1931 Paris Exposition Building, the domestic qualities of Mount Vernon in Prospect Park were emphasized by its connections to the marketable Colonial Revival. Even in the midst of the Great Depression, the consumer was targeted with the 1932 replica, perhaps even more successfully because the qualities recalled by the Colonial Revival - simplicity and plainness - were those that were being forced on the fiscally limited American public. The building was again designed by Charles K. Bryant and fabricated and constructed by Sears, Roebuck, and Company, using the exact plans and production format as the 1931 replica. In addition, Sears owned the building itself, ${ }^{45}$ making the venture a great marketing ploy for a company selling pre-fabricated, Colonial Revival houses. Also similar to the Paris Mount Vernon were the furnishings and interiors of the house, all Colonial Revival pieces manufactured by American companies and available for sale in American department stores and mail order catalogues. The Official Handbook for the Mount Vernon Replica listed the pieces by room, each annotated with the name of the Grand Rapids manufacturer who provided them, therefore making it easier for the visitor to track the products for the furnishing of their own home (Figure 56). Even the landscape was for sale; a Westchester nursery donated the materials for the formal colonial gardens that accompanied the reproduction. The chairwoman of the Women's Committee of the Greater New York Bicentennial Commission stated: "So many women have told me that the Mount Vernon replica was a revelation to them as to what a home of George Washington's time could be like... They

\footnotetext{
${ }^{45}$ Sears also paid for the Federal Hall replica and was to continue to own both under contract until the Commission could repay the company with profits collected from entrance fees. The Commission ran into considerable financial problems.
} 
look upon it as an example of good taste and have told me it should be left standing because of its great educational value to the public."46 The 1932 Mount Vernon replica was, therefore, a model domestic environment.

\section{The Memory on the Market}

The domestic qualities evoked in the 1930 s replicas were the very aspects of Mount Vernon that the American public embraced and could potentially purchase. By seeing how Washington lived as created and displayed by American manufacturers, the average American could then hope to approximate this in their own home. The commercial uses of these structures, therefore, symbolized the lack of regionalism associated with the symbol of Mount Vernon; the memory was no longer Southern if it could be bought by any American who could afford it. No company better took advantage of the commercial potential of the replicas as Sears, Roebuck, and Company. In 1932, Sears began selling "The Jefferson," a two-story abode with the distinctive double-height Mount Vernon portico (Figure 57). The house would again appear in the catalogues of 1933 and 1937. The design was supposedly "designed along the same lines as historic Mt Vernon," ${ }^{, 47}$ though it did not go far beyond white painted brick, dark green roof and shutters, and the distinctive portico. Other than a possible nod to Mount Vernon's large central hall and dining room (the large room to the left of the entrance), the floor plan did little to imitate its model, but instead boasted a sunroom, indoor bathrooms, and a multitude of closets (see Figures 3 and 57). Mount Vernon was

\footnotetext{
${ }^{46}$ Mrs. William H. Good quoted in "Straus Fights Plans to Keep Mt. Vernon," New York Times, 15 June 1933 , p. 21.

${ }^{47}$ Sears, Roebuck and Company Home Catalogue (1933?), 30.
} 
reduced to a domestic housing type that could be manipulated to serve contemporary needs.

Described as a "Southern colonial home," 48 both the original model and its regional connotations were similarly evoked only as a means to brand the product. These suggestions as well as the mention that "the Southern colonial has held its share of popularity and today is classed as one of the truest types" ${ }^{\prime 49}$ ensured the style as something that had withstood the test of time, a means to assure a potential customer at the height of the Great Depression. The style's Southern heritage as implicated suggests a romanticized understanding of the American South: something conservative and long lasting in its traditions. The fact that the company had stopped offering home financing in 1932, the same year as "The Jefferson," also suggests that they were using the Colonial Revival, a movement reminiscent of "better, simpler" days, as a means to reassure their customers of the company's own fiscal stability. In stating that the design "spells success, ${ }^{, 50}$ the advertisement claims that the owner of "The Jefferson" has the potential to be as prosperous as the founding fathers it evokes. This promoted hope for the potential buyer in a difficult era.

The history of Sears and Roebuck as a company that extended credit to its customers and offered mortgages earlier and more generously than federal $\operatorname{organizations}^{51}$ also suggested the egalitarian potential of the Mount Vernon phenomena. The title of the product, "The Jefferson," also would have had classless connotations. Because the title "Mount Vernon" and a variation on a theme, the "Martha Washington,"

\footnotetext{
${ }^{48}$ Sears, Roebuck and Company Home Catalogue (1933?), 30.

${ }^{49}$ Sears, Roebuck and Company Home Catalogue (1933?), 30.

${ }^{50}$ Sears, Roebuck and Company Home Catalogue (1933?), 30.

${ }^{51}$ Michael W. R. Davis and Robert Schweitzer, America's Favorite Homes (Detroit: Wayne State University Press, 1990), 66.
} 
had already been used for home models of the 1920s (Figures 58 and 59), another name was sought. Most likely, Thomas Jefferson's surname was used because he was an alternative, Southern founding father to Washington and one that was growing in popularity at the moment the product was introduced. ${ }^{52}$ After Claude G. Bowers's book Jefferson and Hamilton: The Struggle for Democracy in America was released in 1925, the American public reevaluated Jefferson's image; the memories of his great statesmanship and egalitarian approach to government were revived. ${ }^{53}$ President Franklin Delano Roosevelt relied heavily upon Bowers's Jefferson in his campaign for the American Democratic party and would cite the New Deal as a means to realize Jeffersonian individualism on a modern scale. ${ }^{54}$ By linking the revamped Jefferson to a product meant to evoke feelings of comfort and straightforward honesty, Sears and Roebuck were reinforcing the very egalitarian implications of Mount Vernon's image denied by the early replicas and encouraged in the increasingly commercial facsimiles of the 1930 s.

The replicas of Mount Vernon erected at substantial public events in the 1920s and 1930s no longer depended upon the exclusively elitist Southern memory of the 1893 and 1915 replicas. Instead, they promoted ideas of Mount Vernon as a national symbol of Colonial American domestic values without need for specific regional connotations. This was achieved in 1926 through its appropriation by a progressive female organization and in the 1931 and 1932 replicas through a gradually increasing commercial aspect that

\footnotetext{
${ }^{52}$ Records do not exist as to why the title "The Jefferson" was chosen for Sears and Roebuck's Mount Vernon. Rebecca Hunter, Sears, Roebuck and Company Archives, electronic correspondence to author, 25 April 2006.

${ }^{53}$ See Merrill D. Peterson, The Jefferson Image in the American Mind (New York: Oxford University Press, 1960), 330-376.

${ }^{54}$ Peterson, The Jefferson Image in the American Mind, 356.
} 
geared Mount Vernon to be a product for the average American. With World War I, the Great Depression, and the increasing modernization of everyday life, the American consumer retreated to their homes as a place of refuge and shelter. The national narrative of the Colonial Revival was promoted as a way to return the American home to its classic domestic values of simplicity and conservative style and Mount Vernon was once again its iconic image.

Mount Vernon is a vivid symbol in American memory. Though its replicas focused on or appropriated its memory for different purposes, they stayed true to the architectural character and detail of its original. Through these replicas, Mount Vernon was erected time and time again despite a variety of shifting movements in both academic and popular architecture - everything from the American Renaissance to the Moderne - a testament to the steadfast popularity of perceived eighteenth-century simplicity in the American architectural canon. The late nineteenth and early twentieth-century groups that selected Mount Vernon to serve their carefully crafted identities while later replicas depended upon more far-reaching national associations to ensure the popularity and marketability of a product. Throughout, however, Mount Vernon persisted in its role as a physical manifestation of George Washington's domestic values. Whether it was Southern hospitality or Depression era frugality, the simplicity and repose embodied in the simple white portico and asymmetrical façade was emulated and longed for by the American public. 


\section{BIBLIOGRAPHY}

\section{Archival Sources}

Bryant, Charles K. Measured Architectural Drawings of Mount Vernon. Mount Vernon Ladies' Association Archives, Mount Vernon, Virginia.

Charles E. Smith Papers, 1881-1900. Section 1. Virginia Historical Society, Richmond, Virginia.

"Death of Lucy S. Preston." 1891. Broadside, University of Virginia Special Collections, Charlottesville, Virginia.

"Fiftieth Anniversary, January 29, 1927, Westmoreland Club, Richmond, Virginia." The Library of Virginia, Richmond, Virginia.

Files on Mount Vernon Replicas. Mount Vernon Ladies Association, Mount Vernon, Virginia.

Maymont Archives, Richmond, Virginia.

Anna Cora Ritchie Papers, Special Collections, The University of Virginia Library.

Sheffey-Peters, M. Mrs. Lucy Preston Beale: A Lady of Charming Manners and Diplomatic Address. Broadside, from The Daily Progress (14 January 1893), University of Virginia Special Collections, Charlottesville, Virginia.

World's Fair Board of Managers of Virginia. Visitor's Register, Mount Vernon Building, World's Fair, May 25 - December 9, 1893. Library of Virginia, Richmond, Virginia.

\section{Primary Sources}

Apperson, John Samuel. Communication from the Governor Inclosing the Report of the World's Fair Commissioners. Senate Doc. 16, 7 November 1893. Richmond: 1893.

Association for the Preservation of Virginia Antiques, Yearbook of the Association for the Preservation of Virginia Antiques, 1896.

Austin, E. L. and Odell Hauser. The Sesqui-Centennial International Exposition. Philadelphia: Current Publications, Inc., 1929.

Bancroft, Hubert Howe. The Book of the Fair. Chicago: The Bancroft Company, 1893. 
Beale, Lucy Preston. An Address to the Women of Virginia. Virginia: Buchanan Standard Steam Print, 1890-93(?).

Bloom, Sol. The Autobiography of Sol Bloom. New York: G. P. Putnam's Sons, 1948.

Budd, Dorothy. "The Little Street of '76." Woman Citizen 11 (August 1926): 21+.

“Capt. Edgerton S. Rogers.” Inland Architect and News Record 38, no. 4, 32.

Cardinell, John D. A Pictorial Record of the Sesqui-Centennial International Exposition, Philadelphia, Pennsylvania, June $1^{\text {st }}$-December $1^{\text {st }}$ Nineteen Hundred Twenty Six, Commemorating the One Hundred and Fiftieth Anniversary of the Declaration of Independence of the United States. Philadelphia?: John D. Cardinell, 1926 ?.

Cunningham, Ann Pamela. In Mount Vernon Record 1, no. 1 (July 1858): 1.

The Dream City: A Portfolio of Photographic Views of the World's Columbian Exposition (St. Louis: N. D. Thompson Publishing Co., 1893.

Dutton, "Art-Culture," Chicago Daily Tribune, 14 May 1876, p. 5.

Eggleston, R. Beverly. Four Days at Chicago: Descriptive and Historical. Richmond: Whittet and Shepperson, 1901.

Everett, Edward. The Mount Vernon Papers. New York: D. Appleton and Company, 1860.

Flinn, John Joseph. Official Guide to the World's Columbian Exposition in the City of Chicago...May 1 to October 26, 1893 ...". Chicago: The Columbian Guide Company, 1893.

Ford, Paul Leicester. The True George Washington. Philadelphia: J. B. Lippincott Company, 1896.

Frazer, Elizabeth. "1776-1926 at the Sesqui-Centennial." The Saturday Evening Post 199 (11 September 1926): 50-1+.

----- "Our Sesquicentennial: Celebrating the Nation's One Hundred and Fiftieth Birthday." The Saturday Evening Post 198 (24 April 1926): 16-17+.

G., J. A. "Mount Vernon and the Mount Vernon Association." The American Monthly Magazine (The Official Magazine of the Daughters of the American Revolution) 2, no. 5 (May 1893): 530-533.

"Historic Mount Vernon Goes to Paris." The Houston Chronicle (22 February 1931). 
"In and About the Fair," Scribner's Monthly 12, no. 5 (September 1876): 742.

Ingram, J. S. The Centennial Exposition, Described and Illustrated Being a Concise and Graphic Description of this Grand Enterprise Commemorative of the First Centenary of American Independence ... Philadelphia: Hubbard Bros., 1876.

Johnson, Rossiter, ed. A History of the World's Columbian Exposition. New York: D. Appleton and Company, 1897.

Keiley, Charles R., ed. The Official Blue Book of the Jamestown Ter-centennial Exposition, A. D. 1907. Norfolk: The Colonial Publishing Company, 1909.

Keyes, Frances Parkinson. "Tricolor and Stars and Stripes Float Together Over The Greatest Show on Earth." Good Housekeeping 93, no. 5 (November 1931): 28$9+$.

Lowrie, Sarah D. and Mabel Stewart Ludlum. The Sesqui-centennial High Street. Philadelphia, Lippincott, 1926.

“Lucy Preston Beale, ex -'64,” The Hollins Alumnae Quarterly 3, no. 2 (July 1928): 19.

Macomber, Ben. The Jewel City: Its Planning and Achievement; Its Architecture, Sculpture, Symbolism, and Music; Its Gardens, Palaces and Exhibits. San Francisco: John H. Williams, 1915.

Molitor, John. "How the Sesqui-Centennial Was Designed." The American Architect 130 (5 November 1926): 377-84, pl. 265-74.

Morrison, Andrew. Richmond, Virginia, and the New South. Richmond: George W. Engelhardt \& Co., 1889.)

-----, ed. The City on the James: Richmond, Virginia, The Chamber of Commerce Book. Richmond: George W. Engelhardt, 1893.

Mount Vernon Ladies Association. 1891 Minutes of the Council of the Mount Vernon Ladies Association of the Union, May 1891. New Haven: Tuttle, Morehouse, and Taylor, Printers, 1891.

-----. 1892 Minutes of the Council of the Mount Vernon Ladies Association of the Union, June 1892. New Haven: Tuttle, Morehouse, and Taylor, Printers, 1892.

----- 1893 Minutes of the Council of the Mount Vernon Ladies Association of the Union, May 1893. New Haven: Tuttle, Morehouse, and Taylor, Printers, 1893. 
-----. Historical Sketch of Ann Pamela Cunningham: "The Southern Matron," Founder of "The Mount Vernon Ladies' Association." New York: Marion Press, 1903.

Mount Vernon Record 1, no. 11 (May 1859): 140.

Newton, Mary Mann Page. Colonial Virginia: A Paper Read Before the Historical Congress at Chicago. Richmond: West, Johnston \& Co., Publishers, 1893.

New York Times, 13 June 1891 - 14 June 1933.

"Our National Birthday Celebration." The Saturday Evening Post 199 (28 August 1926): 24.

Page, Thomas Nelson. Mount Vernon and Its Preservation: 1858-1910. New York: Knickerbocker Press, 1910.

"Replica of Mount Vernon At the International Colonial Exposition In Paris." Good Housekeeping 92, no. 5 (May 1931): 68-9+.

"Report by the Regent of Virginia" The American Monthly Magazine (The Official Magazine of the Daughters of the American Revolution) 2, no. 5 (May 1893).

"Restoration of Mt. Vernon," The Sunday Sentinel (Milwaukee), 8 August 1897.

Richmond Dispatch, 2 February 1893 - 20 August 1901.

Richmond Elite Directory (Blue Book). Richmond: J. H. Hill Printing Co., 1893.

Richmond News Leader, 9 July 1915 - 23 December 1933.

Rogers, Edgerton Stewart. "Details: Sketches by Edgerton S. Rogers, archt." Inland Architect and News Record 21 (April 1893): pl. fol. p. 42.

-----. Last Will and Testament, 24 February 1899. Circuit Court of the City of Richmond, Virginia.

"The Sculptor of the Doors of the Capitol." Harper's Weekly 35, no. 1832 (30 January 1892): 116.

"The Sesqui a Financial Failure." The Literary Digest 91 (23 October 1926): 14.

Schuyler, Montgomery. "State Buildings at the World's Fair." Architectural Record 111 (July-September 1893): 55-71. 
Stuart, Hon. Henry Carter. "Address of Hon. Henry Carter Stuart, Governor of Virginia, Delivered at the Panama-Pacific International Exposition, San Francisco, Virginia Day, July 8, 1915." Richmond: The Legislative Reference Bureau, 1915.

Swanson, Claude A. Address of Governor Swanson on 'Virginia Day' at the Jamestown Exposition, 1907. Richmond: D. Bottom, 1908.

Times (Richmond), 14 May 1891 - 20 August 1901.

Truman, Benjamin Cummings. History of the World's Fair: Being a Complete Description of the World's Columbian Exposition from Its Inception. Chicago: Monarch Book Co, 1893.

Tunis, A. B., ed. Press Reference Book of Prominent Virginians. Richmond: Virginia Newspaper Writers Association, 1916.

Tyler, Lyon G., LL.D., ed. Men of Mark in Virginia: Ideals of American Life. Volume 5. Washington, D.C.: Men of Mark Publishing Company, 1909.

Virginia Daughters of the American Revolution. History of the Virginia state society, Daughters of the American Revolution, N.S.D.A.R., with histories of the chapters from 1892-1928 inclusive; compiled by Jennie Thornley Grayson (Mrs. John Cooke Grayson) Virginia state historian D.A.R... Charlottesville, Va., The Michie Company, 1930.

The Virginian, Woman's Edition (28 November 1895).

Washington Post, 21 July 1890 - 15 February 1932.

Weems, Mason Lock. The Life of Washington. 1799. Reprint, with primary documents and an introduction by Peter S. Onuf, Armonk: M. E. Sharpe, 1996.

Westmoreland Club. The Constitution, By-Laws and House Rules of the Westmoreland Club of Richmond, VA. Richmond: The Bell Book and Stationery Co., 1909.

Wise, Jennings Cropper. Col. John Wise of England and Virginia (1617-1695): His Ancestors and Descendants. Richmond: The Bell Book and Stationery Co., Inc., 1918.

Wise, John S. The End of an Era. Boston: Houghton, Mifflin and Company, 1902.

World's Fair Board of Managers of Virginia. Organization, by-laws, plan of work, local and general of the Board of World's Fair Managers of Virginia including an Official Directory of the board of Managers, Officers of the Board and Auxiliary Board, and of the Officers of the Columbian Exposition at Chicago. Richmond: 1892. 
---. Proceedings of Meeting held at Roanoke, Virginia May 10, 11, and 12, 1892. Richmond: 1892.

\section{Secondary Sources}

Abbott, Carl. "Norfolk in the New Century: The Jamestown Exposition and Urban Boosterism." The Virginia Magazine of History and Biography 85, no. 1 (January 1977): 86-96.

Andrews, William D. "Women and the Fairs of 1876 and 1893." Hayes Historical Journal 1, no. 3 (1977): 172-83.

Axelrod, Alan, ed. The Colonial Revival in America. New York: Norton, 1985.

Ayers, Edward L. and John C. Willis, eds. The Edge of the South: Life in NineteenthCentury Virginia. Charlottesville: University Press of Virginia, 1991.

Badger, Reid. The Great American Fair: The World's Columbian Exposition \& American Culture. Chicago: Nelson Hall, 1979.

Bishir, Catherine W. "Landmarks of Power: Building a Southern Past, 1885-1915." Southern Cultures, Inaugural Issue (1993): 5-45.

Brownwell, Charles E., Calder Loth, William M. S. Rasmussen, and Richard Guy Wilson. The Making of Virginia Architecture. Richmond: Virginia Museum of Fine Arts, 1992.

Brundage, Fitzhugh W., ed. Where These Memories Grow: History, Memory, and Southern Identity. Chapel Hill: The University of North Carolina Press, 2000.

Carbone, Teresa A. and Patricia Hills, eds. Eastman Johnson: Painting America. Brooklyn: Brooklyn Museum of Art, 1999.

Cawelti, John G. "America on Display: The World's Fairs of 1876, 1893, 1933." In The Age of Industrialism in America, edited by Frederic Cople Jaher. New York: The Free Press, 1968.

Clark, Clifford Edward, Jr. The American Family Home, 1800-1960. Chapel Hill: The University of North Carolina Press, 1986.

Clinton, Catherine and Nina Silber, eds. Divided Houses: Gender and the Civil War. New York: Oxford University Press, 1992. 
Cohn, Jan. The Palace or the Poorhouse: The American House as a Cultural Symbol. East Lansing: The Michigan State University Press, 1979.

Conn, Steven. "Rescuing the Homestead of the Nation: The Mount Vernon Ladies' Association and the Preservation of Mount Vernon." Nineteenth Century Studies 11 (1997): 71-93.

Culhane, Kerri Elizabeth. "The Fifth Avenue of Richmond": The Development of the 800 and 900 Blocks of West Franklin Street, Richmond, Virginia, 1855-1925." Master's thesis, Virginia Commonwealth University, 1997.

Cutchins, John A. A Famous Command: The Richmond Light Infantry Blues. Richmond: Garrett and Massie, 1974.

Daily, Jane, Glenda Elizabeth Gilmore, and Bryant Simon, eds. Jumpin'Jim Crow: Southern Politics from Civil War to Civil Rights. Princeton: Princeton University Press, 2000.

Dalton, Robert E. and John E. Wells. The Virginia Architects: 1835-1955, A Biographical Dictionary. Richmond: New South Architectural Press, 1997.

Davis, Michael W. R. and Robert Schweitzer. Americas Favorite Homes. Detroit: Wayne State University Press, 1990.

Dalzell, Robert F., Jr. and Lee Baldwin Dalzell. George Washington's Mount Vernon: At Home in Revolutionary America. New York: Oxford University Press, 1998.

Deale, William. "Mount Vernon: An American Icon." Blueprints 21, no. 3 (Summer 2003): $1-3,16$.

Dimmick, Lauretta. "'An Altar Erected to Heroic Virtue Itself": Thomas Crawford and His 'Virginia Washington Monument." American Art Journal 23, no. 2 (1991): 4-73.

Emmet, Boris and John E. Jeuck. Catalogues and Counters: A History of Sears, Roebuck and Company. Chicago: The University of Chicago Press, 1950.

Fahs, Alice and Joan Waugh, eds. The Memory of the Civil War in American Culture. Chapel Hill: The University of North Carolina Press, 2004.

Faust, Drew Gilpin. "Race, Gender and Confederate Nationalism: William D.

Washington's Burial of Latané." The Southern Review (Spring 1989): 297-307.

Gaston, Paul M. The New South Creed: A Study in Southern Mythmaking. Montgomery: NewSouth Books, 1970. 
Gilbert, James, Neil Harris, Robert W. Rydell, and Wim de Wit. Grand Illusions: Chicago's World's Fair of 1893. Chicago: Chicago Historical Society, 1993.

Greenberg, Allan. George Washington: Architect. New York: Andreas Papadakis, Publisher, 1999.

Gwinn, Nancy and Robert W. Rydell. Fair Representations. Amsterdam: VU University Press, 1994.

Halbwachs, Maurice. The Collective Memory. Translated by Francis J. Ditter, Jr. and Vida Yazdi Ditter. New York: Harper and Row, 1980.

Hamlin, Talbot Faulkner. The American Spirit in Architecture. New Haven: Yale University Press, 1926.

Hills, Patricia. The Genre Painting of Eastman Johnson: The Sources and Development of His Styles and Themes. New York: Garland Publishing, 1977.

Hosmer, Charles B., Jr. Presence of the Past; A History of the Preservation Movement in the United States Before Williamsburg. New York: G. P. Putnam's Sons, 1965.

Kammen, Michael. Mystic Chords of Memory: The Transformation of Tradition in American Culture. New York: Alfred A. Knopf, 1991.

-----. A Season of Youth: The American Revolution and the Historical Imagination. New York: Alfred A. Knopf, 1978.

King, Grace Elizabeth. Mount Vernon on the Potomac: History of the Mount Vernon Ladies' Association of the Union. New York: The Macmillan Company, 1929.

Lee, Jean B. "Historical Memory, Sectional Strife, and the American Mecca, Mount Vernon, 1783-1853." Virginia Magazine of History and Biography 109, no. 3 (2001): 255-300.

Lindgren, James M. Preserving the Old Dominion: Historic Preservation and Virginia Traditionalism. Charlottesville: University Press of Virginia, 1993.

----. "“A Spirit That Fires the Imagination:' Historic Preservation and Cultural Regeneration in Virginia and New England, 1850-1950." In Giving Preservation a History: Histories of Historic Preservation in the United States, edited by Randall Mason and Max Page. New York: Routledge, 2004.

Mahone, Elizabeth. "Edgerton Stewart Rogers, 1860-1901." Student Paper, Maymont Internship, 23 March 1988. 
Marling, Karal Ann. George Washington Slept Here: Colonial Revivals and American Culture, 1876-1986. Cambridge: Harvard University Press, 1988.

May, Bridget. "Progressivism and the Colonial Revival: The Modern Colonial House, 1900-1920." Winterthur Portfolio 26, no. 2/3 (Summer - Autumn 1991): 107-22.

McInnis, Maurie and the Students of the Fall 2005 seminar "American Art and Memory," The University of Virginia.

Mills, Cynthia and Pamela A. Simpson, eds. Monuments to the Lost Cause: Women, Art, and the Landscapes of Southern Memory. Knoxville: University of Tennessee Press, 2003.

Mitnick, Barbara J., ed. George Washington: American Symbol. New York: Hudson Hills Press, 1999.

Mjagkij, Nina and Margaret Spratt, eds. Men and Women Adrift: The YMCA and YWCA in the City. New York: New York University Press, 1997.

Morgan, John Hill. Paintings by John Trumbull at Yale University of Historic Scenes and Personages Prominent in the American Revolution. New Haven: Yale University Press, 1926.

Munford, Robert B., Jr. Richmond Homes and Memories. Richmond: Garrett \& Massie, Inc., 1936.

Peterson, Merrill D. The Jefferson Image in the American Mind. New York: Oxford University Press, 1960.

Rabinowitz, Howard N. "George Washington as Icon: 1865-1900." In Icons of America, edited by Ray B. Browne and Marshall Fishwick. Bowling Green: Popular Press, 1978.

Rasmussen, William M. S. and Robert S. Tilton, eds. George Washington: The Man Behind the Myths. Charlottesville: University Press of Virginia, 1999.

Rhoads, William B. The Colonial Revival. New York: Garland Publishing, 1977.

----. "The Colonial Revival and American Nationalism." The Journal of the Society of Architectural Historians 35, no. 4 (December 1976): 239-254.

Rhodes, Marylou. Landmarks of Richmond: Places to Know and See in the Nation's Most Historic City. Richmond: Garrett and Massie, 1938.

Rogers, Millard F., Jr. Randolph Rogers: American Sculptor in Rome. Cambridge: The University of Massachusetts Press, 1971. 
Rydell, Robert W. All the World's a Fair: Visions of Empire at American International Expositions, 1876-1916. Chicago: The University of Chicago Press, 1984.

-----. “A Cultural Frankenstein? The Chicago World's Columbian Exposition of 1893." In American Architectural History: A Contemporary Reader, edited by Keith L. Eggener. London: Routledge, 2004.

----. World of Fairs: The Century-Of-Progress Expositions. Chicago: University of Chicago Press, 1993.

Savage, Kirk. Standing Soldiers, Keeling Slaves: Race, War and Monument in Nineteenth-Century America. Princeton: Princeton University Press, 1997.

Schiller, Joyce K. "Nydia: A Forgotten Icon of the Nineteenth Century." Bulletin of the Detroit Institute of Arts 67, no. 4 (1993): 37-45.

Scully, Vincent J., Jr. The Shingle Style: Architectural Theory and Design from Richardson to the Origins of Wright. New Haven: Yale University Press, 1955.

Sears, Roebuck and Company. Sears Archives. 1 March 2005. $<$ http://www.searsarchives.com/> October - December 2005.

Stevenson, Katherine Cole. Houses by Mail: A Guide to Houses from Sears, Roebuck and Company. Washington, D.C.: Preservation Press, 1986.

Strayer, Martha. The D.A.R.: An Informal History. Washington, D. C.: Public Affairs Press, 1958.

Taylor, Robert T. "The Jamestown Tercentennial Exposition of 1907," The Virginia Magazine of History and Biography 65, no. 2 (April 1957): 169-208.

Varon, Elizabeth R. We Mean to Be Counted: White Women and Politics in Antebellum Virginia. Chapel Hill: The University of North Carolina Press, 1998.

Weiman, Jeanne Madeline. The Fair Women: The Story of the Women's Building, World's Columbian Exposition, Chicago 1893. Chicago: Academy Chicago, 1981.

West, Patricia. Domesticating History: The Political Origins of America's House Museums. Washington: Smithsonian Institution Press, 1999.

Wills, Gary. Cincinnatus: George Washington and the Enlightenment: Images of Power in Early America. New York: Doubleday \& Co., 1984. 
Wilson, Richard Guy. "Building on the Foundations: The Historic Present in Virginia Architecture, 1870-1990." In The Making of Virginia Architecture. Richmond: Virginia Museum of Fine Arts, 1992.

-----. The Colonial Revival House. New York: Harry N. Abrams, Inc., 2004.

Wright, Gwendolyn. Building the Dream: A Social History of Housing in America. New York: Pantheon Books, 1981. 
Wilson, Richard Guy. "Building on the Foundations: The Historic Present in Virginia Architecture, 1870-1990." In The Making of Virginia Architecture. Richmond: Virginia Museum of Fine Arts, 1992.

-----. The Colonial Revival House. New York: Harry N. Abrams, Inc., 2004.

Wright, Gwendolyn. Building the Dream: A Social History of Housing in America. New York: Pantheon Books, 1981. 

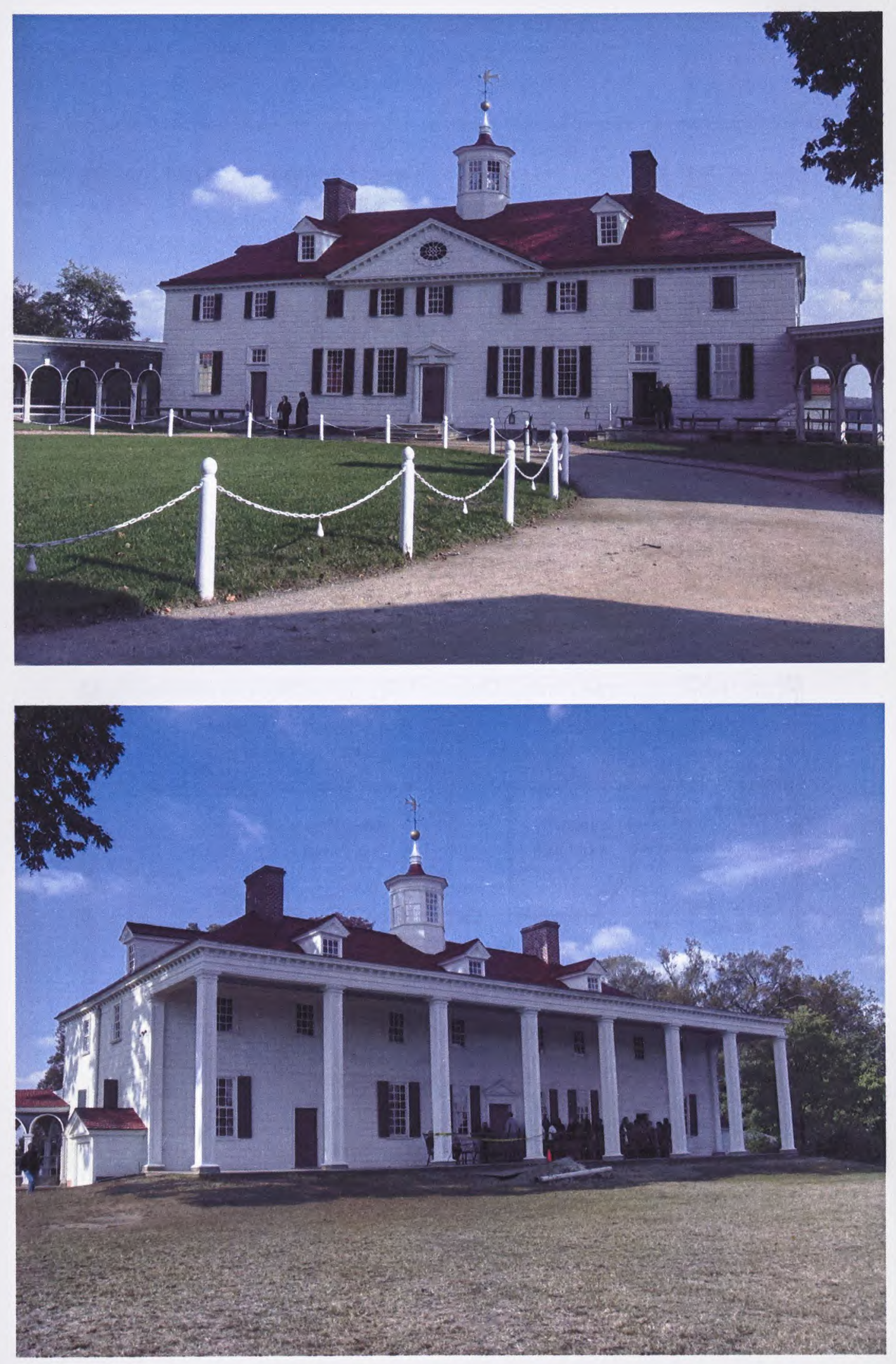

Figures 1 and 2. Land (west) and Potomac (east) elevations of Mount Vernon in Virginia. 

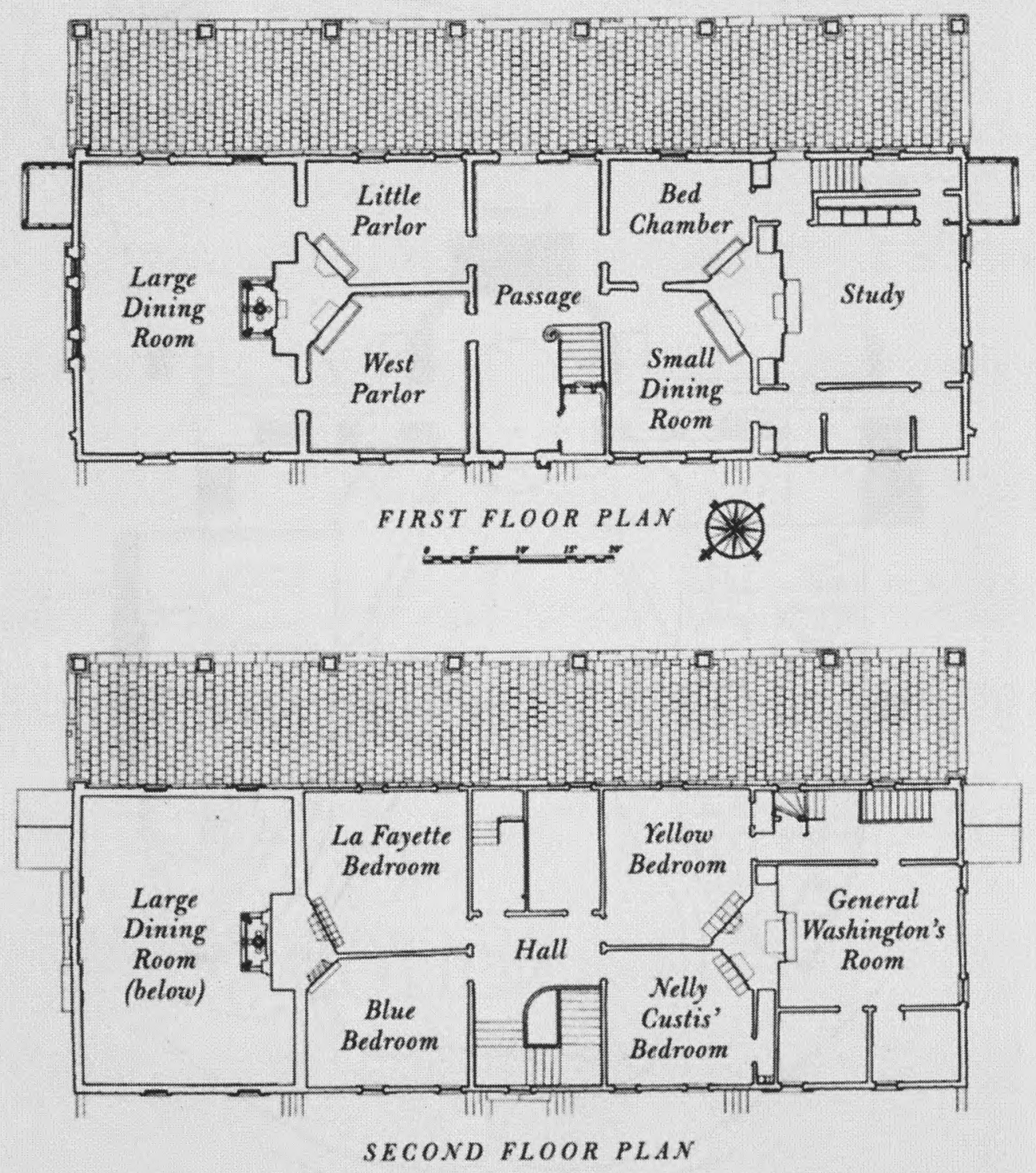

Figure 3. Plan of Mount Vernon's first and second floors. 


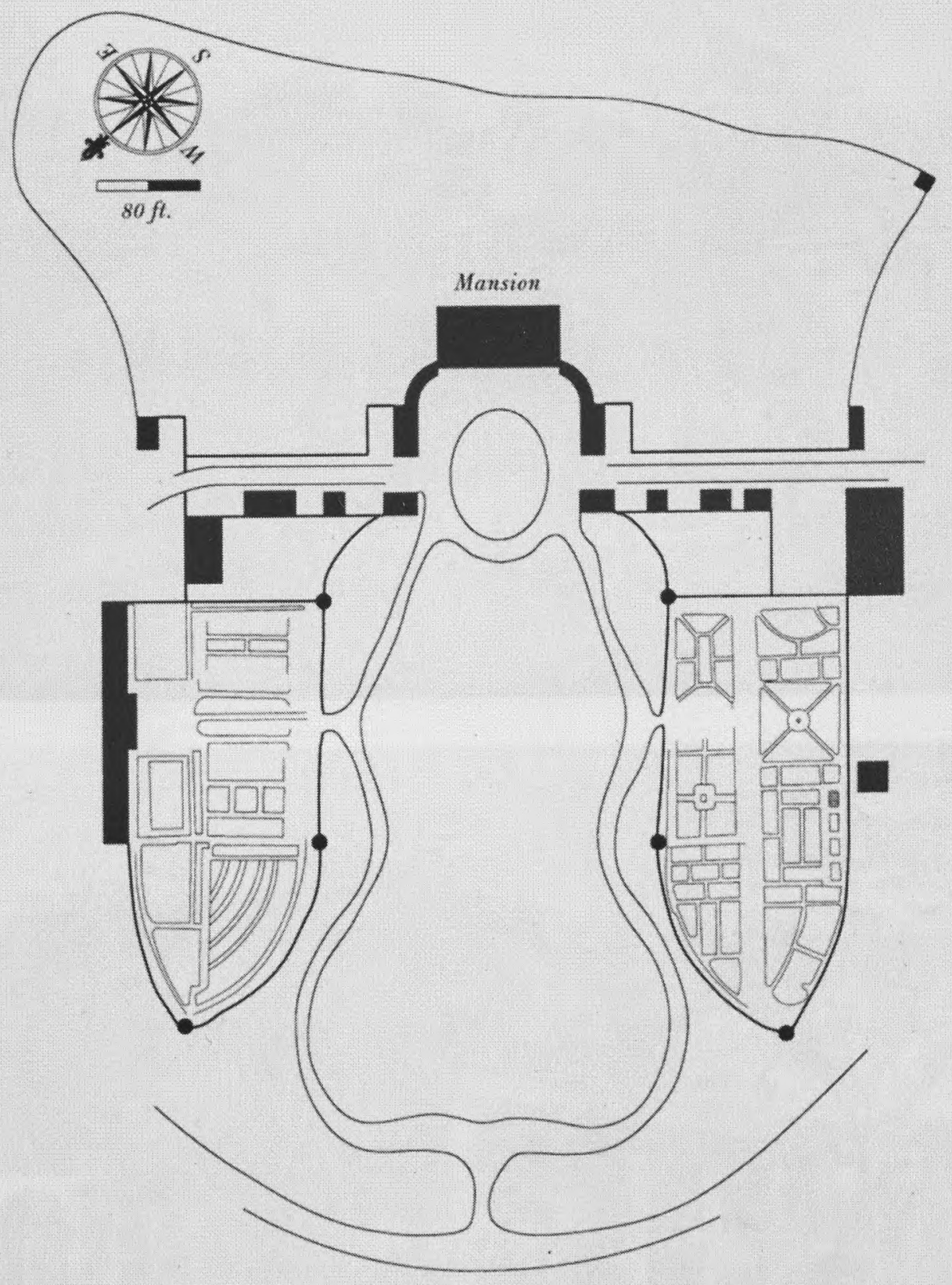

Figure 4. Site plan of Mount Vernon, showing subsidiary service structures. Note especially the kitchen and servants hall, to the right and left of the main mansion, respectively. 

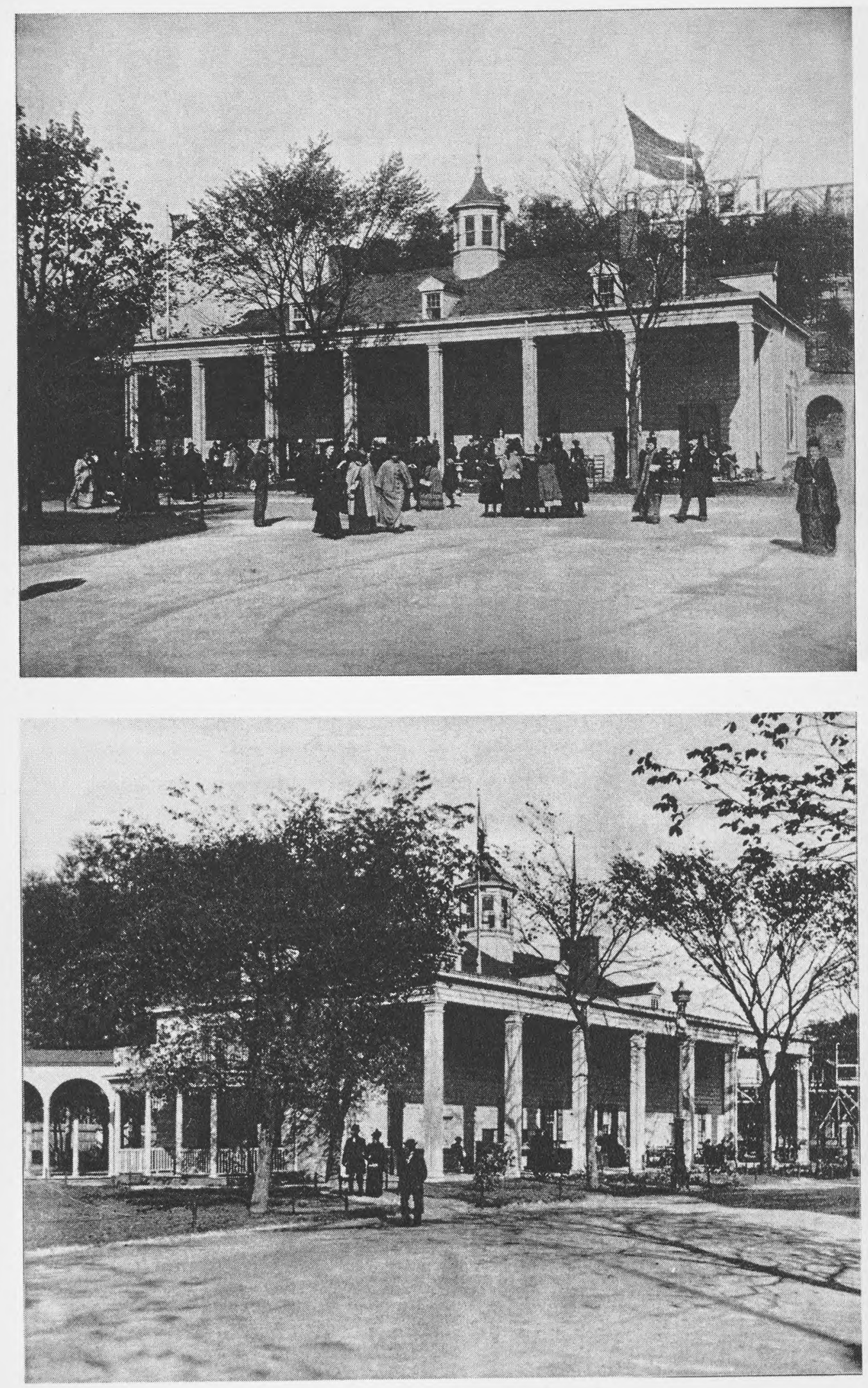

Figures 5 and 6. The Virginia Building at the 1893 World's Columbian Exposition, designed by Edgerton Stewart Rogers. 

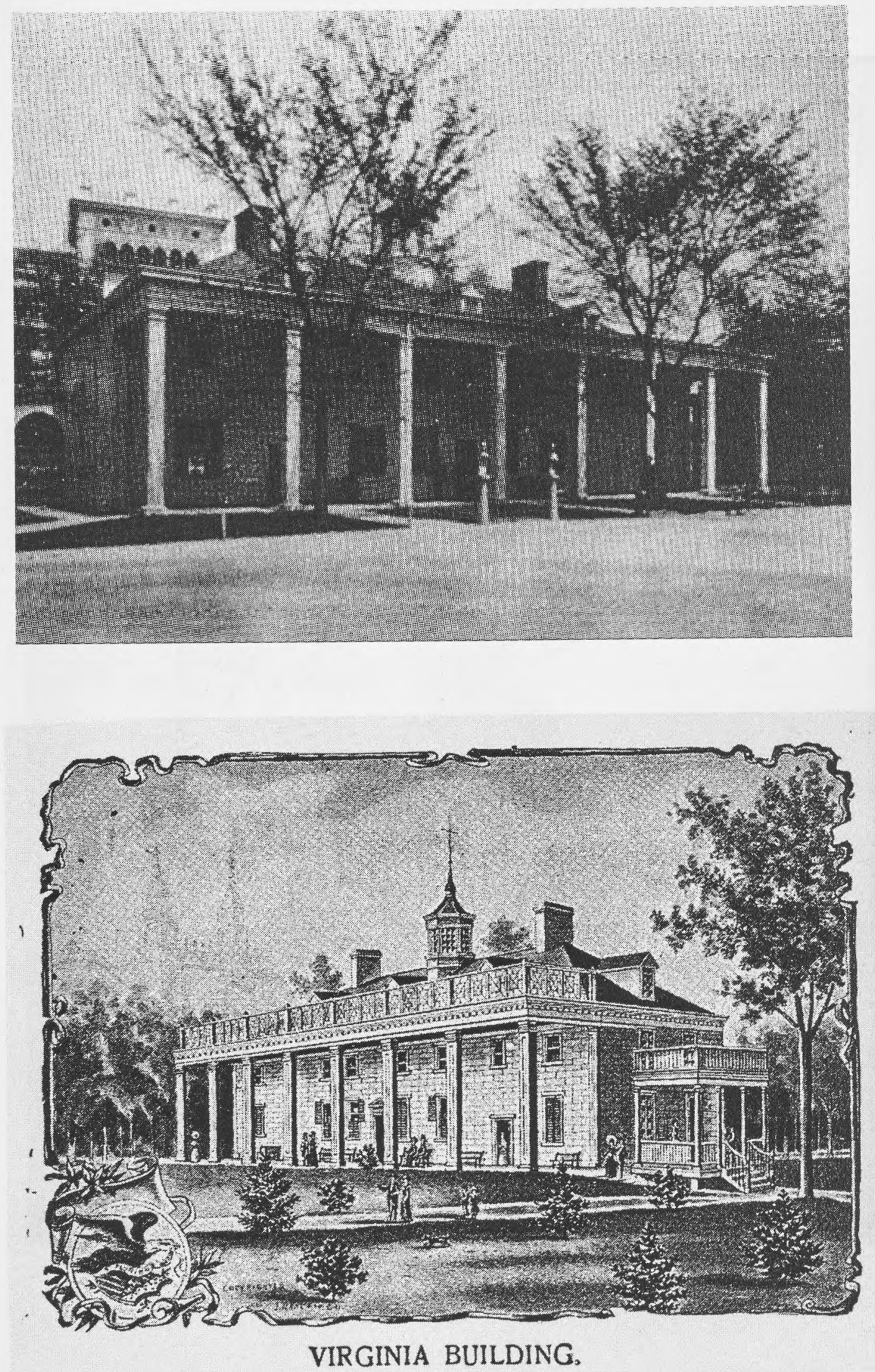

Figures 7 and 8. The 1893 Virginia Building. 


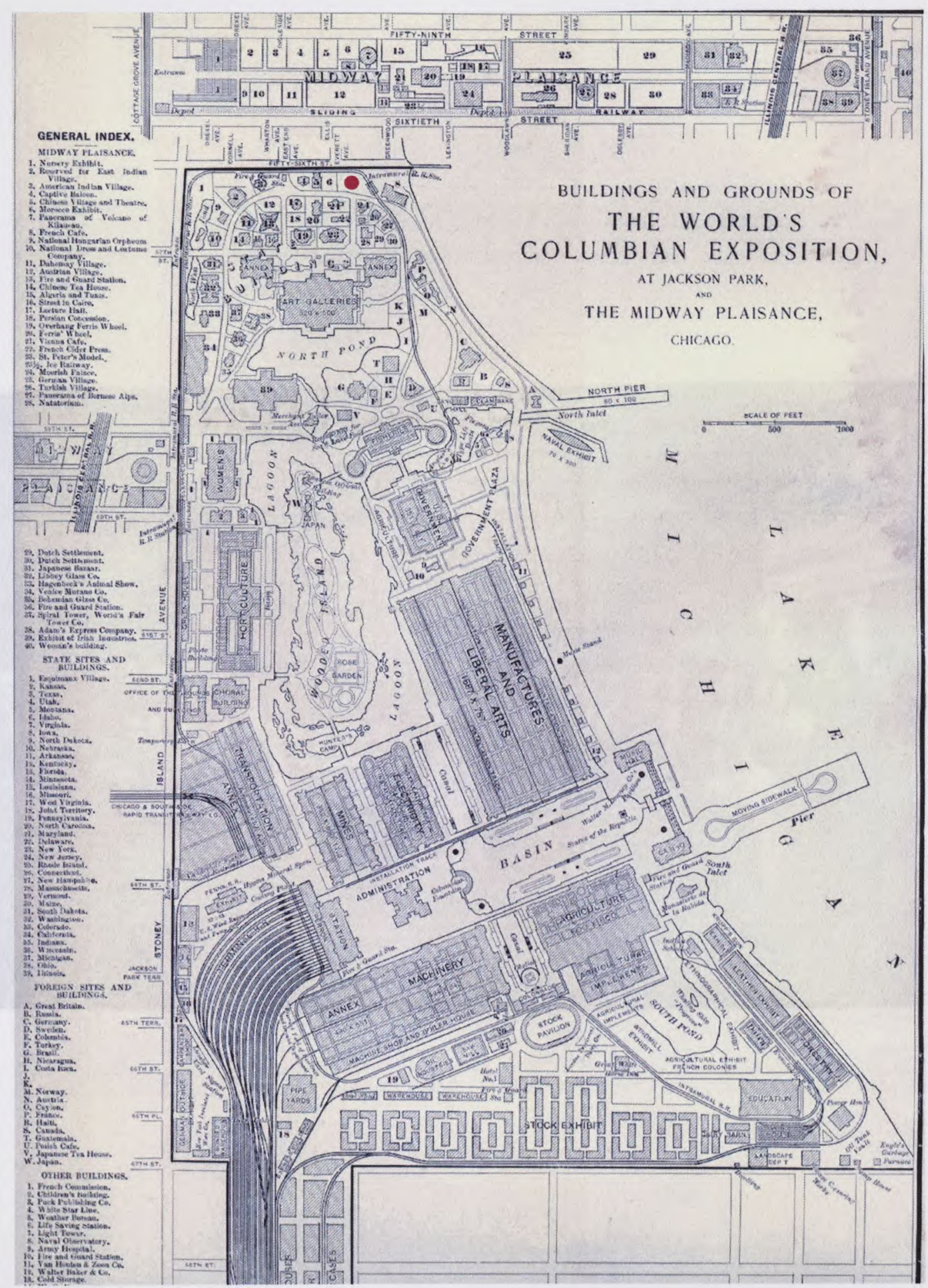

Figure 9. Map of the Exposition grounds. The red dot represents the location of the Virginia Building. 


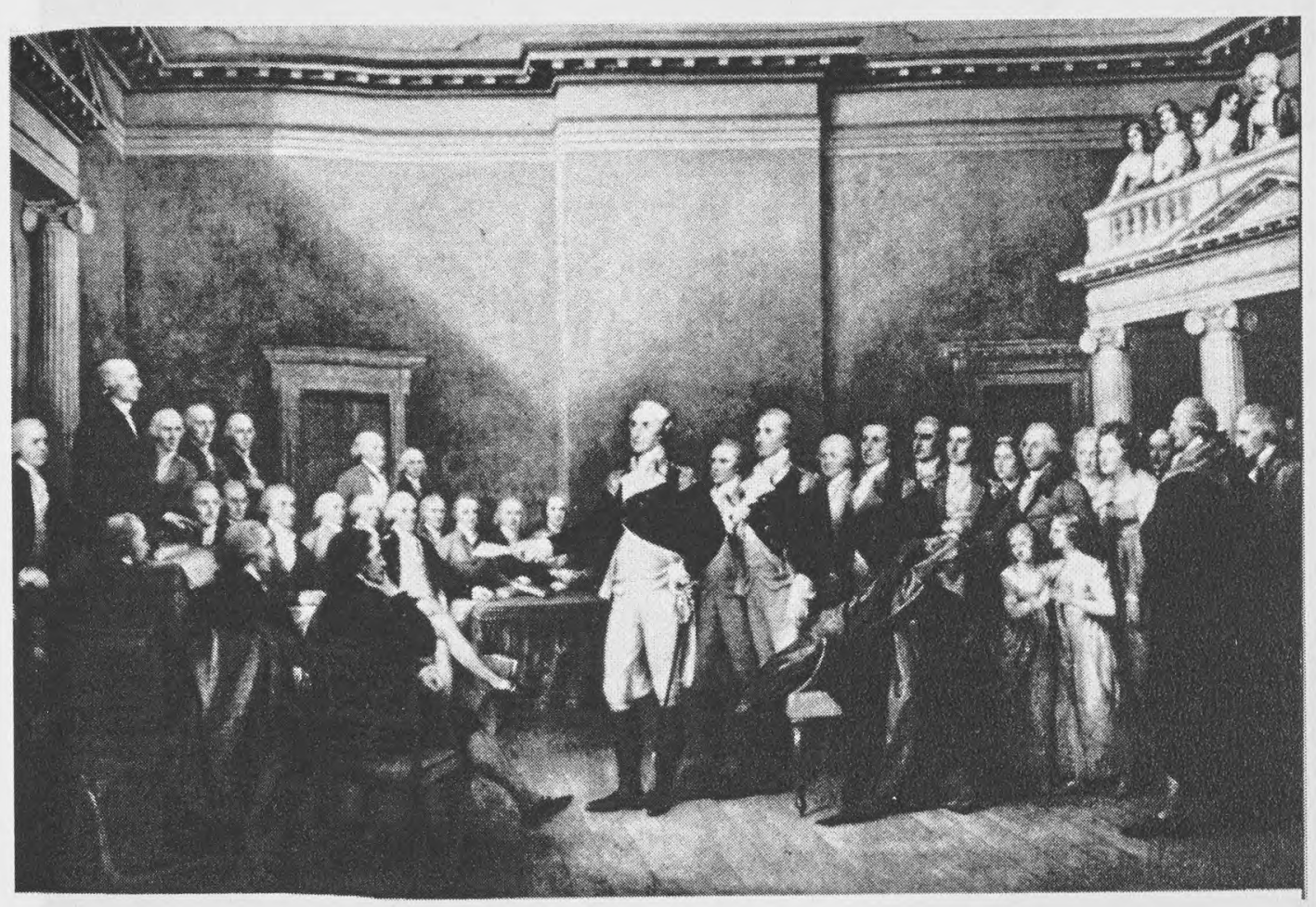

Figure 10. John Trumbull, "The Resignation of George Washington," 182428 , oil on canvas. 


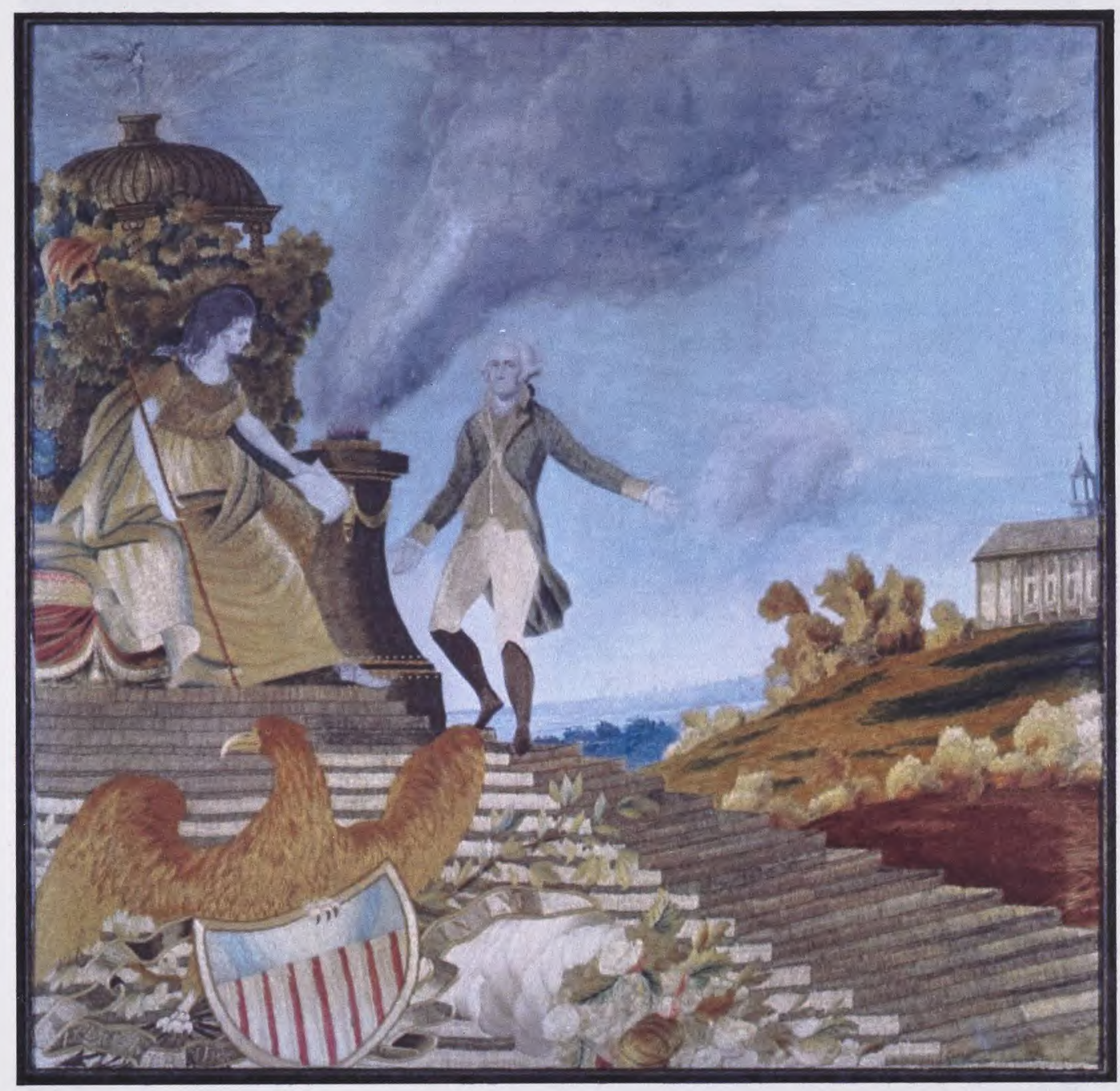

Figure 11. "George Washington's Resignation,” circa 1799. Engraving published by Benjamin Davies based on a drawing by John James Barralet. 


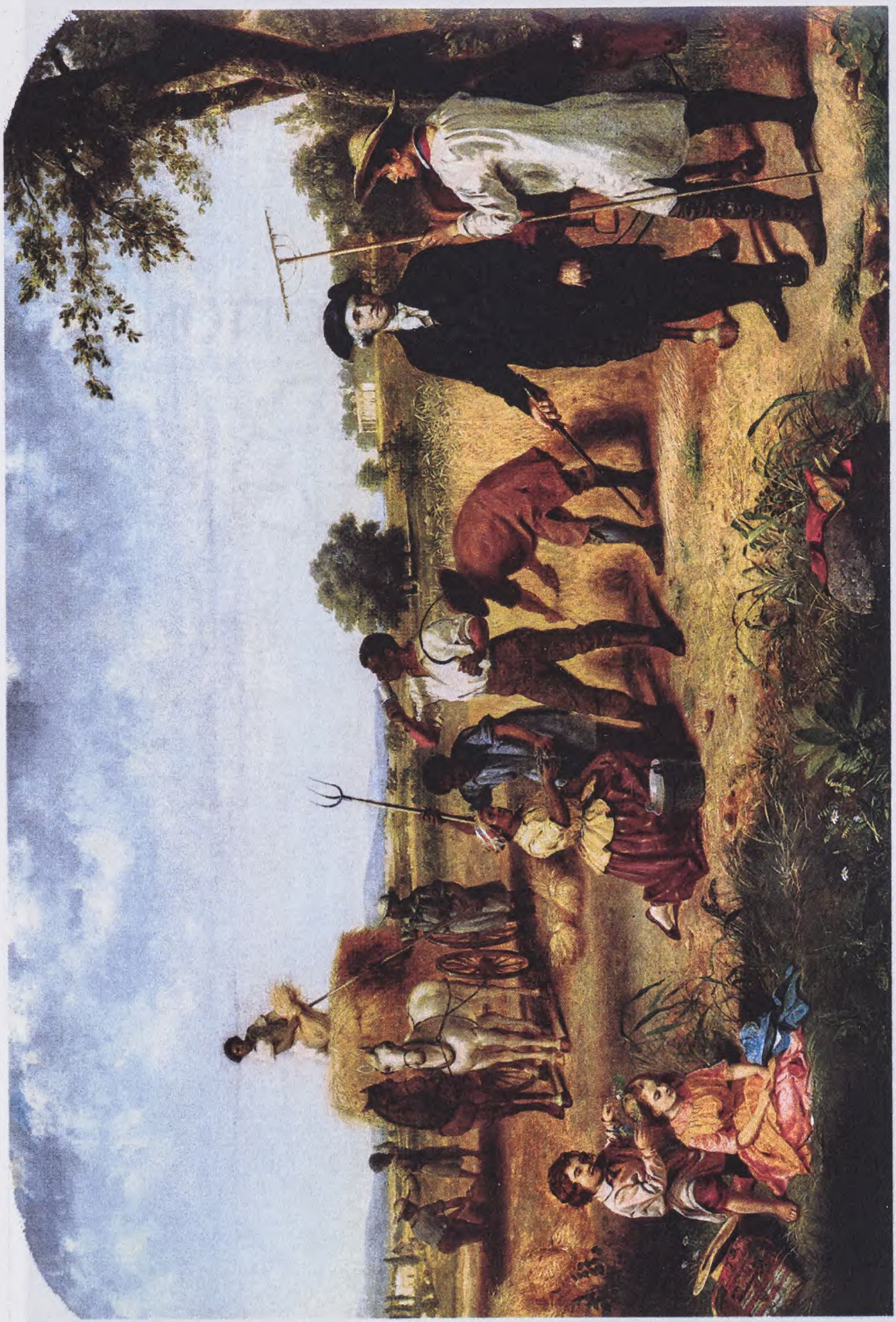

Figure 12. Junius Brutus Stearn, "Washington as a Farmer at Mount Vernon," 1851, oil on canvas. 


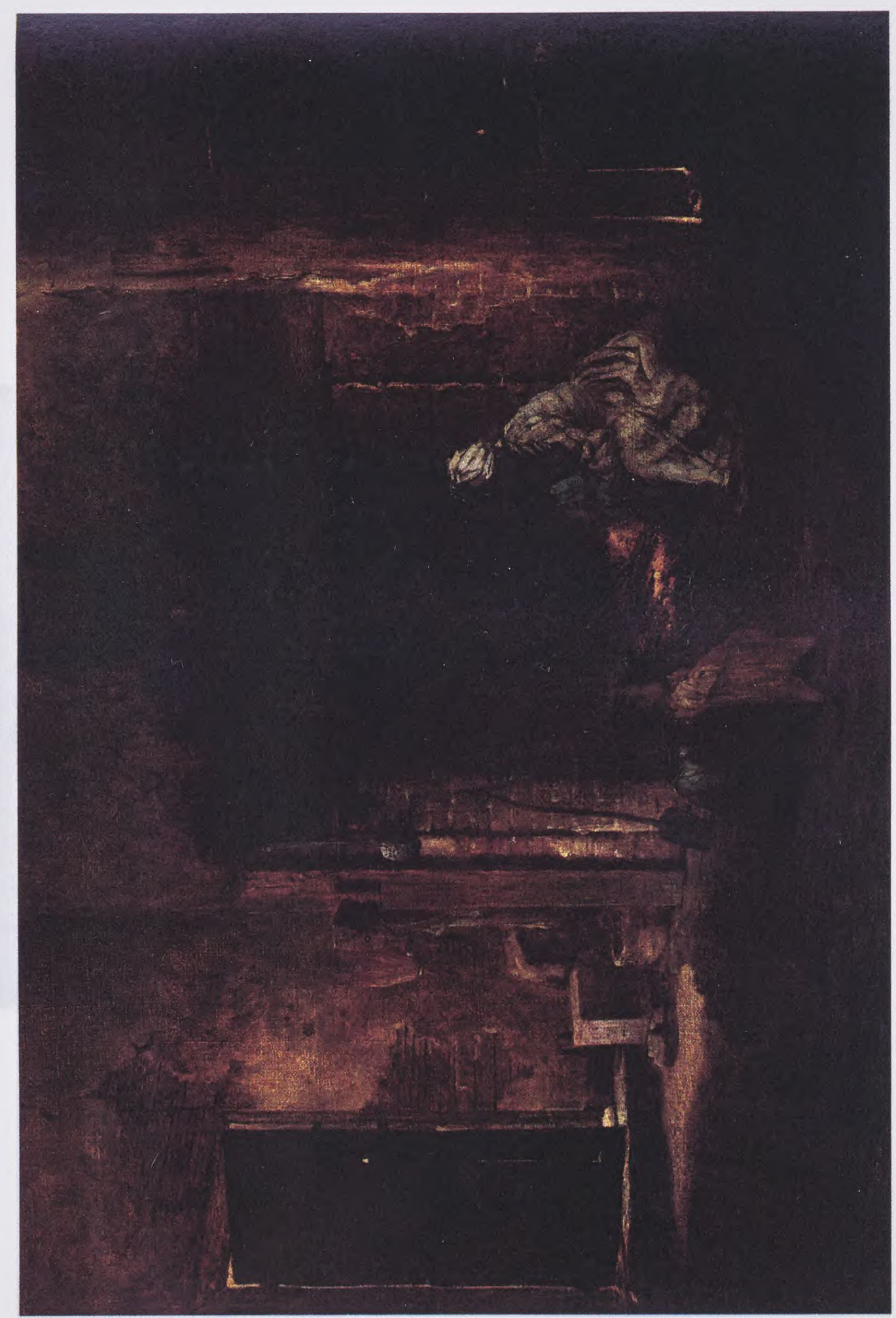

Figure 13. Eastman Johnson, "Mount Vernon Kitchen,” 1857, oil on canvas. 


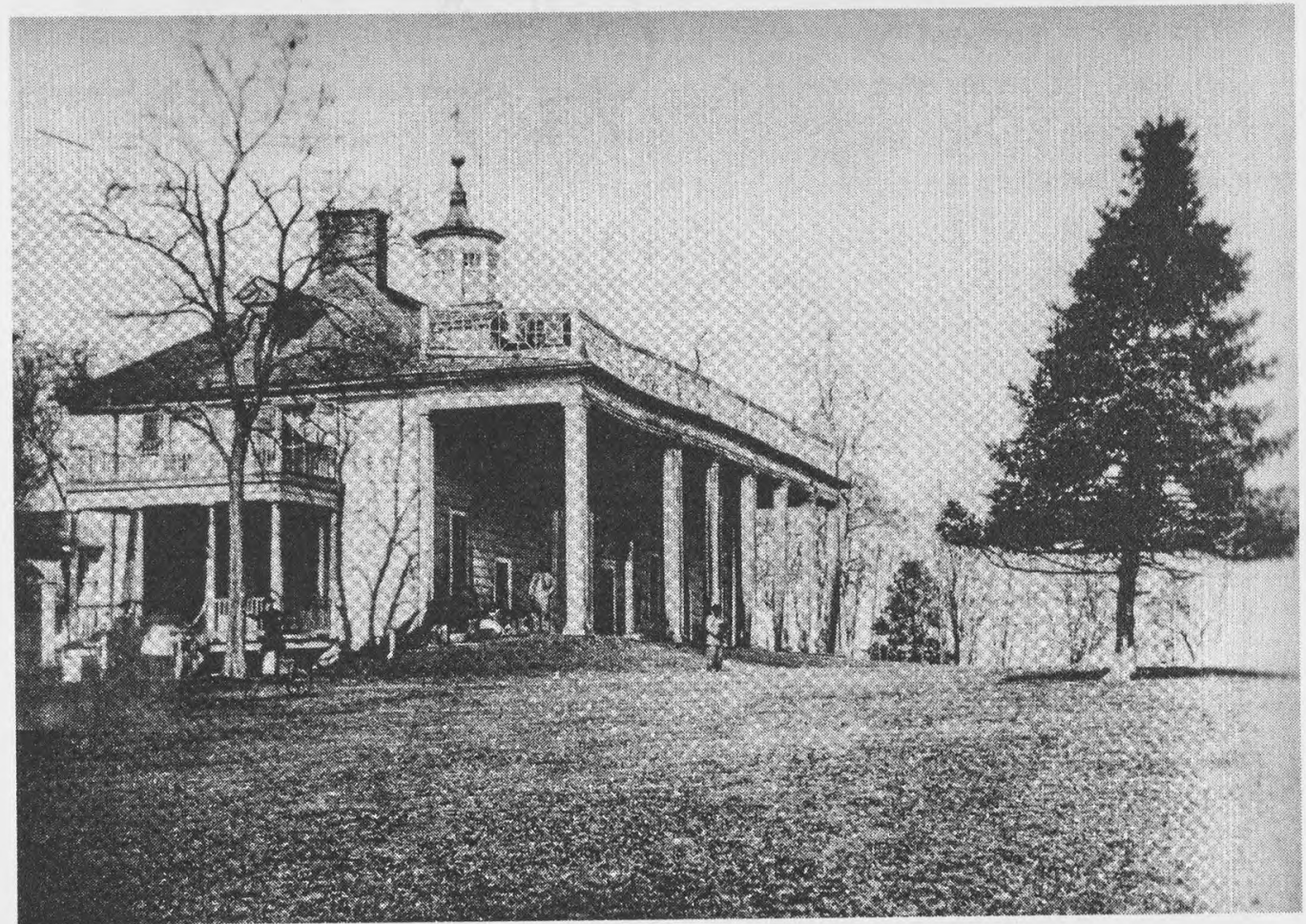

Figure 14. The ruined state of Mount Vernon in the $1850 \mathrm{~s}$. 


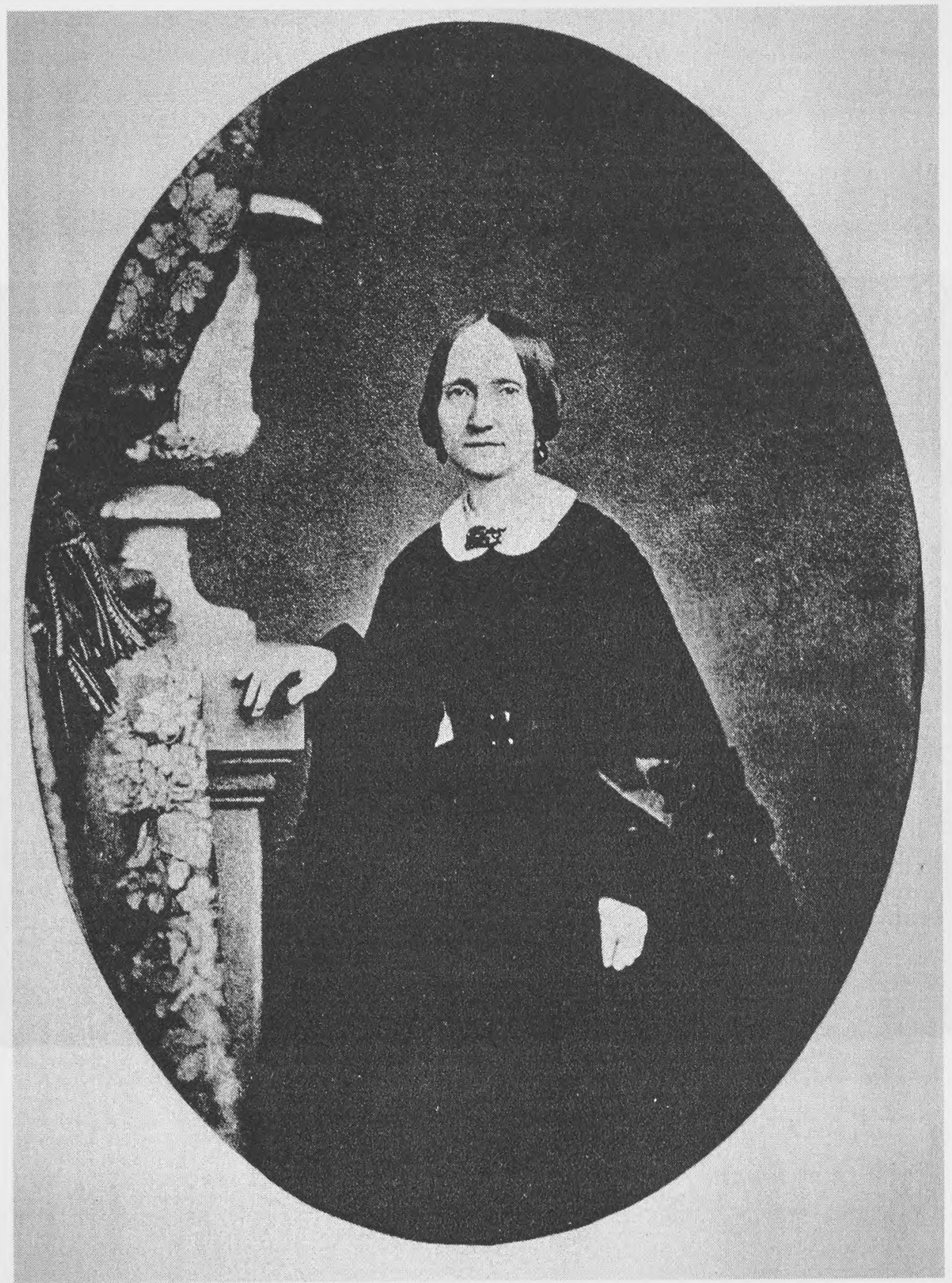

Figure 15. Ann Pamela Cunningham, founder of the Mount Vernon Ladies' Association. 


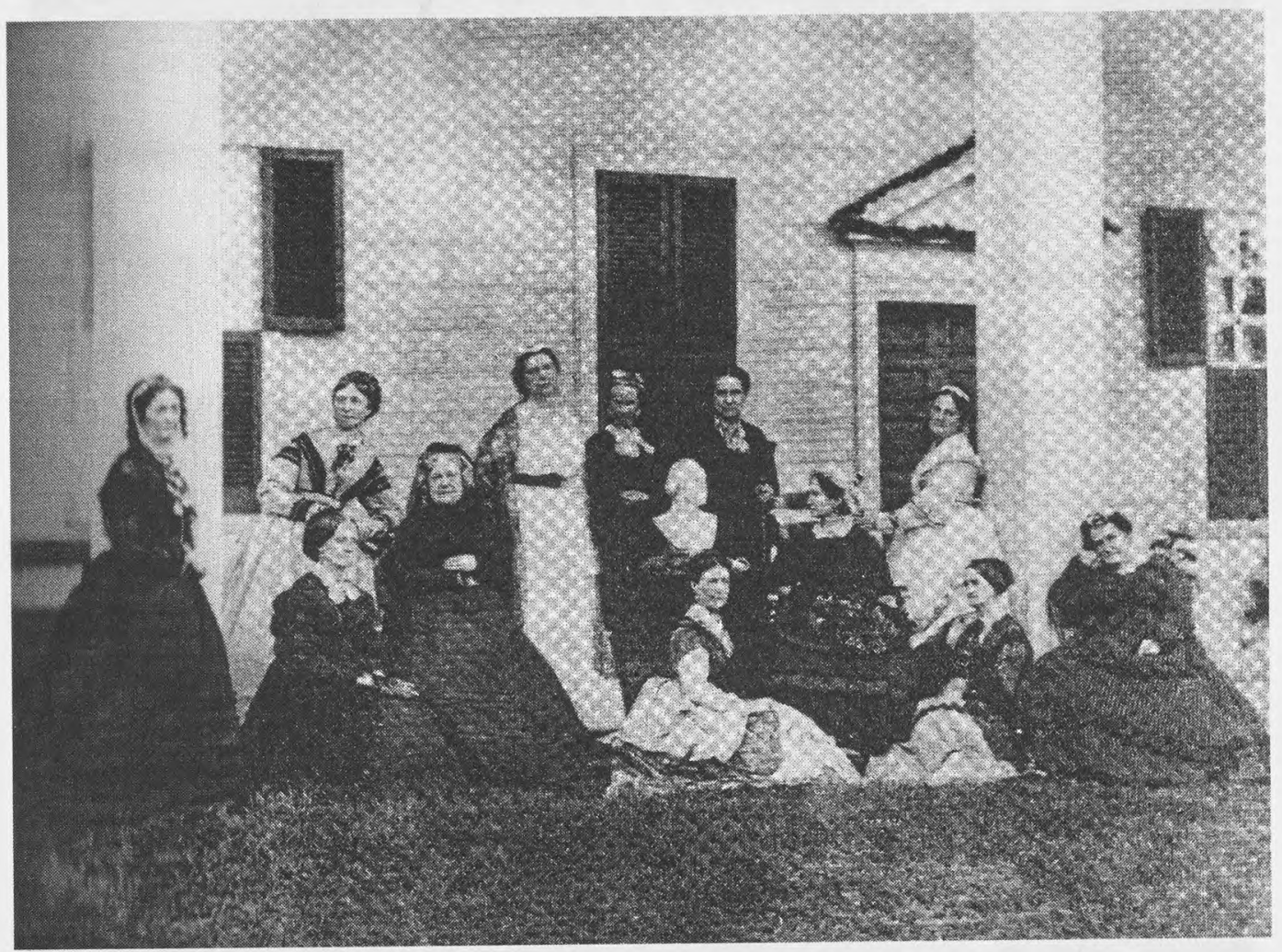

Figure 16. The Mount Vernon Ladies Association on the steps of Mount Vernon c. 1873, with Ann Pamela Cunningham seated and looking to the bust of Washington to her right. 

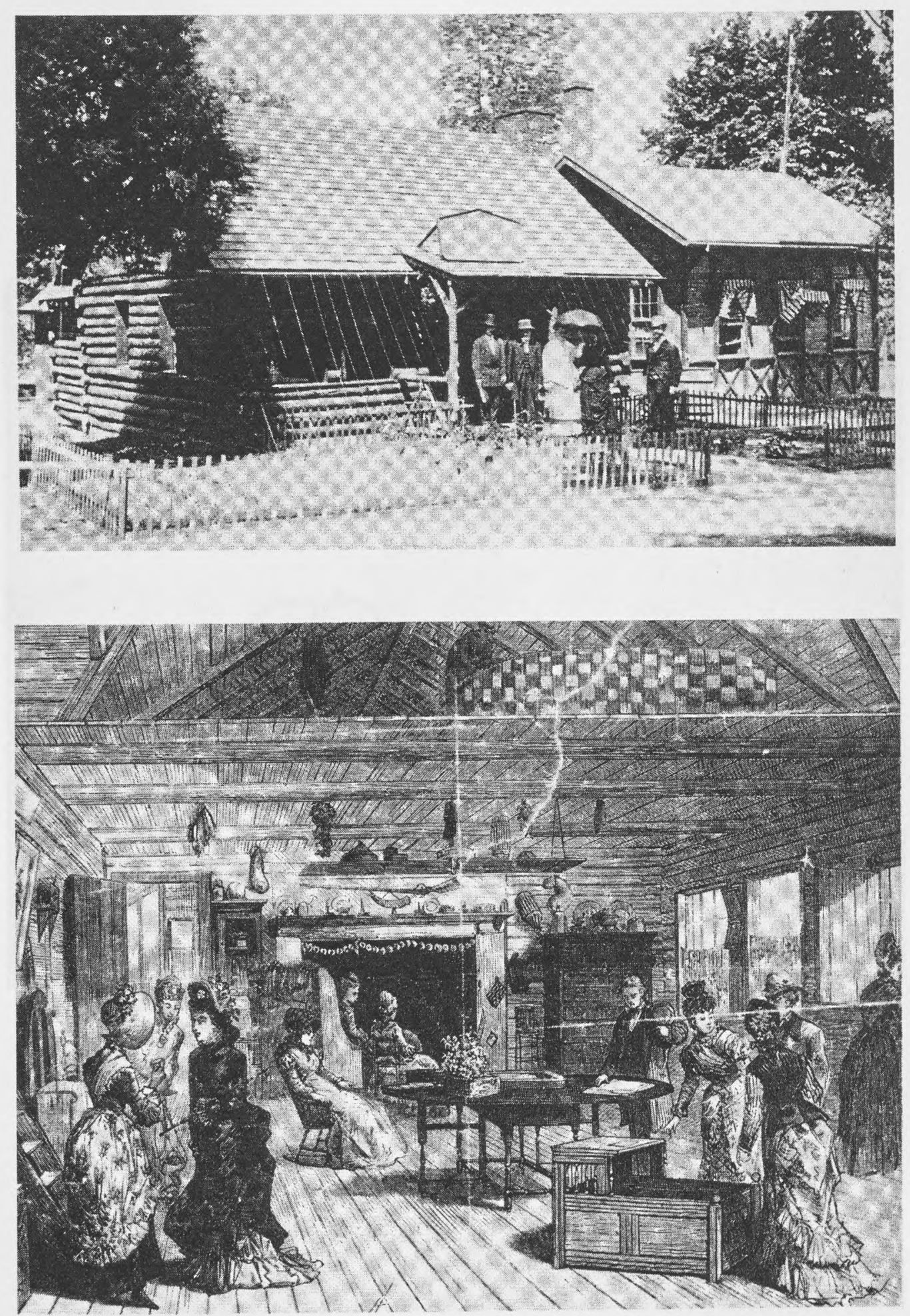

Figures 17 and 18. The "New England Log-House" at the 1876 Philadelphia Centennial. 


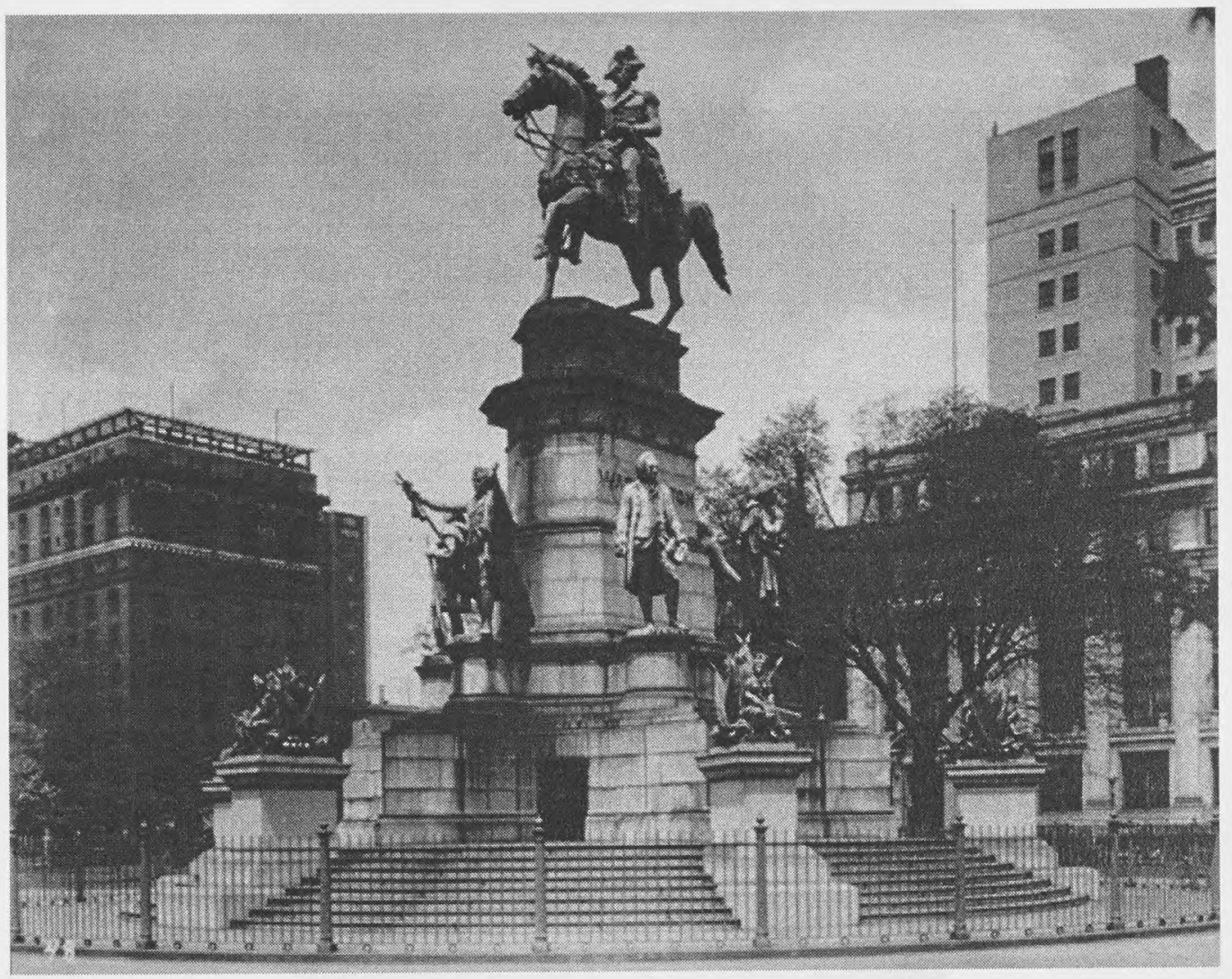

Figure 19. Equestrian Statue of George Washington, Richmond, Virginia, begun in 1849 by Thomas Crawford and later finished by Randolph Rogers. 


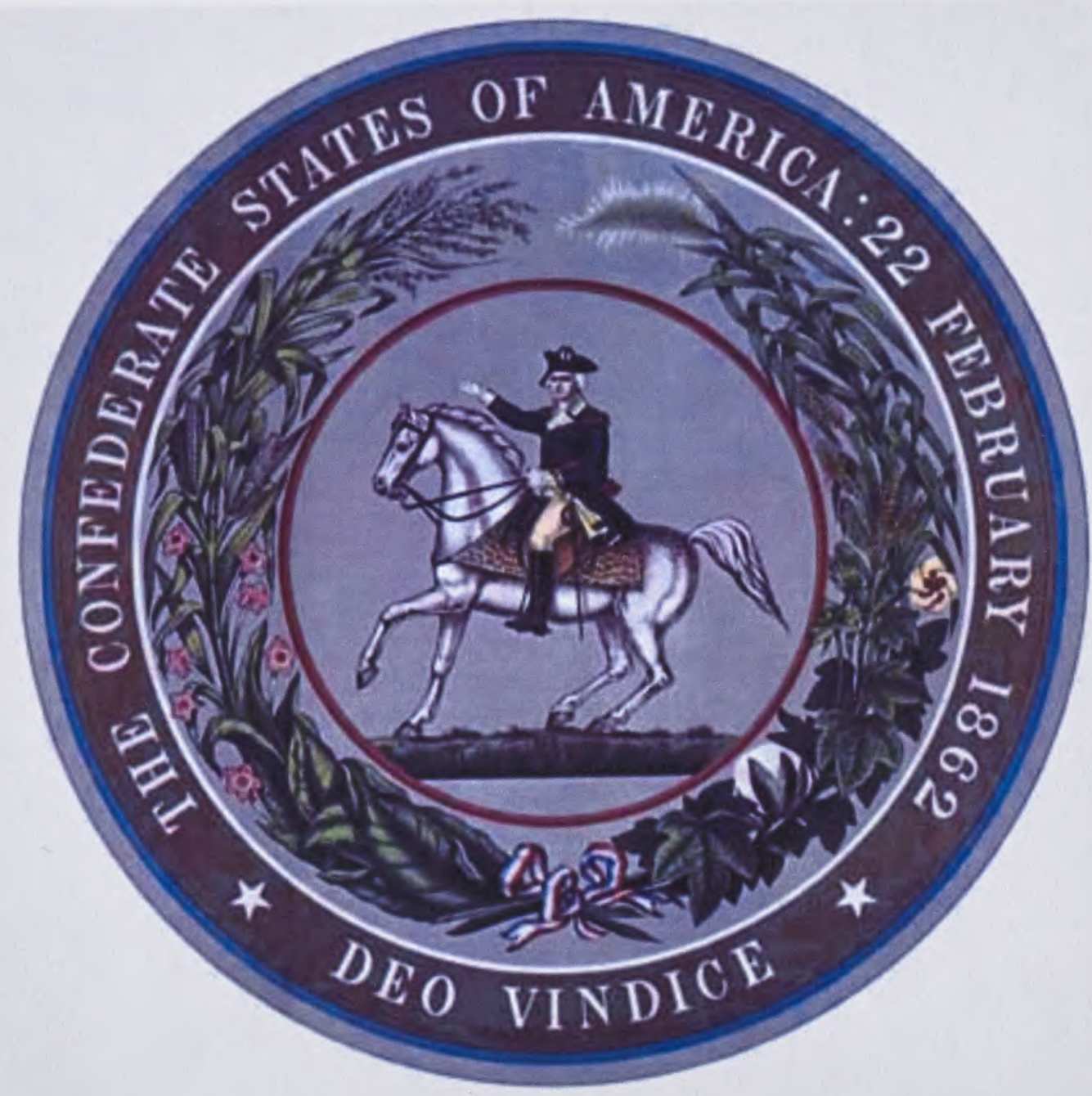

Figure 20. Seal of the Confederate States of America. 


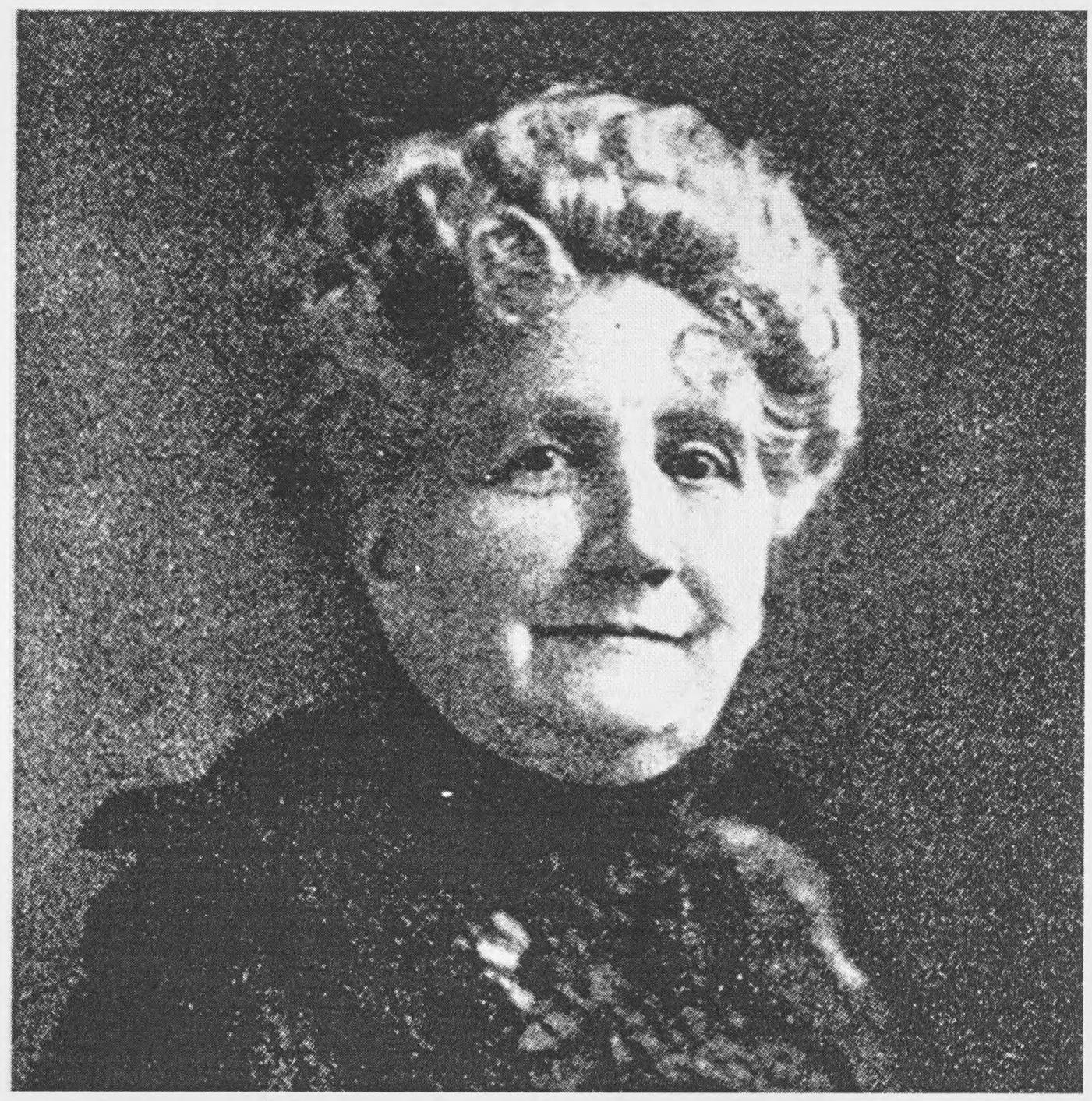

Figure 21. Lucy Preston Beale. 


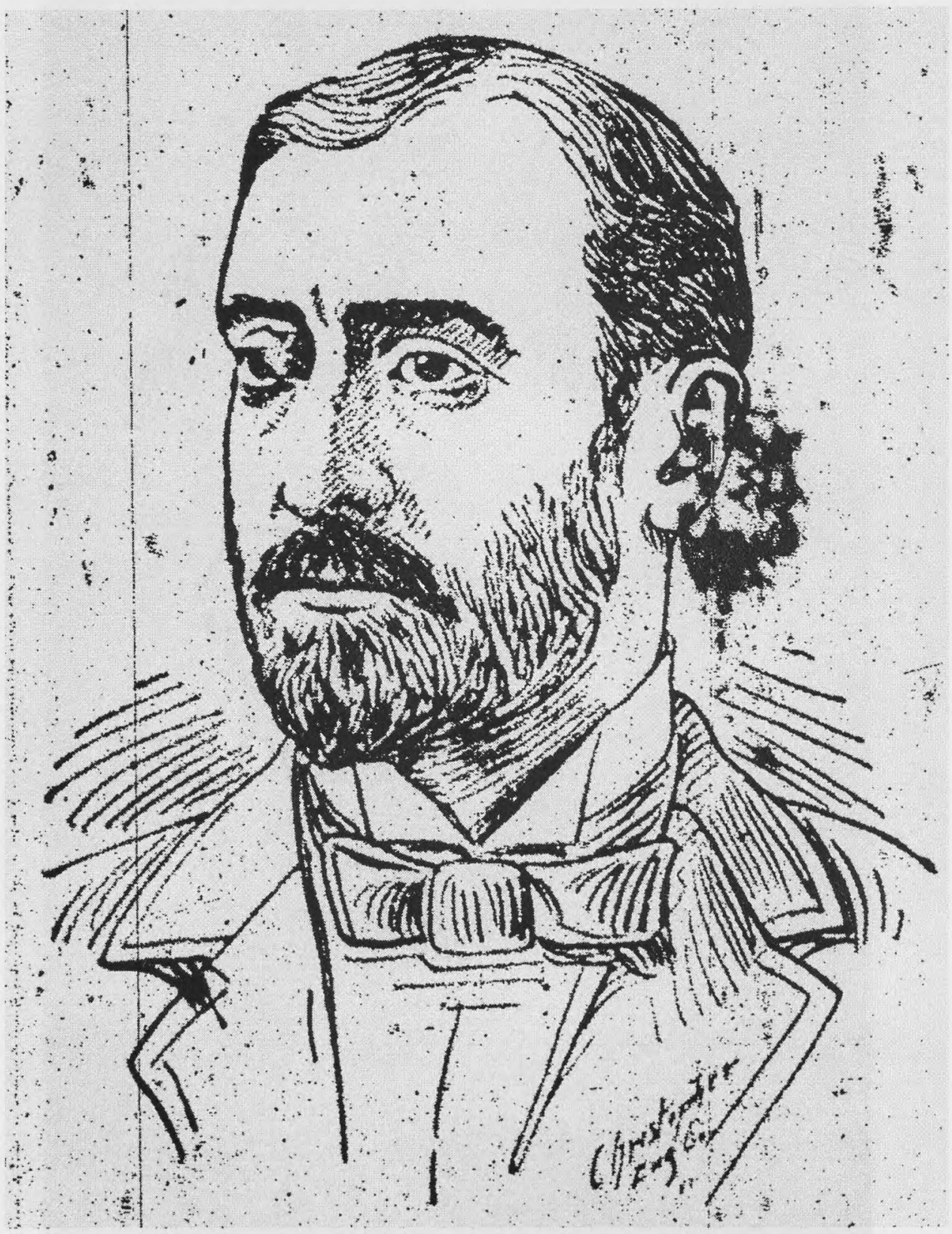

Figure 22. Edgerton Stewart Rogers. 


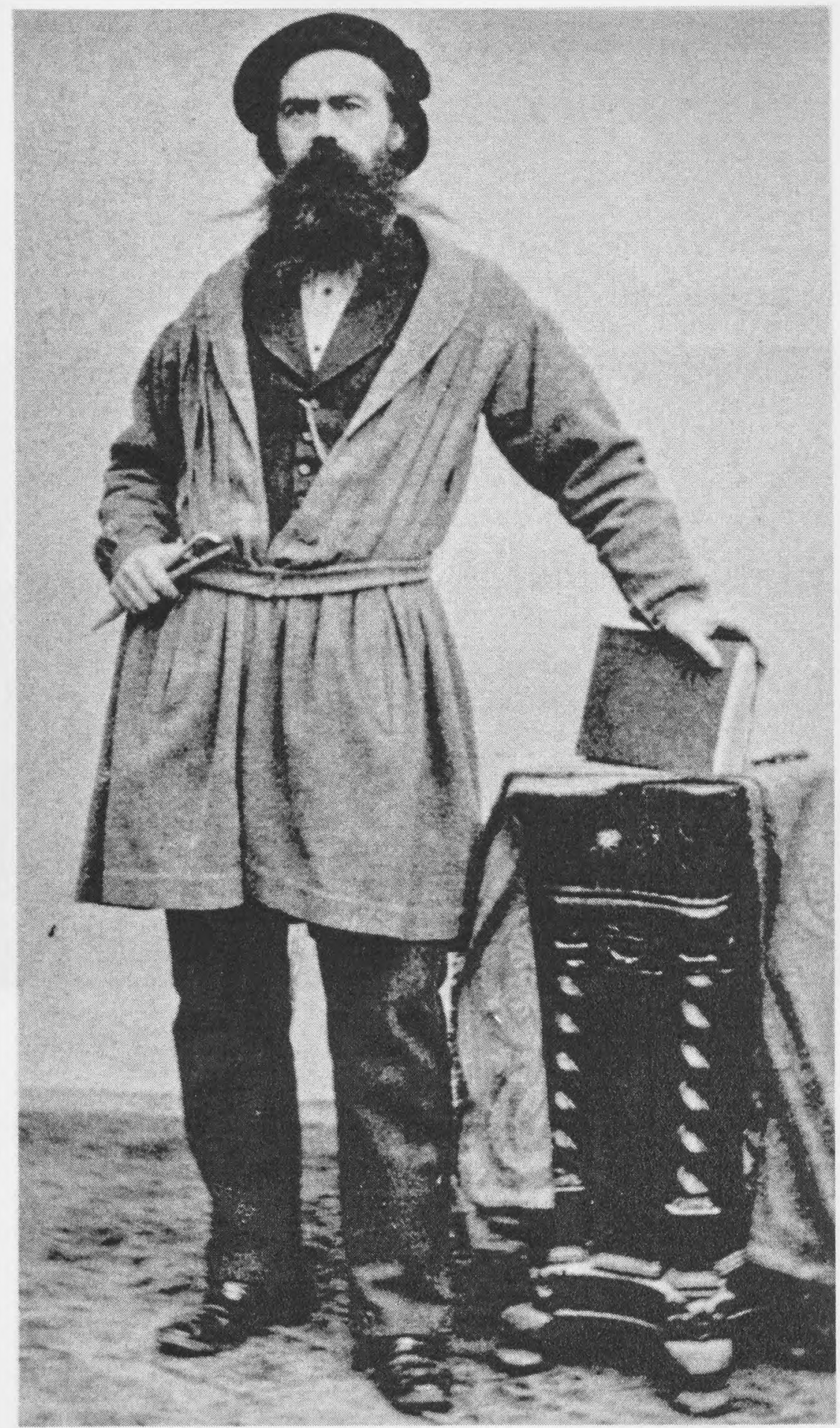

Figure 23. Randolph Rogers, Edgerton Stewart Rogers's father. 


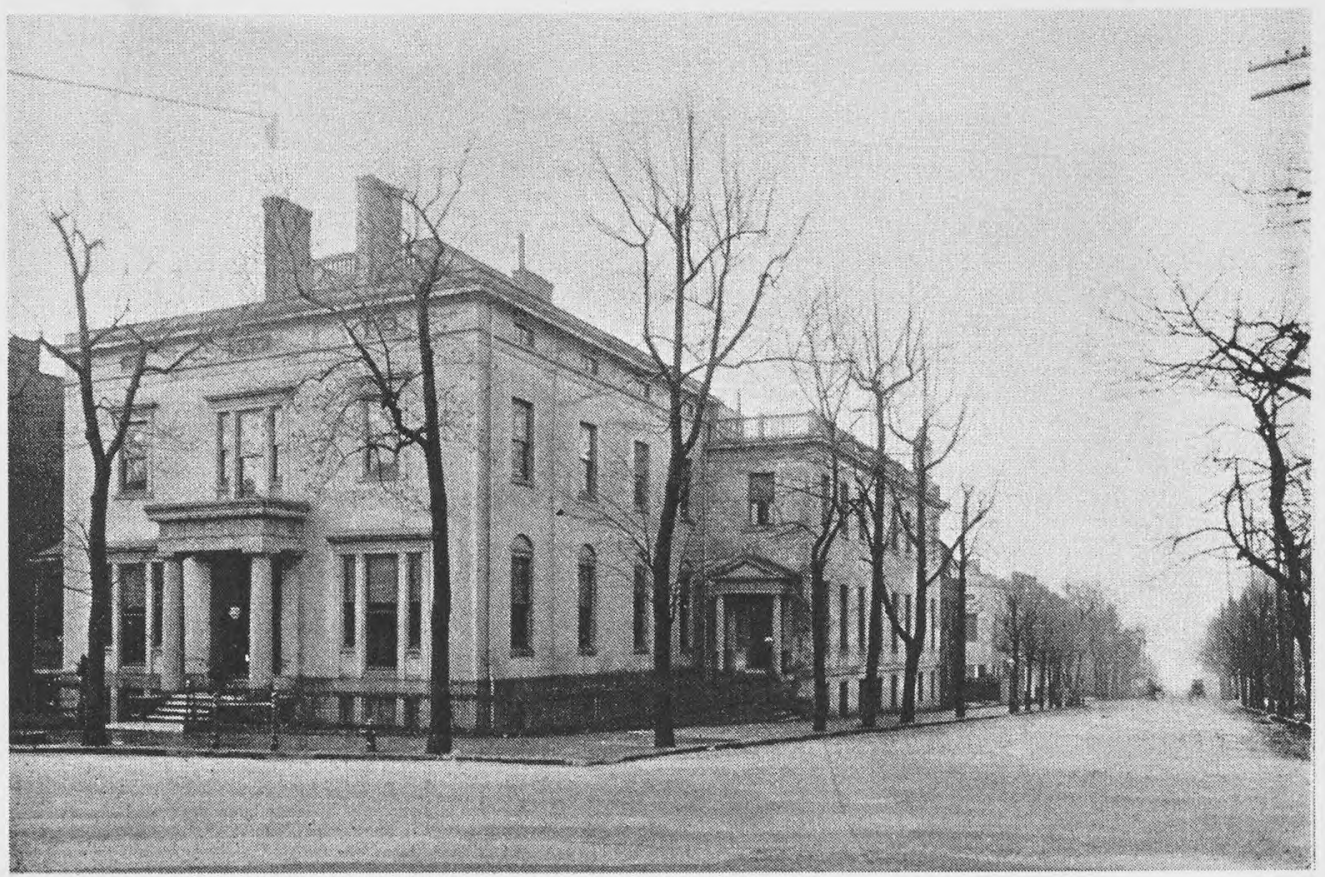

Figure 24. The Westmoreland Club, Richmond, Virginia. 


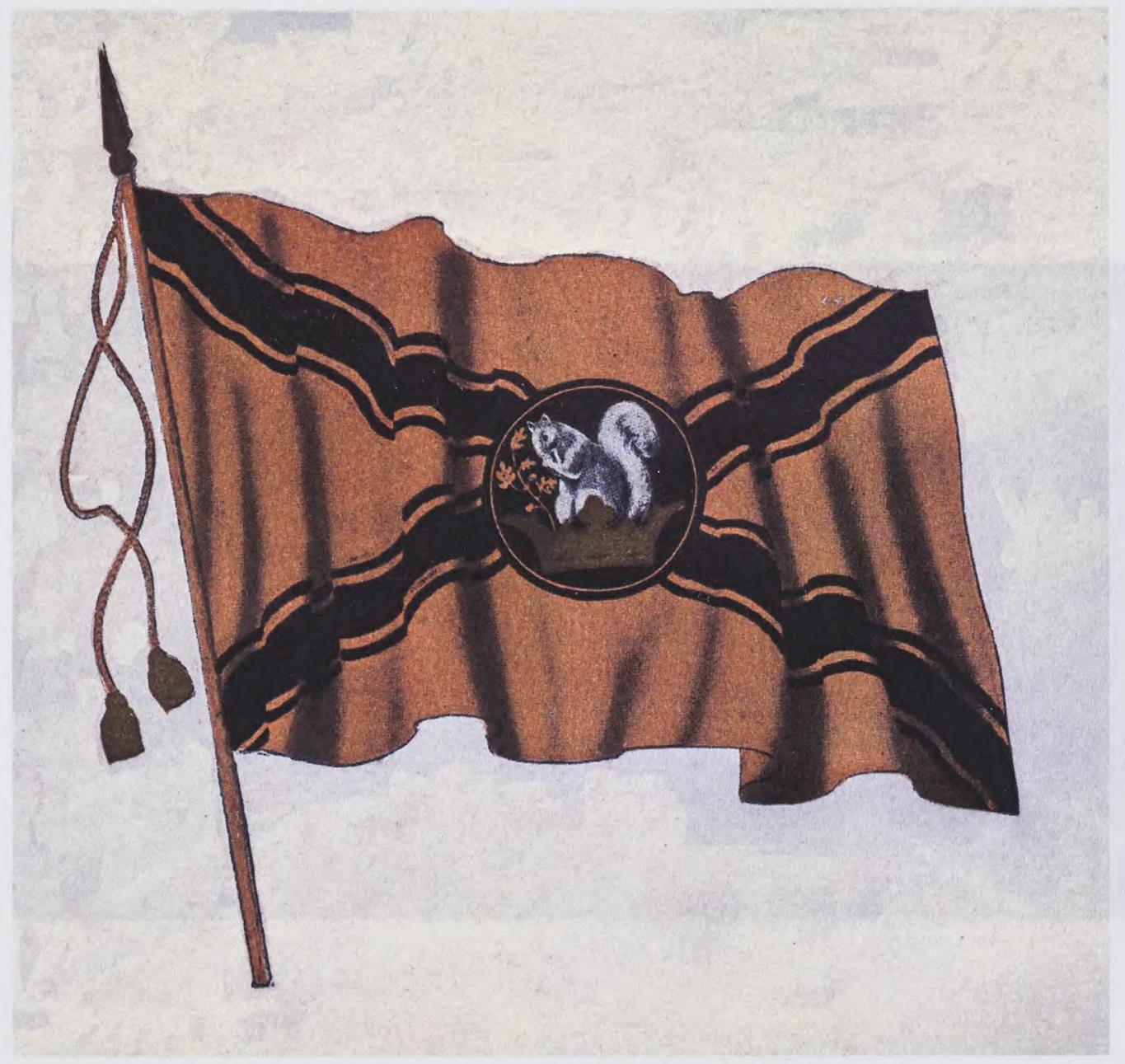

Figure 25. The Westmoreland Club flag. 


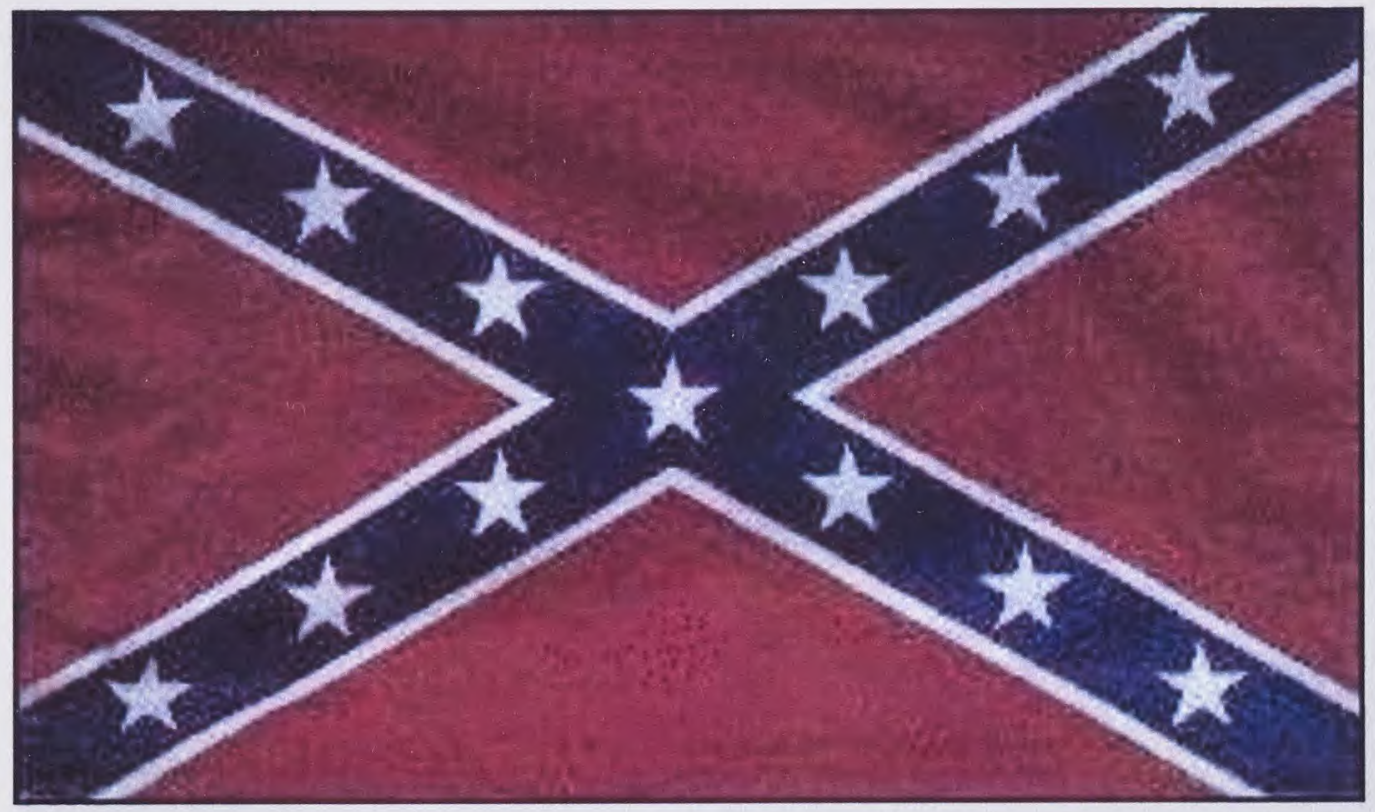

Figure 26. Flag of the Confederacy. 


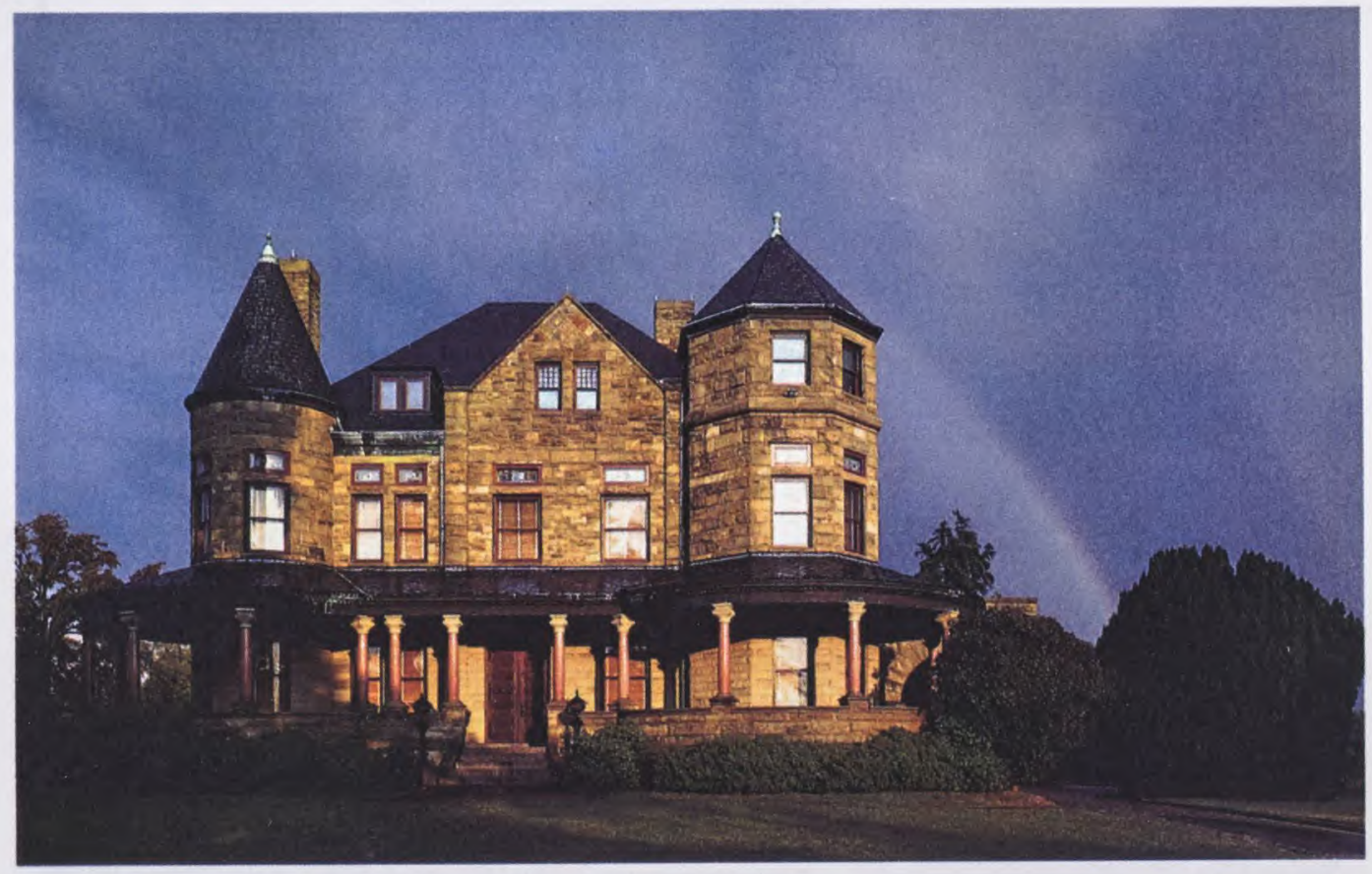

Figure 27. Maymont, Richmond, Virginia. 


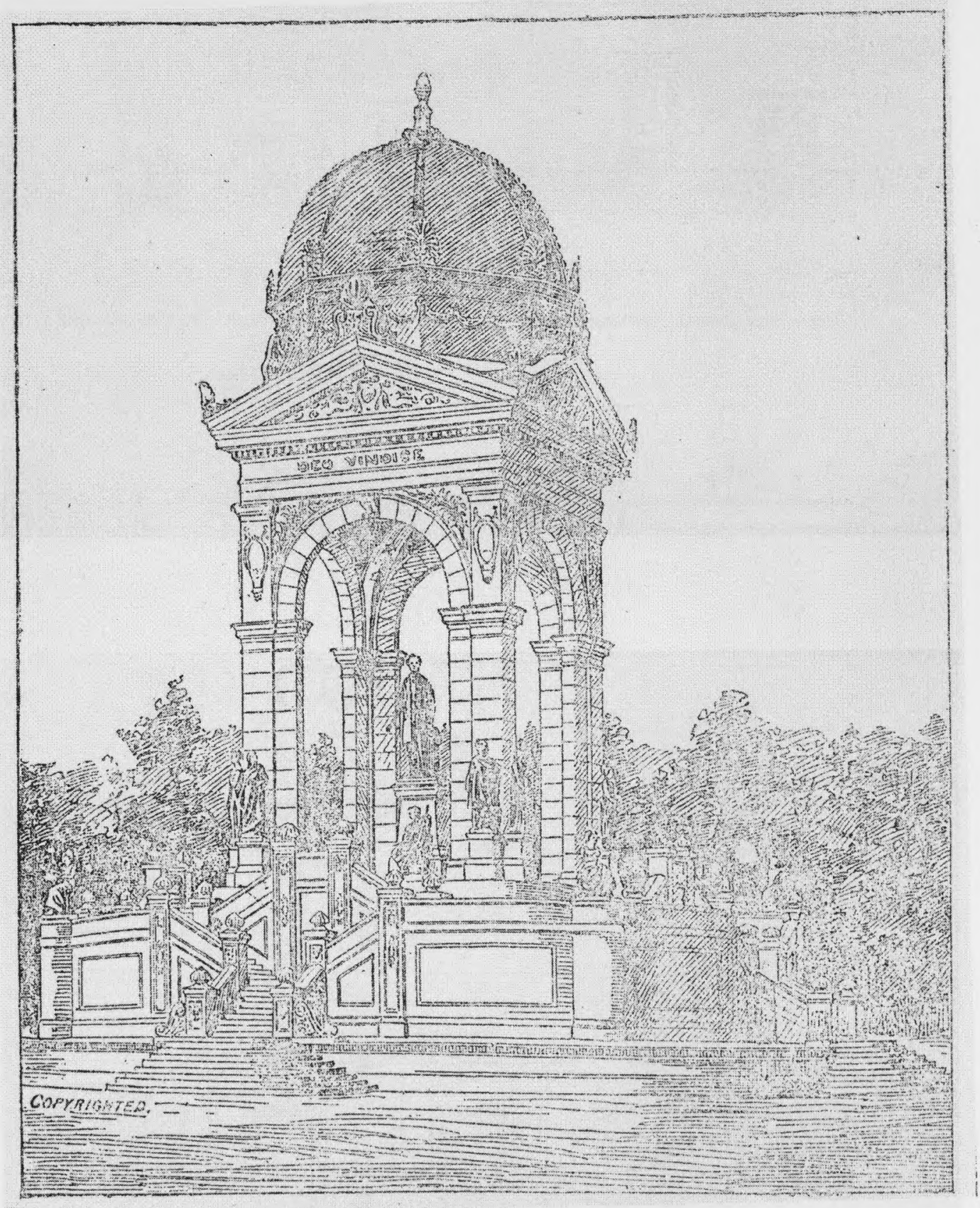

Figure 28. Edgerton Stewart Rogers's second-place design for the Jefferson Davis Monument, 1896, Richmond, Virginia. 

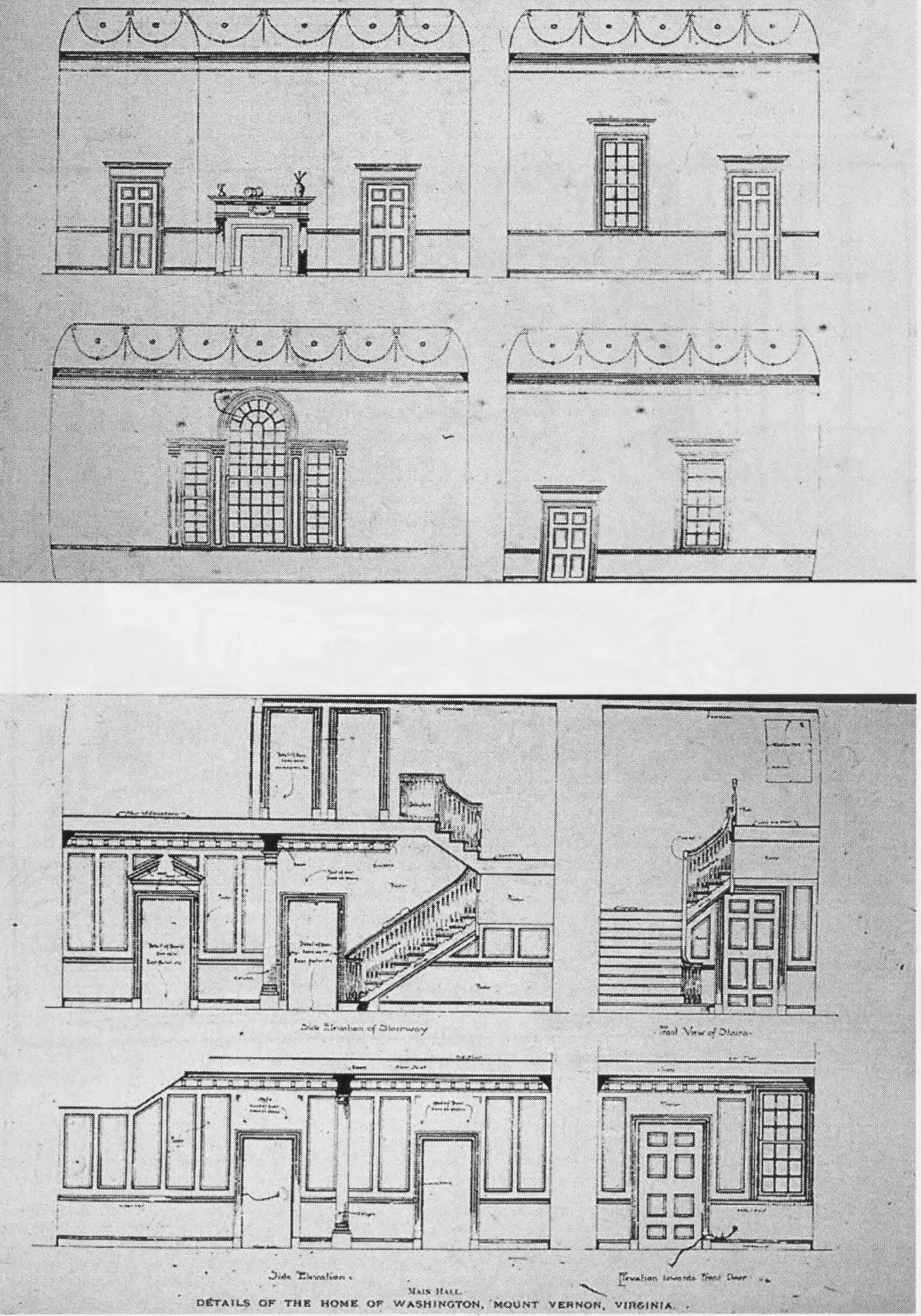

Figure 29. Edgerton Stewart Rogers's drawings for the Virginia Building. 


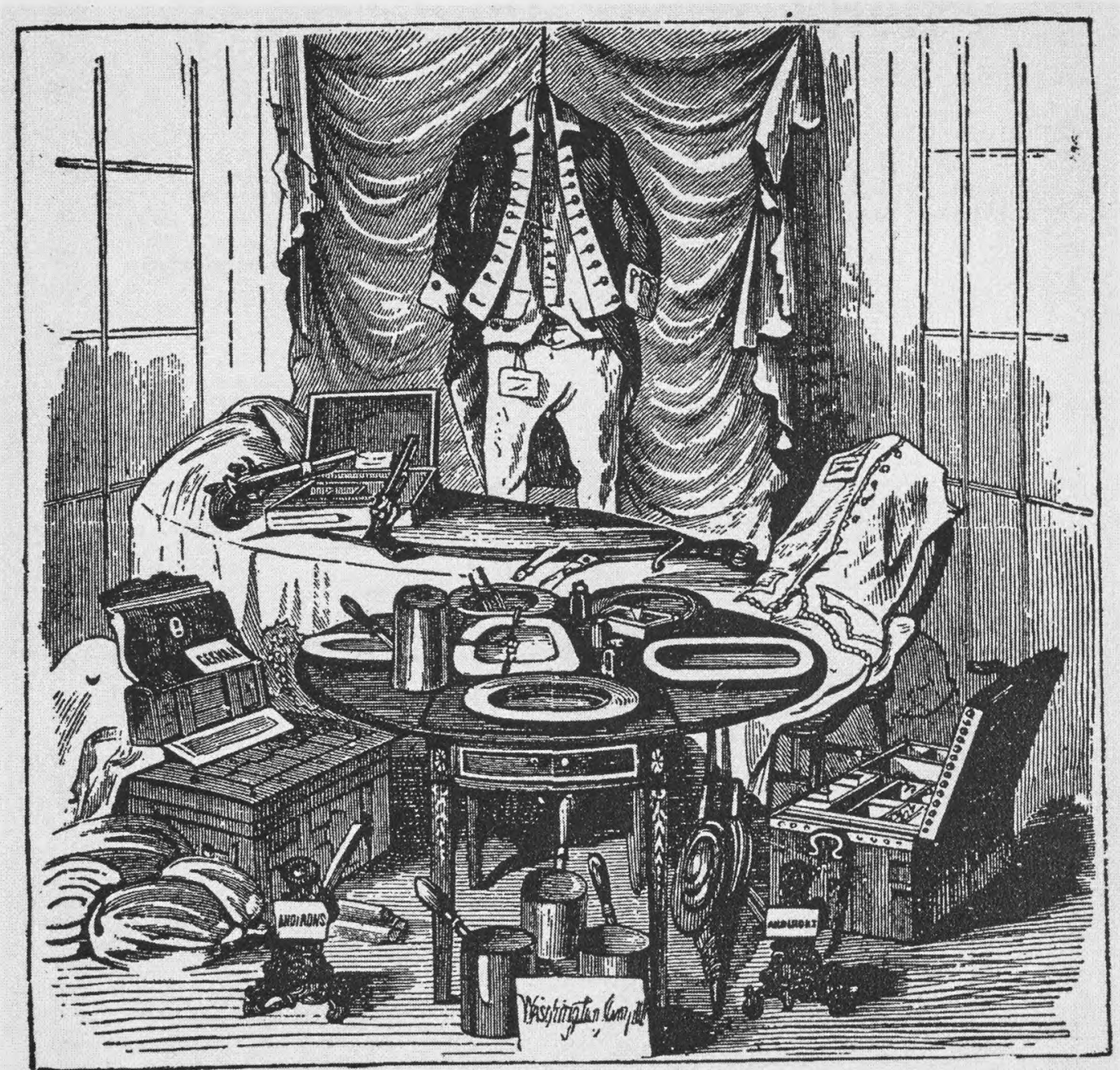

RELICS OF GEORGE WASHINGTON.

Figure 30. Relics shown in the Virginia Building. 


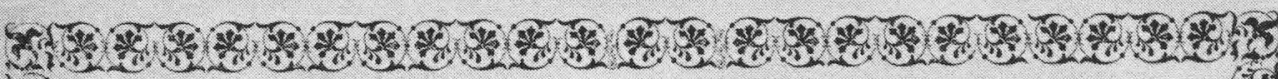
(⿶凵人)

\section{They Speak from Their Own Experience.}

Atlanta, Ga, Nov. 4, 1895

1 have used the ROYAL BAKING POWDER for years in preference to all others. It is reliable and makes the best bread for the amount used of any leavening

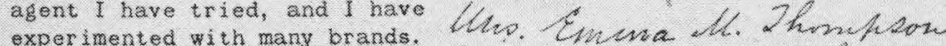

$$
\begin{aligned}
& \text { tho. Enerva th. Shomakon }
\end{aligned}
$$

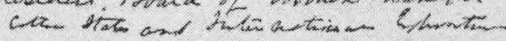

Buchanan, Va, Now, 5,4895 It gives me pleasure to featify that $f$ have used Royal
I cheerfully reconmend to all housekeegers the Royal
Baking Powder for many years and find it far superior to Baking Powder. For its excellert raising propertes and appetizing fiavor of its food it lias no superior, if an equal in the laxge list of baking powiers.

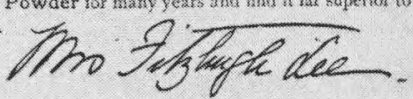

Aung Pubs Pare

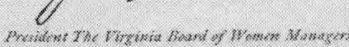

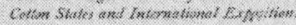

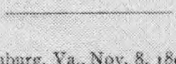

Vor a number Baking Powder uny sekecping and have found it absolutely satisfactory.
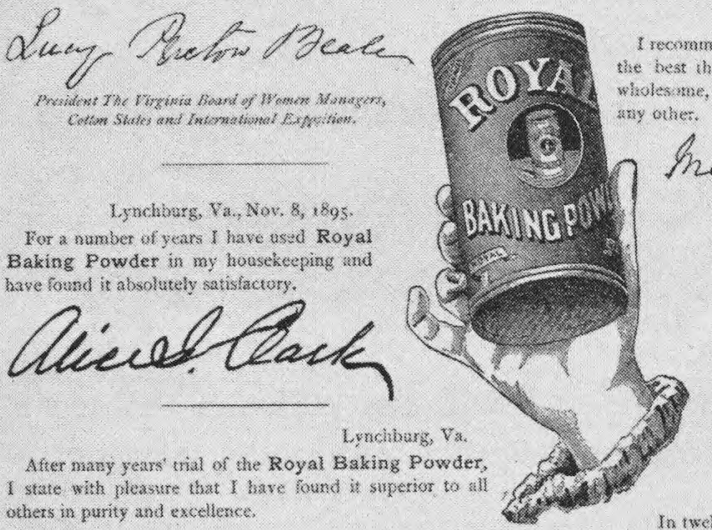

trecrmment the Royal Baking Powder as bein C best that $I$ ever used, making the lightest, most wholes mee, and the most delicions food. If never us A

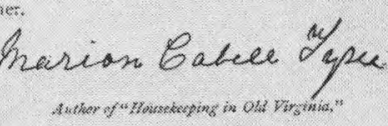

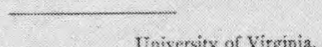

Analyses which 1 have made of the Royal aking Powder thewer that it conxains ouls the ingredienss of goot cream of tartar odinary purity, and careiully mixed and put up for use.

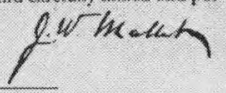
I state with pleasure that I have found it superior to in othets in purity and excellence.

$$
\text { her. GLienn }
$$

I yrefer the Royal Baking Powder for use, and can hearilly recommend it to honseheopers.

Dus hosháffey tóne Univesity of $\mathrm{V}_{2}$

1 hase used Royal Baking Powder for masy years with perfect safisfuction, and prefer it to all others. Ans fauces $M$. Sarcett.

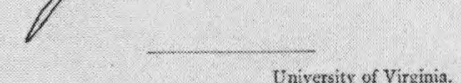

T. uxe aniy the Royat Butiag Powder, baving it the most satisfactory of all in every way.

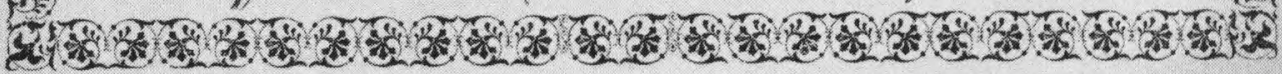

Figure 31. Royal Baking Powder Advertisement with the testimony of Lucy Preston Beale. 
Buchanan, Va., Nov. 5, 1895 .

I cheerfully recommend to all housekeepers the Royal Baking Powder. For its excellent raising properties and appetizing flavor of its food it has no superior, if an equal, in the large list of baking powders.

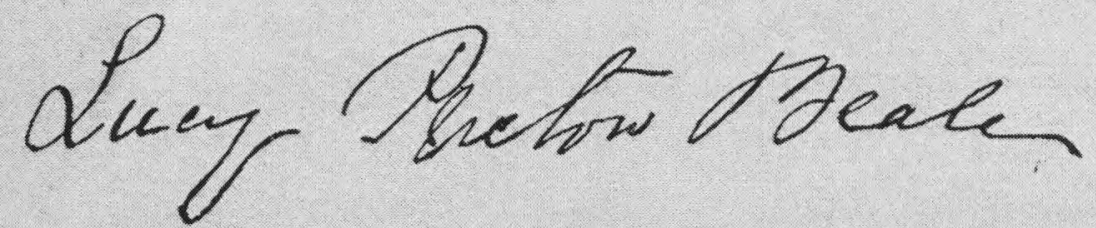

President The Virginia Board of Women Managers, Cotton States and International Exposition. 


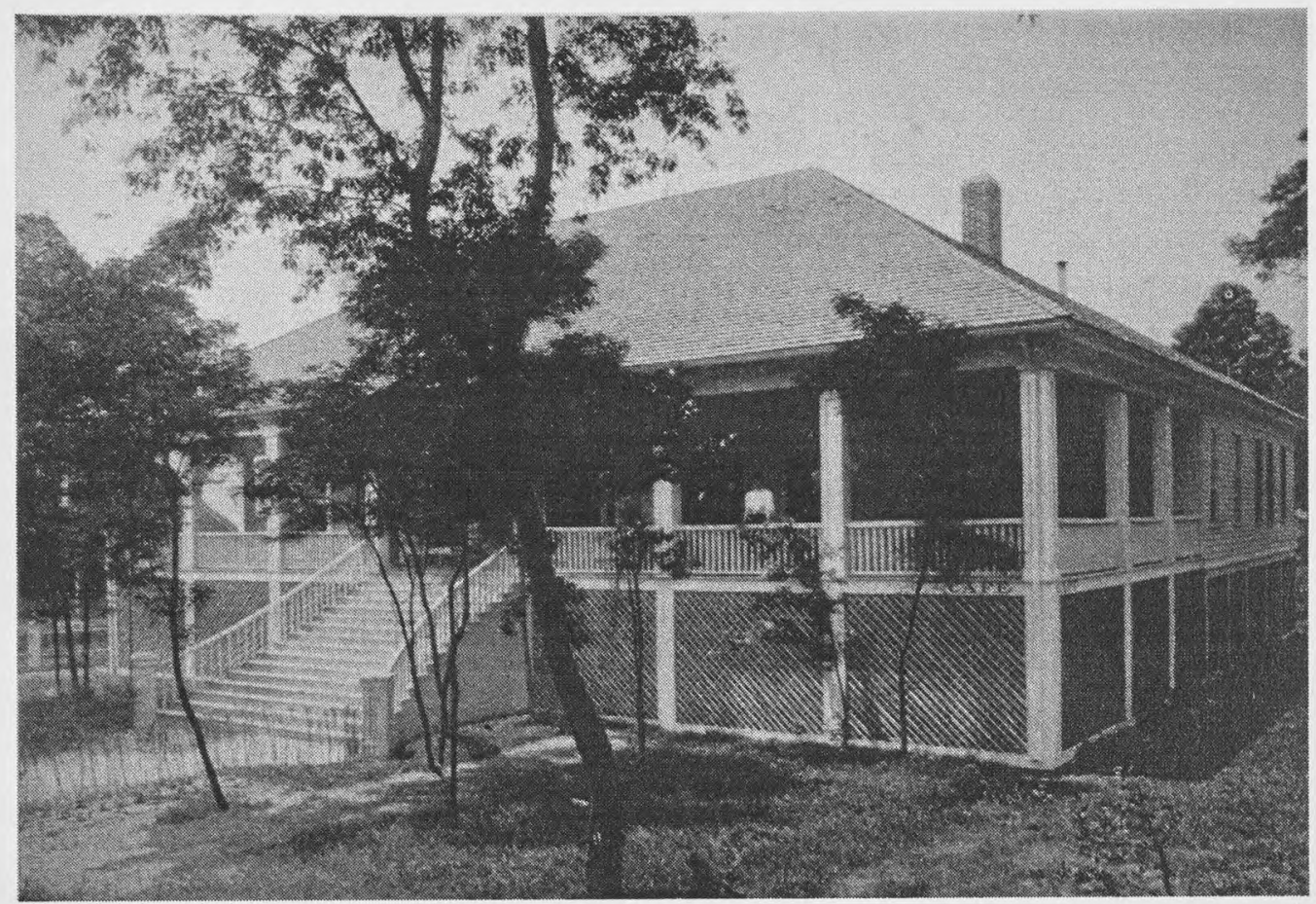

Figure 33. The United Daughters of the Confederacy Building at the 1907 Jamestown Tercentennial Exposition, a copy of Jefferson Davis's Mississippi home of Beauvoir. 


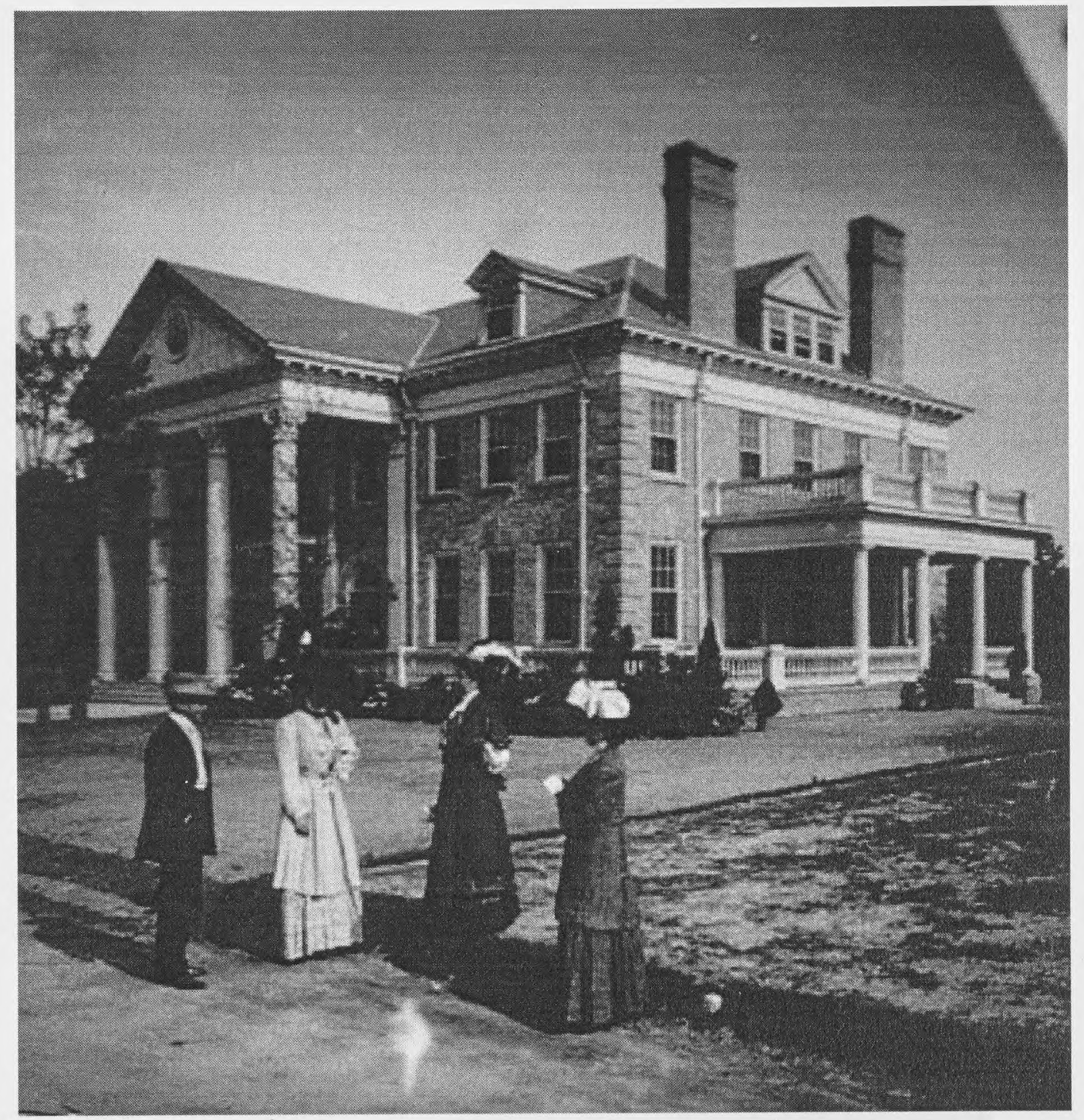

Figure 34. The Virginia Building at the 1907 Jamestown Exposition. 


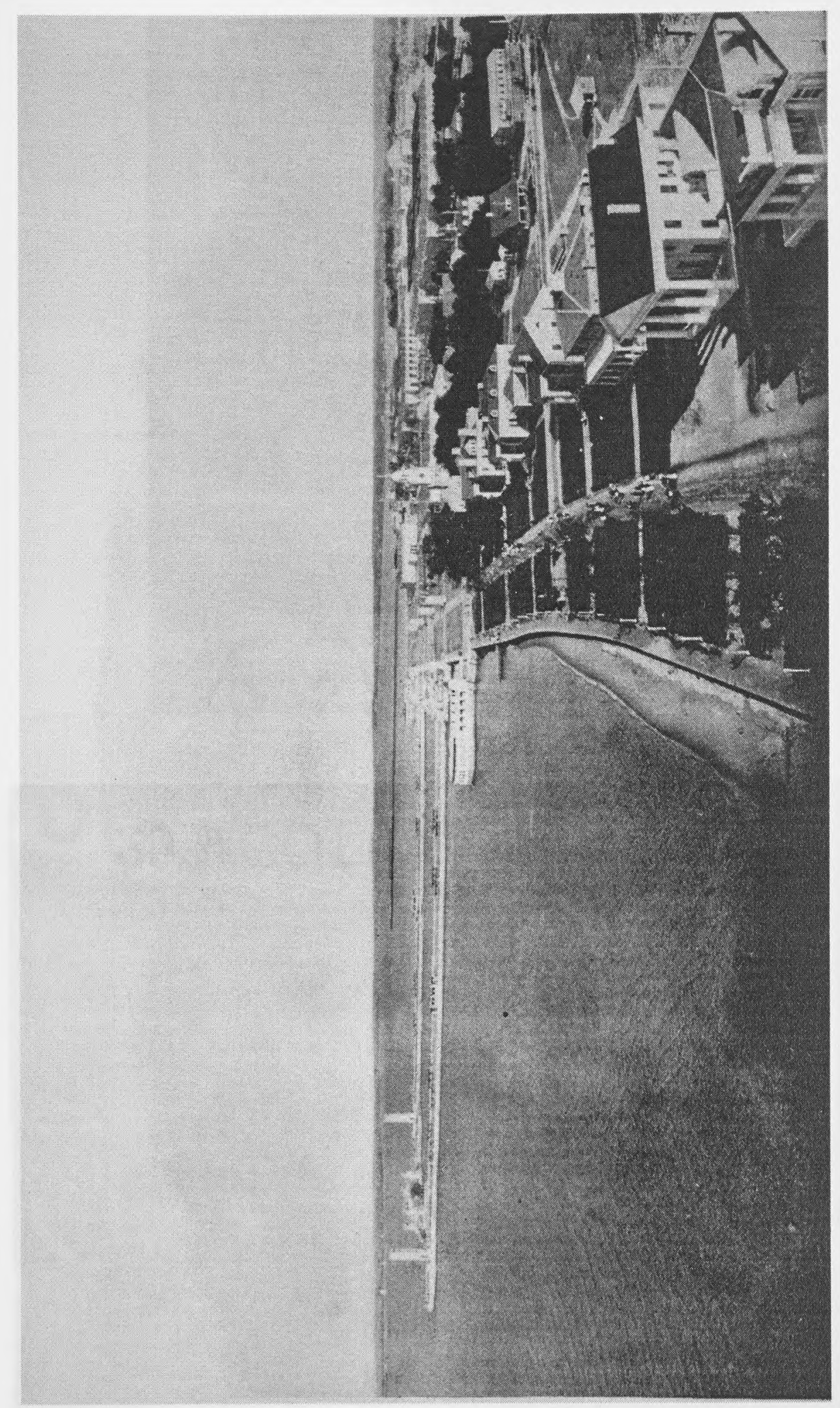

Figure 35. State Buildings at the 1907 Jamestown Exposition. 

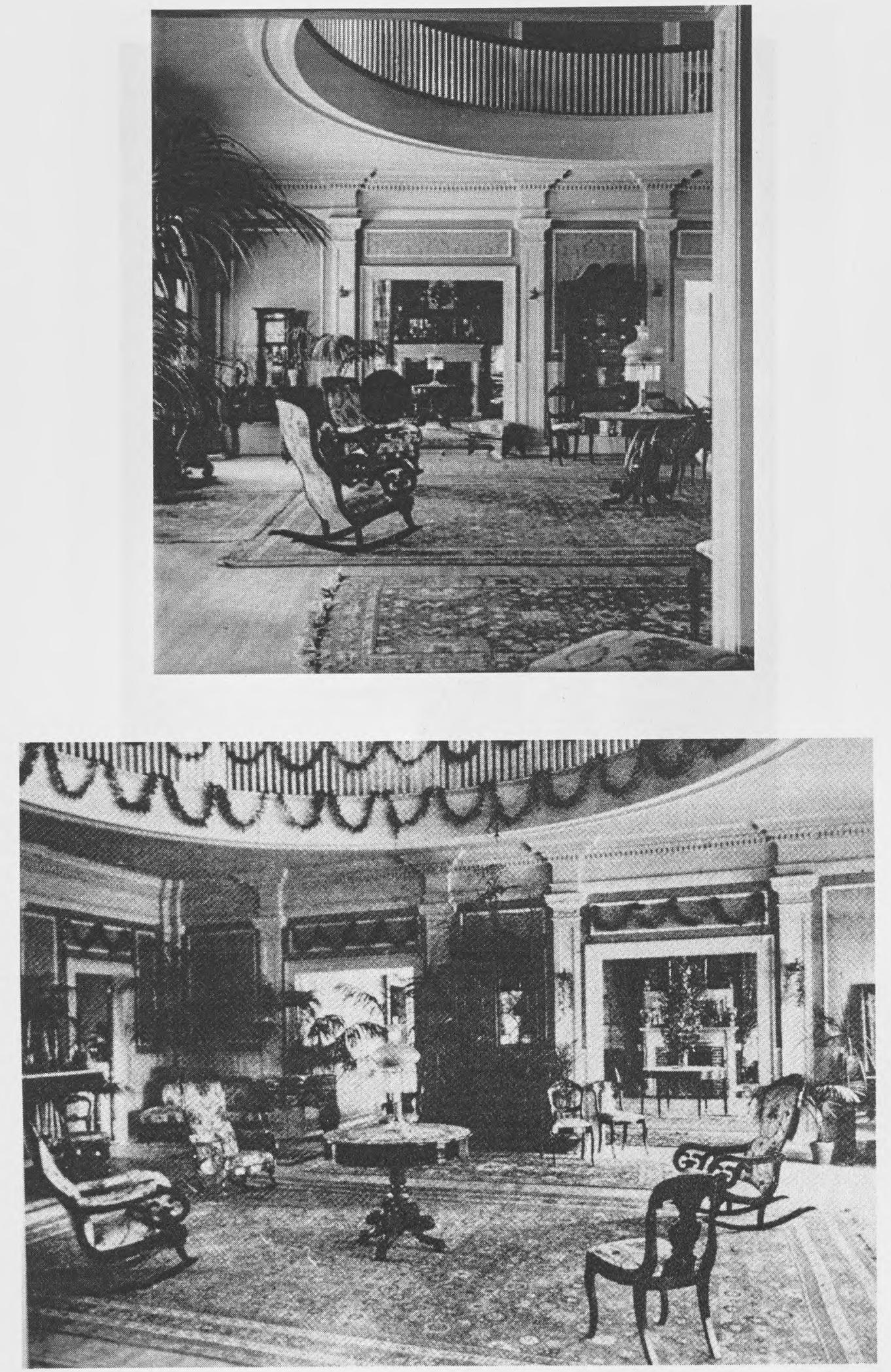

Figures 36 and 37. Interior of the Virginia Building. 


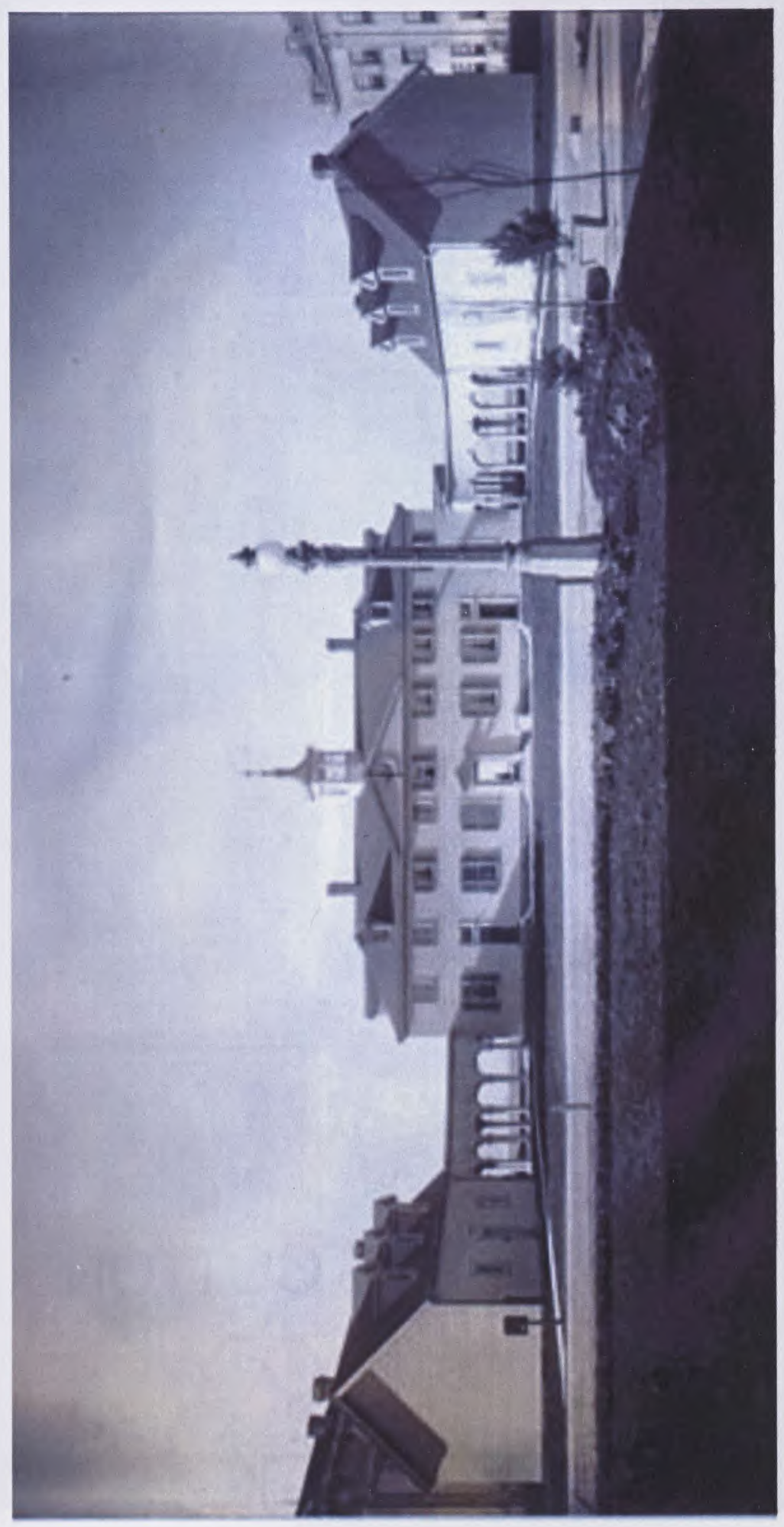

Figure 38. Virginia Building at the 1915 Panama-Pacific International Exposition in San Francisco, California. 


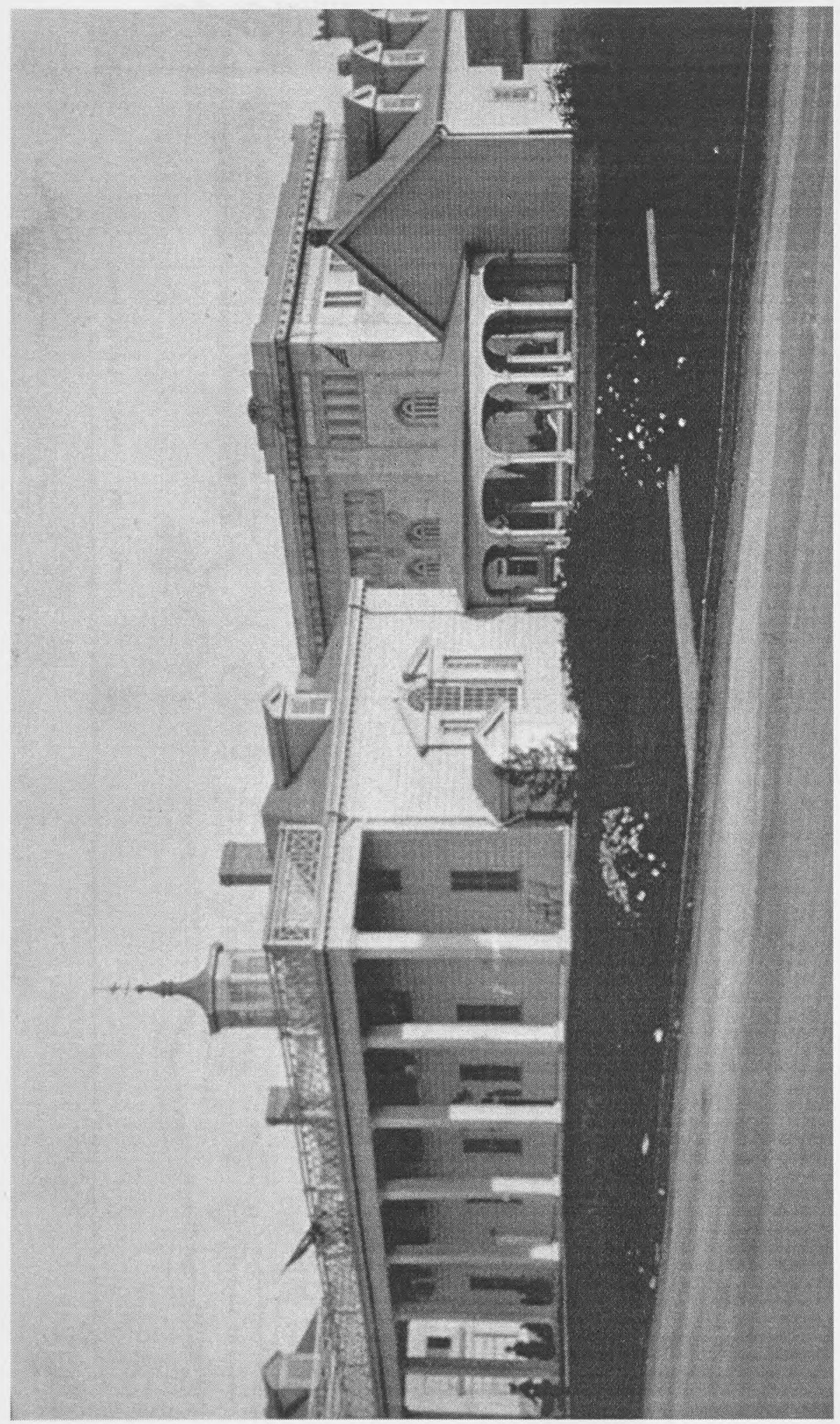

Figure 39. The 1915 Virginia Building. 


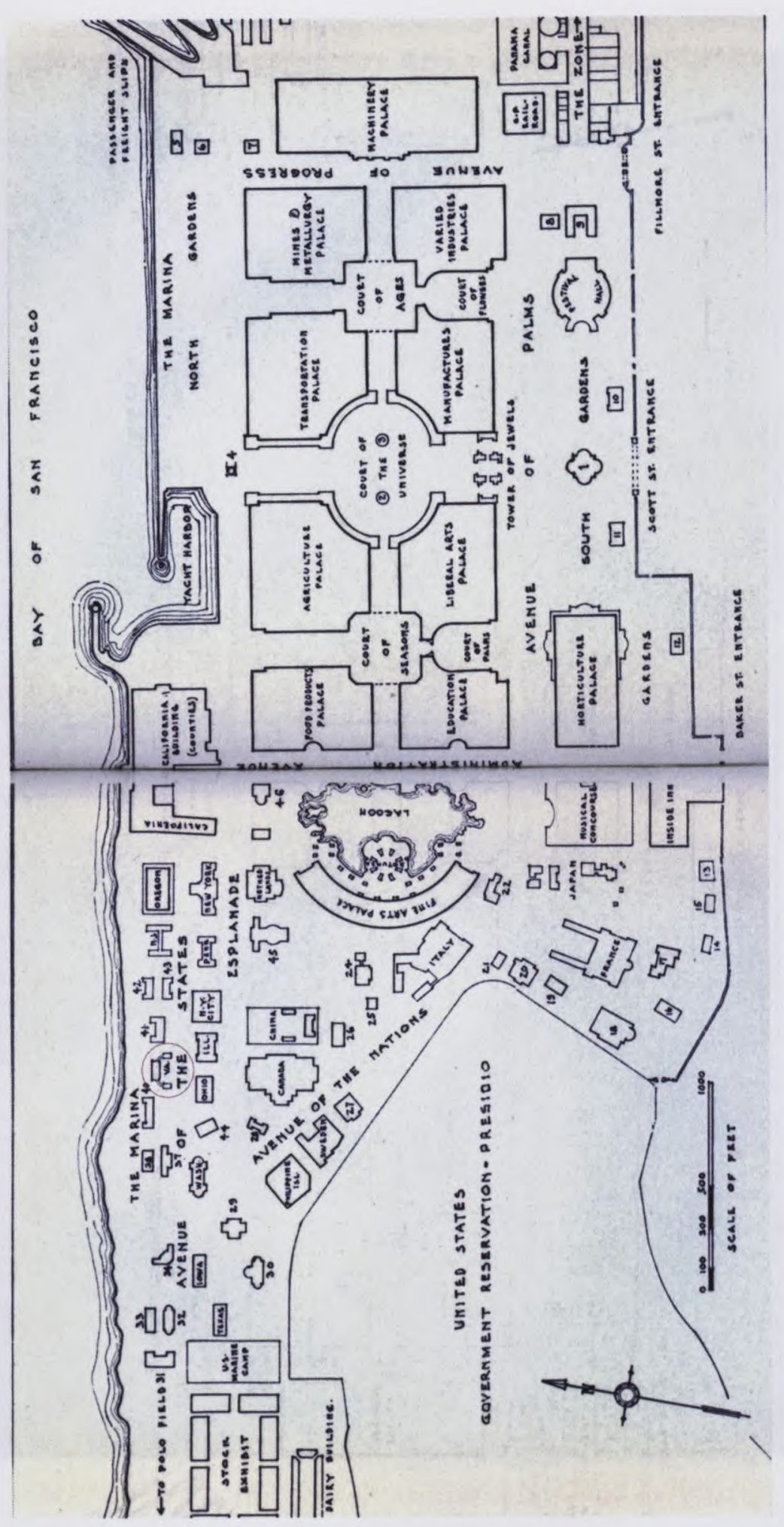

Figure 40. Map of the 1915 Panama-Pacific Exposition, the red circle indicating the location of the Virginia Building. 


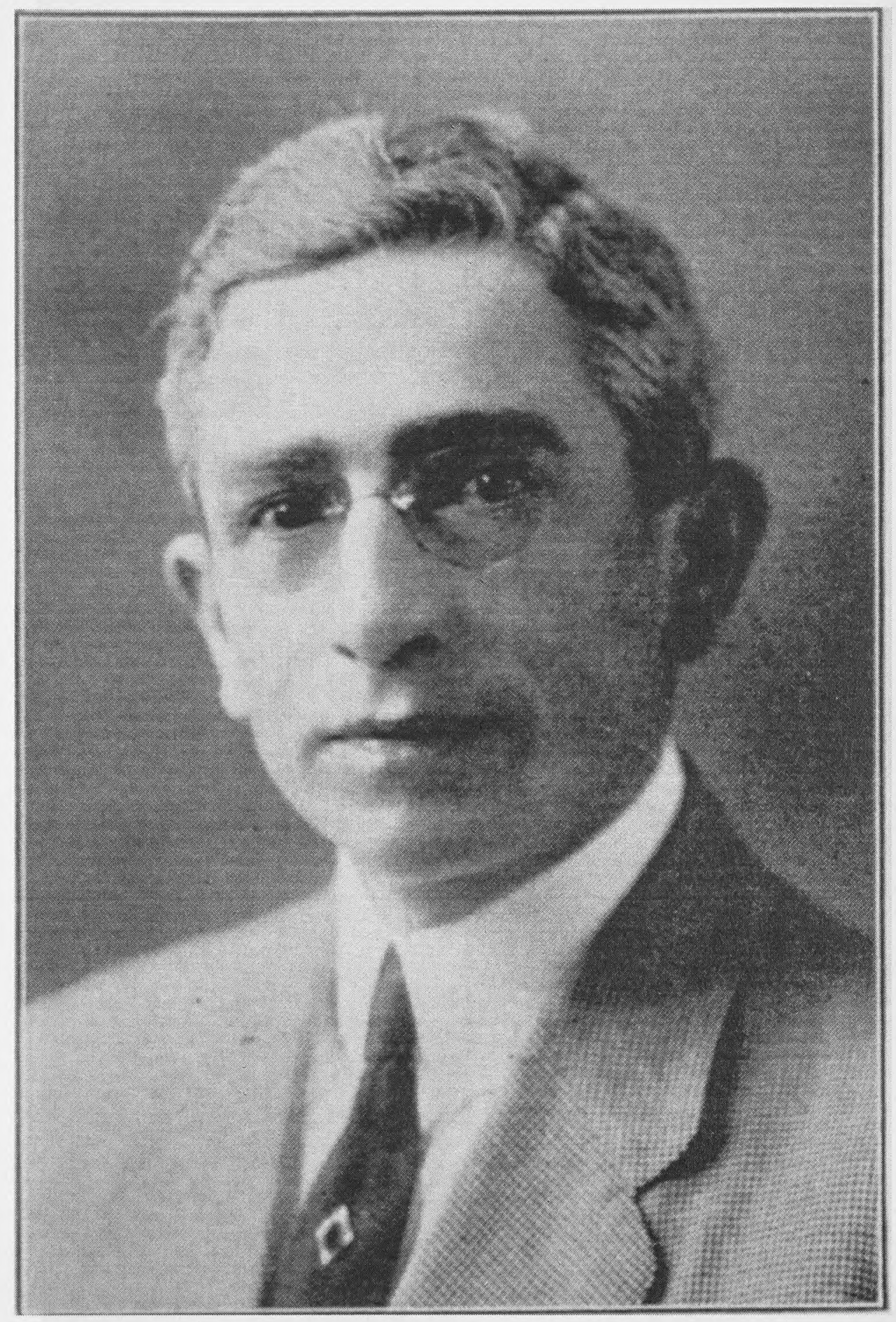

Figure 41. Charles K. Bryant. 


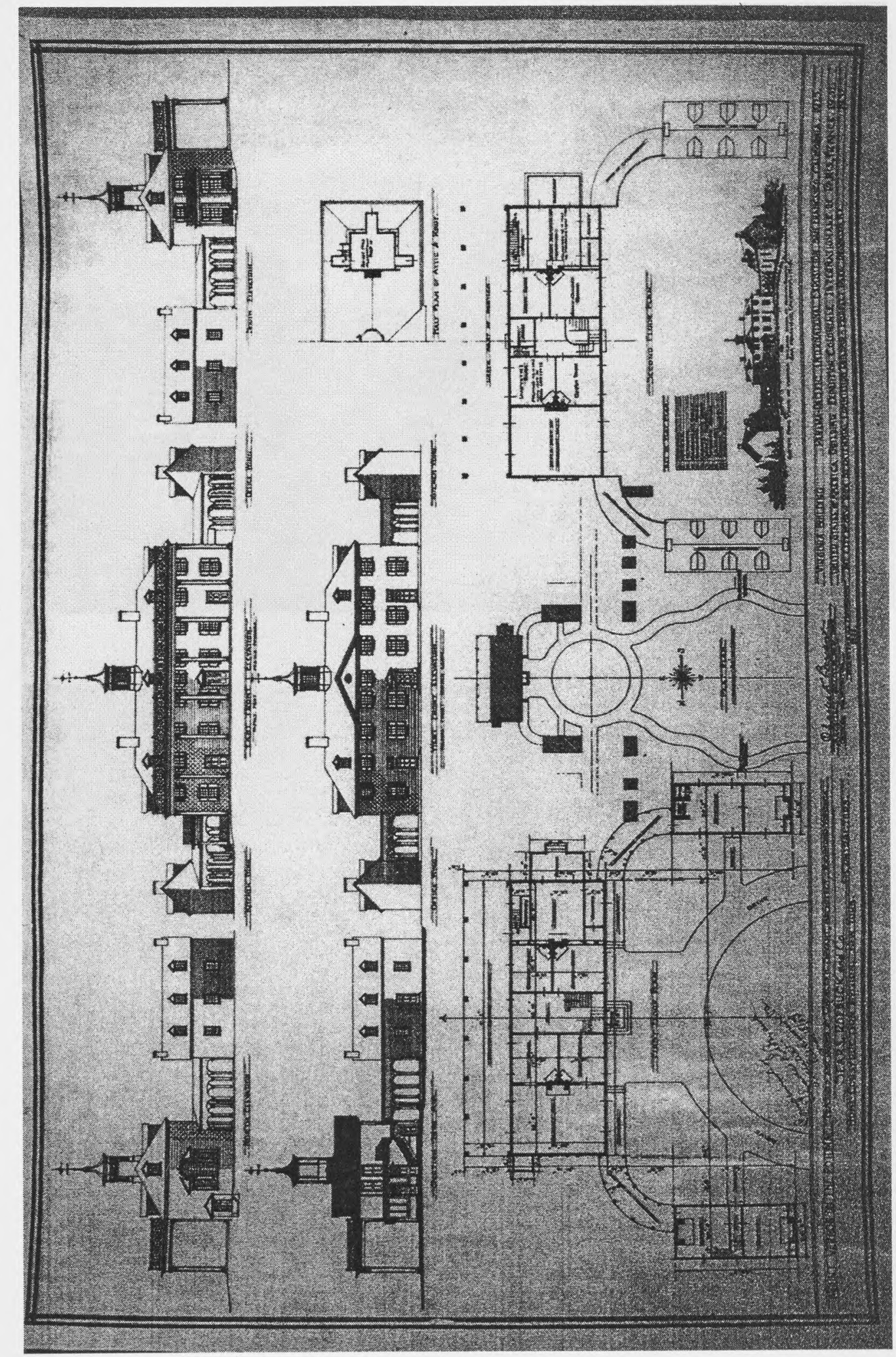

Figure 42. Charles K. Bryant's drawings of Mount Vernon for the 1915 Virginia Building. 

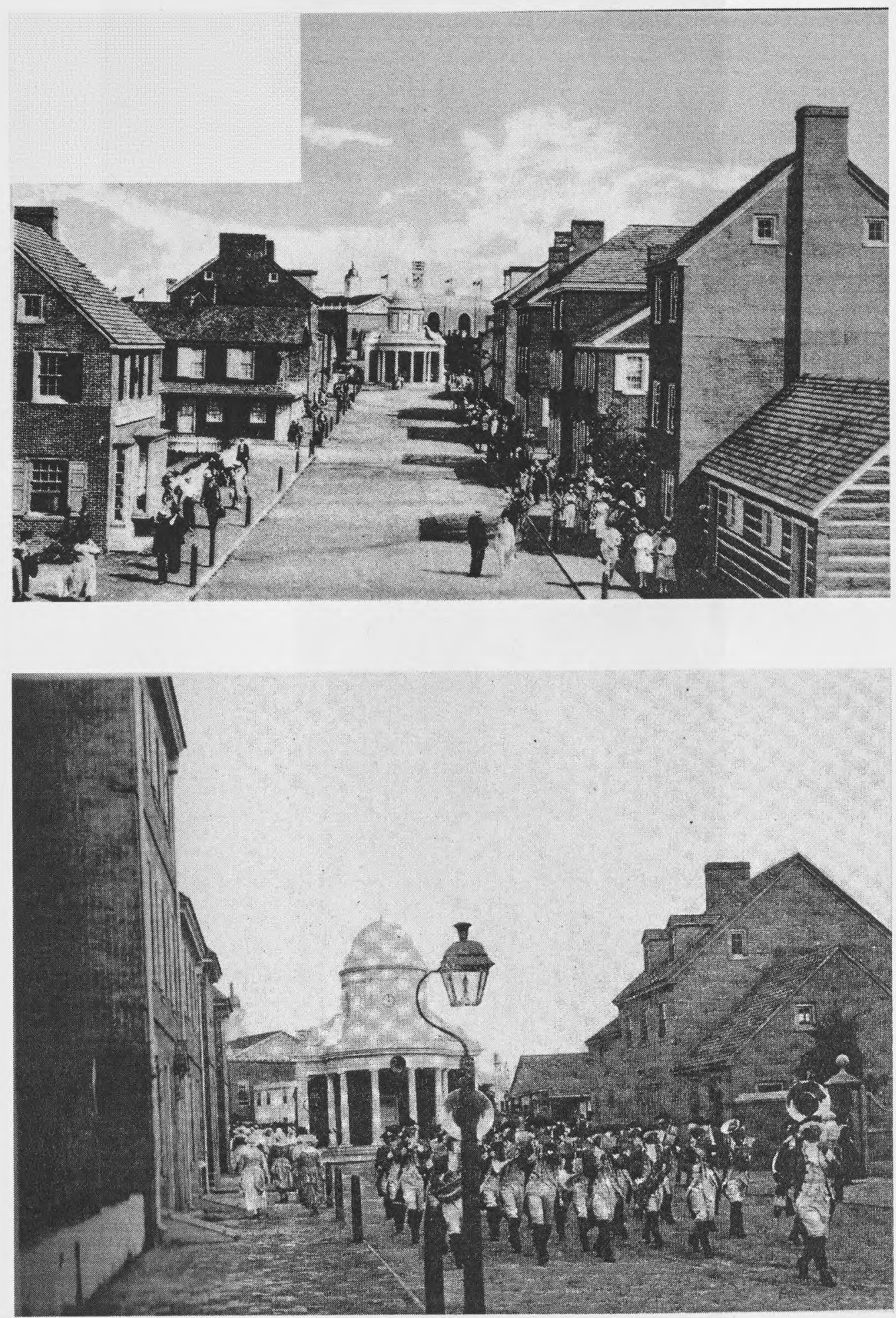

Figures 43 and 44. High Street at the 1926 Philadelphia Sesqui-Centennial. 


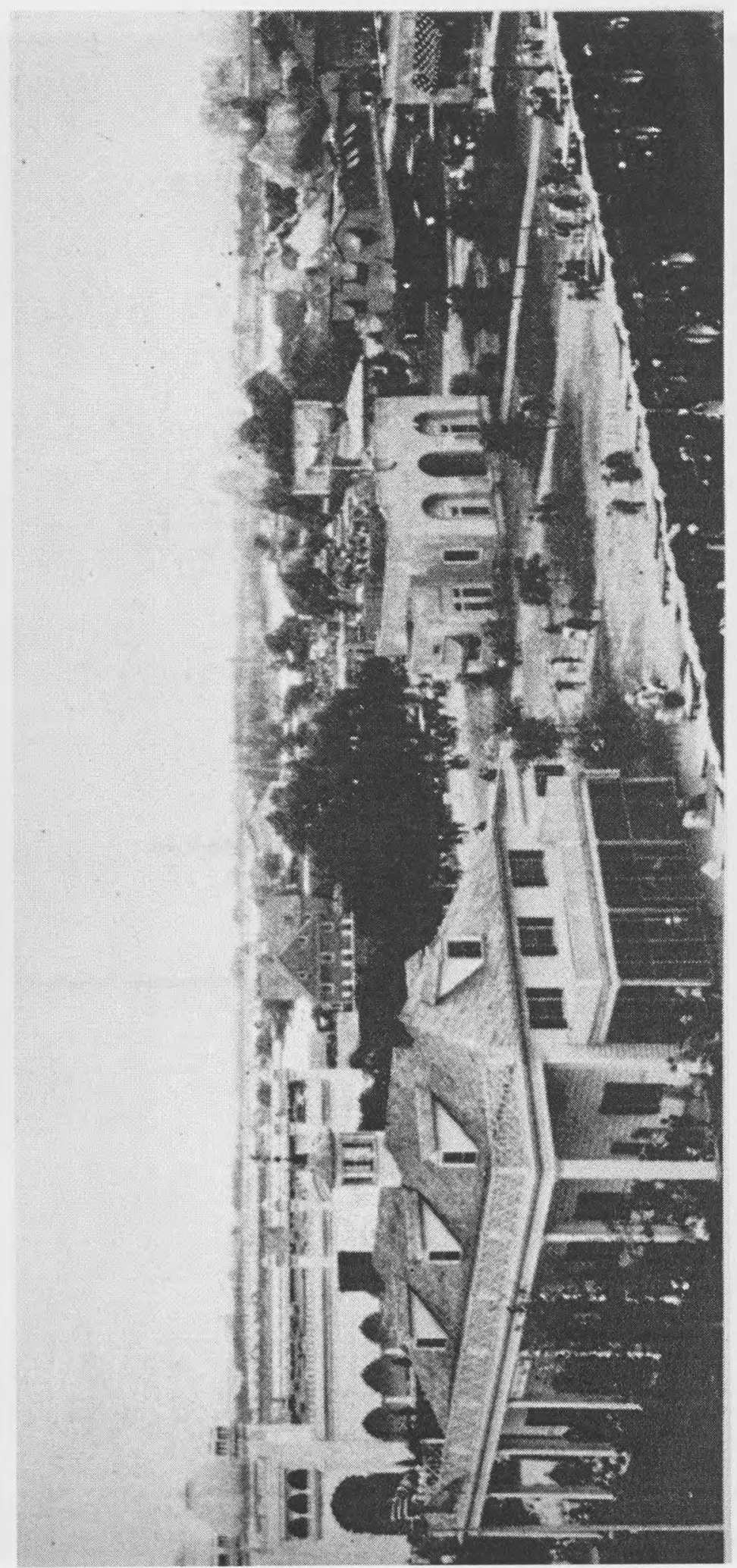

Figure 45. Young Women's Christian Association cafeteria at the 1926 Sesqui-Centennial in Philadelphia. 


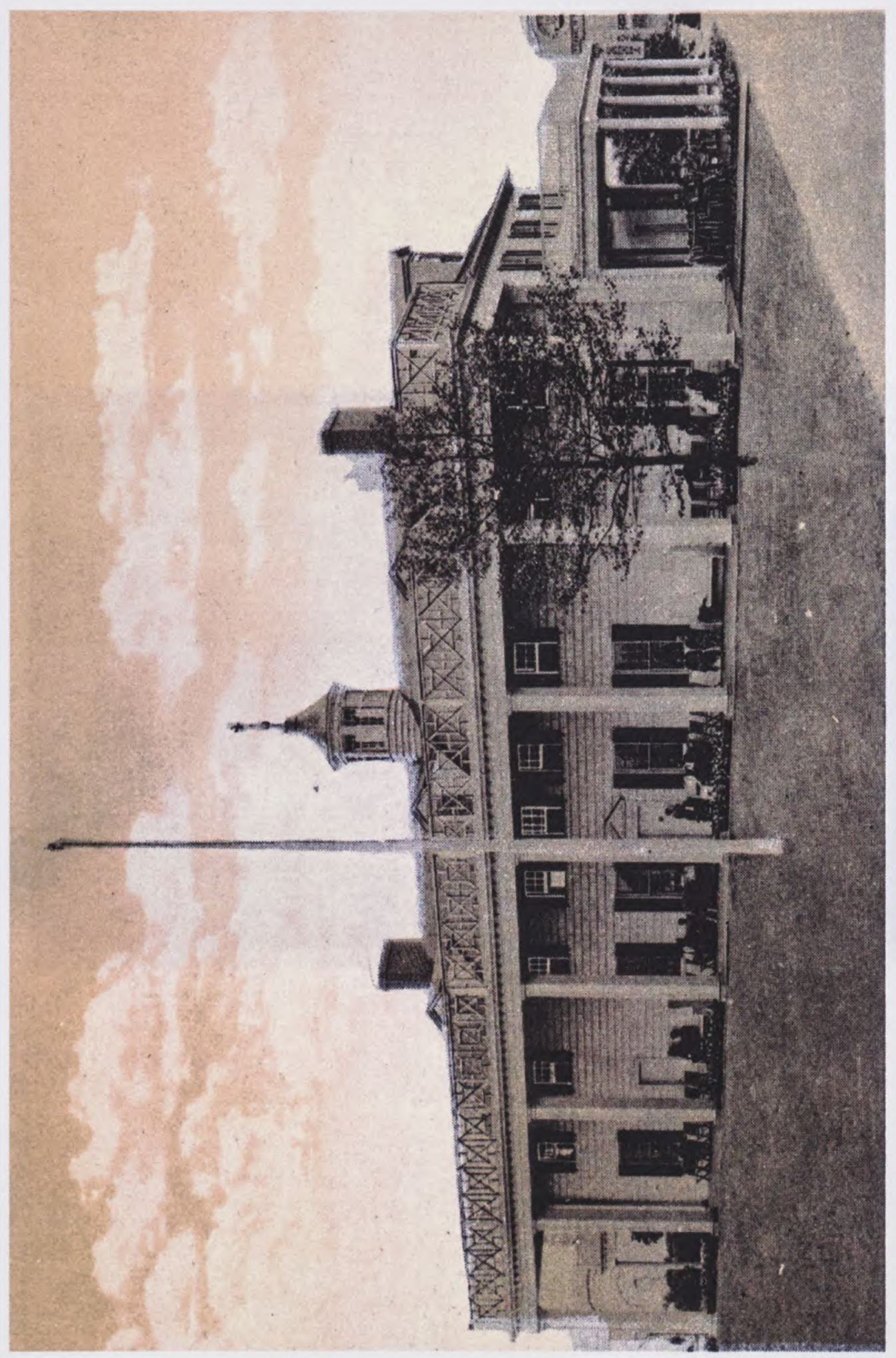

Figure 46. The YWCA cafeteria. 


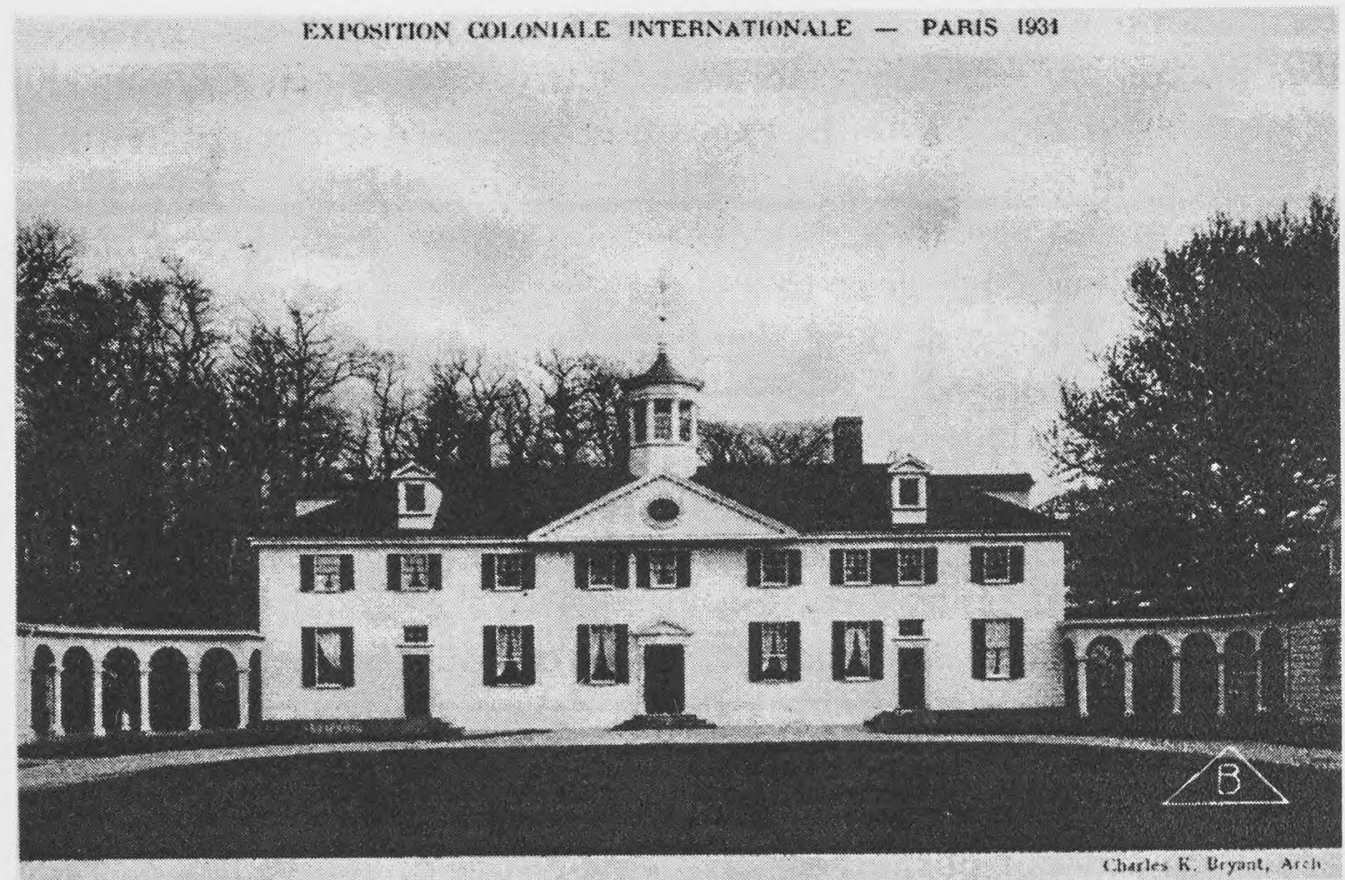

Figure 47. The United States Building at the 1931 Paris International and Colonial Overseas Exposition, designed by Charles K. Bryant and contracted by Sears, Roebuck and Company. 


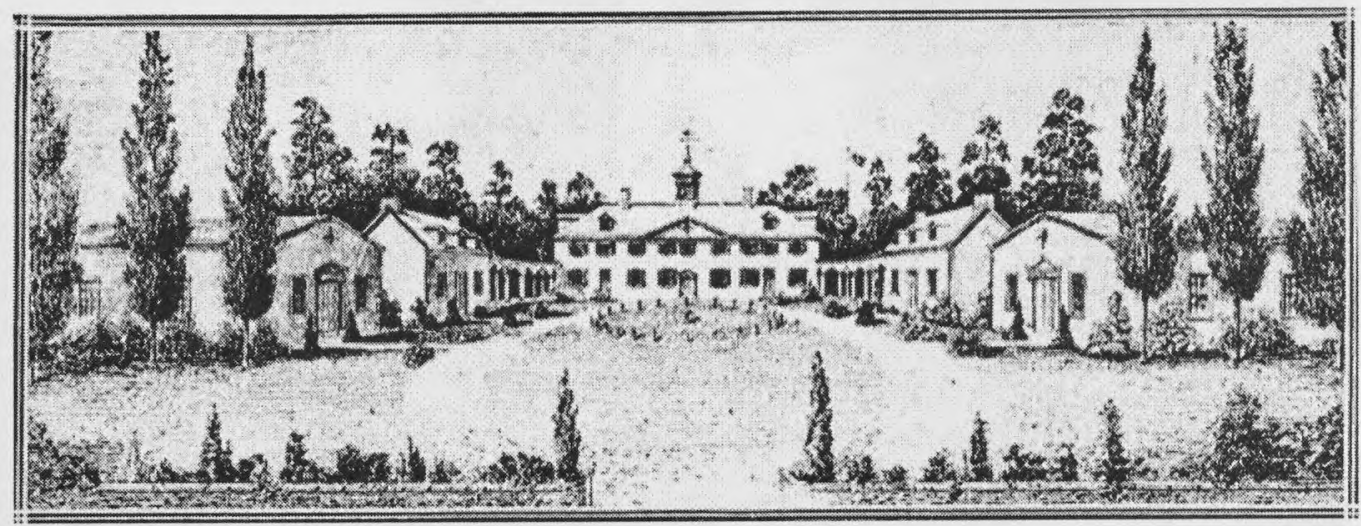

Figure 48. Bryant's rendering of the United States complex at the 1931 Paris Exposition. 


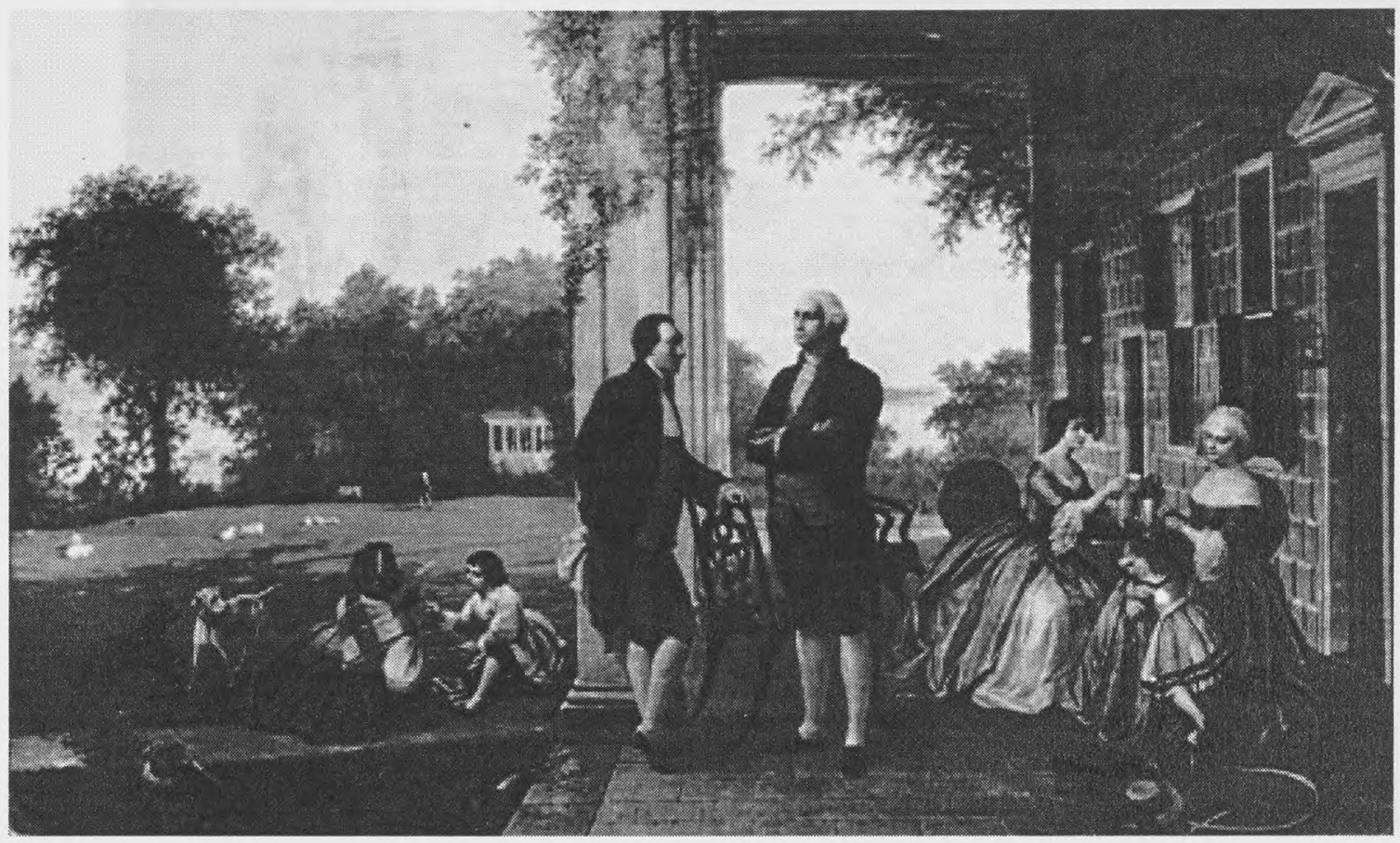

Figure 49. Thomas Pritchard Rossiter and Louis Remy Mignot, "Washington and Lafayette at 1859 at Mount Vernon, 1784 (The Home of Washington after the War)," 1859 , oil on canvas. 


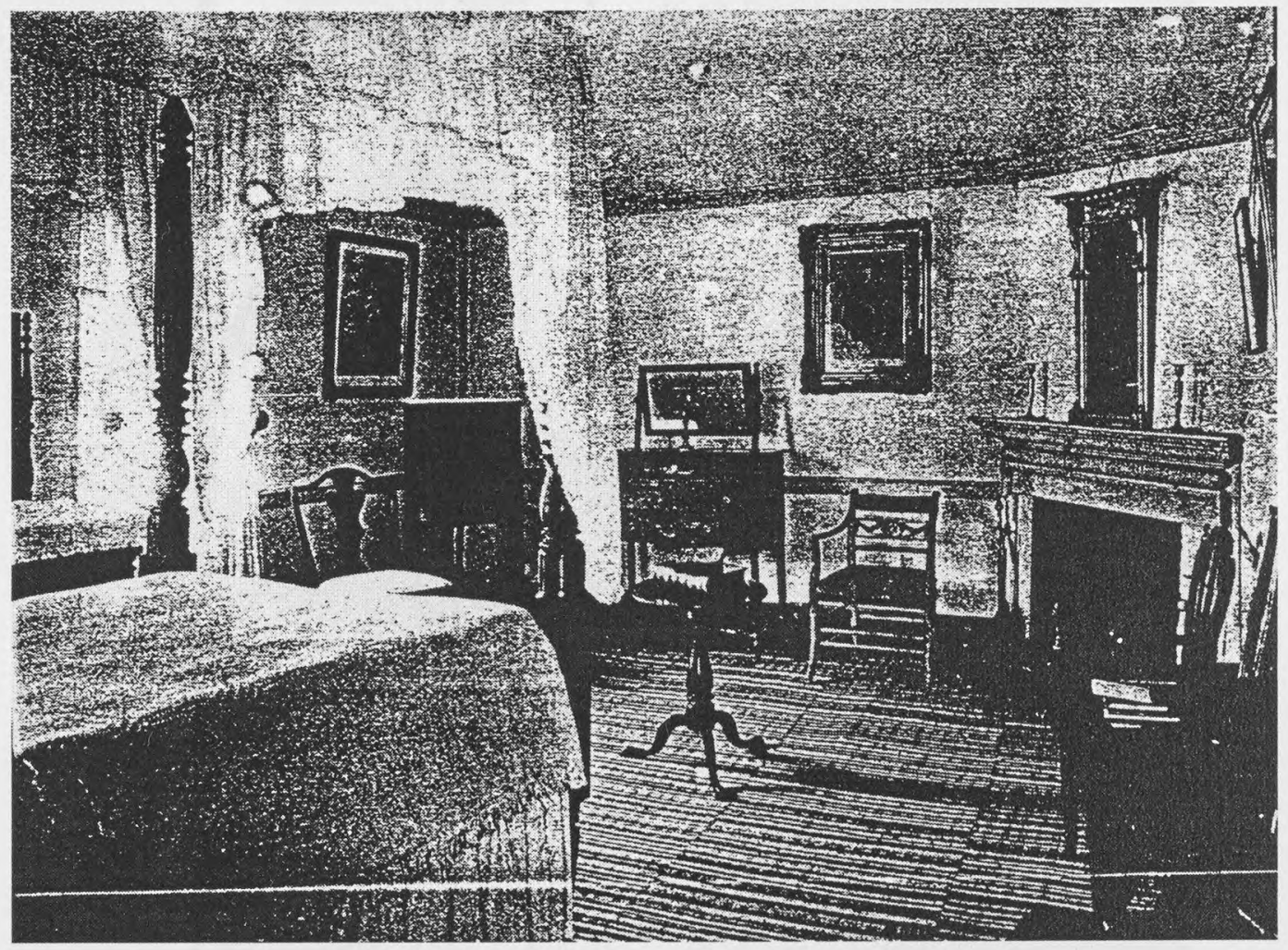

Figure 50. Lafayette's bedroom as reproduced in the 1931 United States Building. 


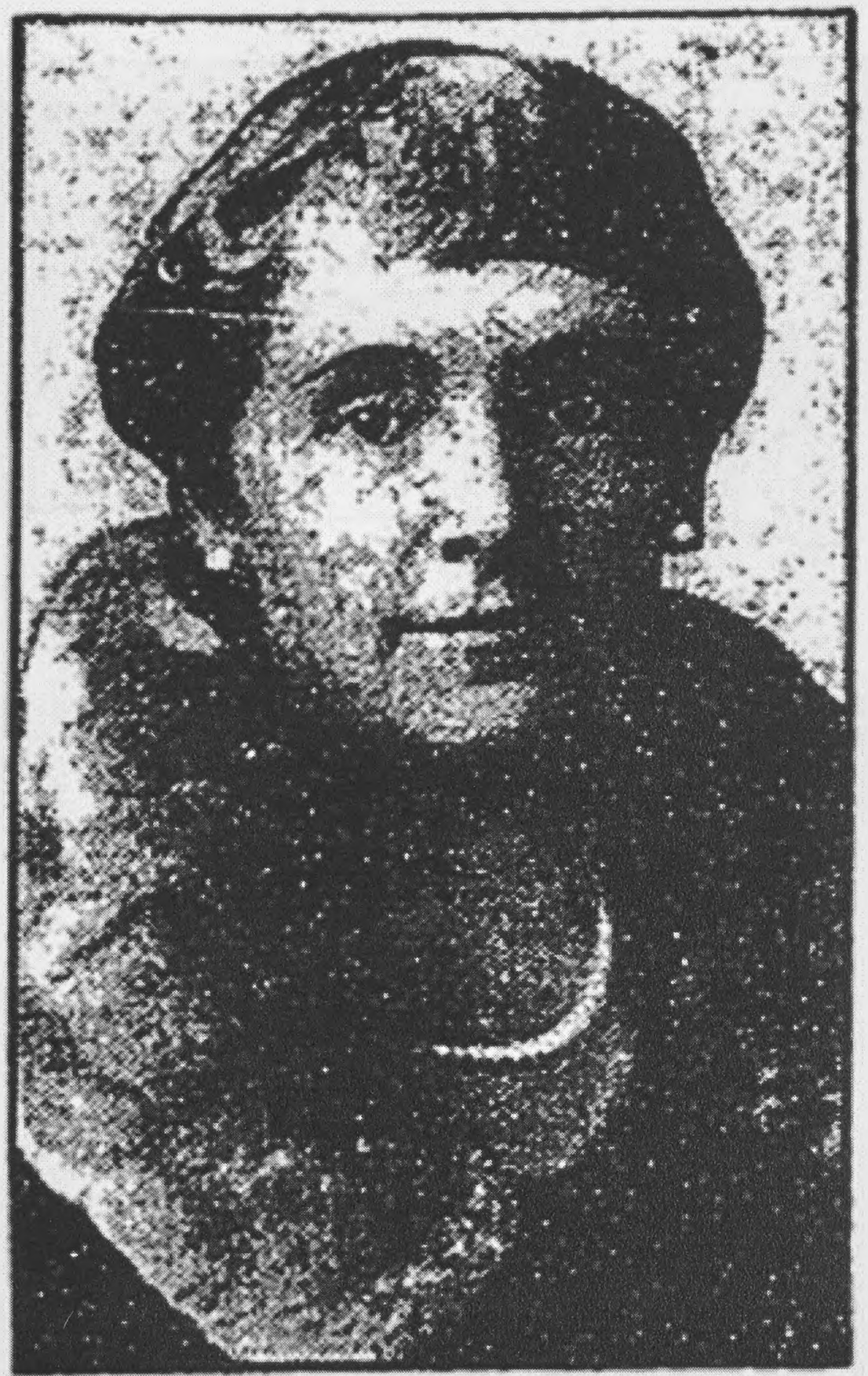

Figure 51. Anne Madison Washington. 


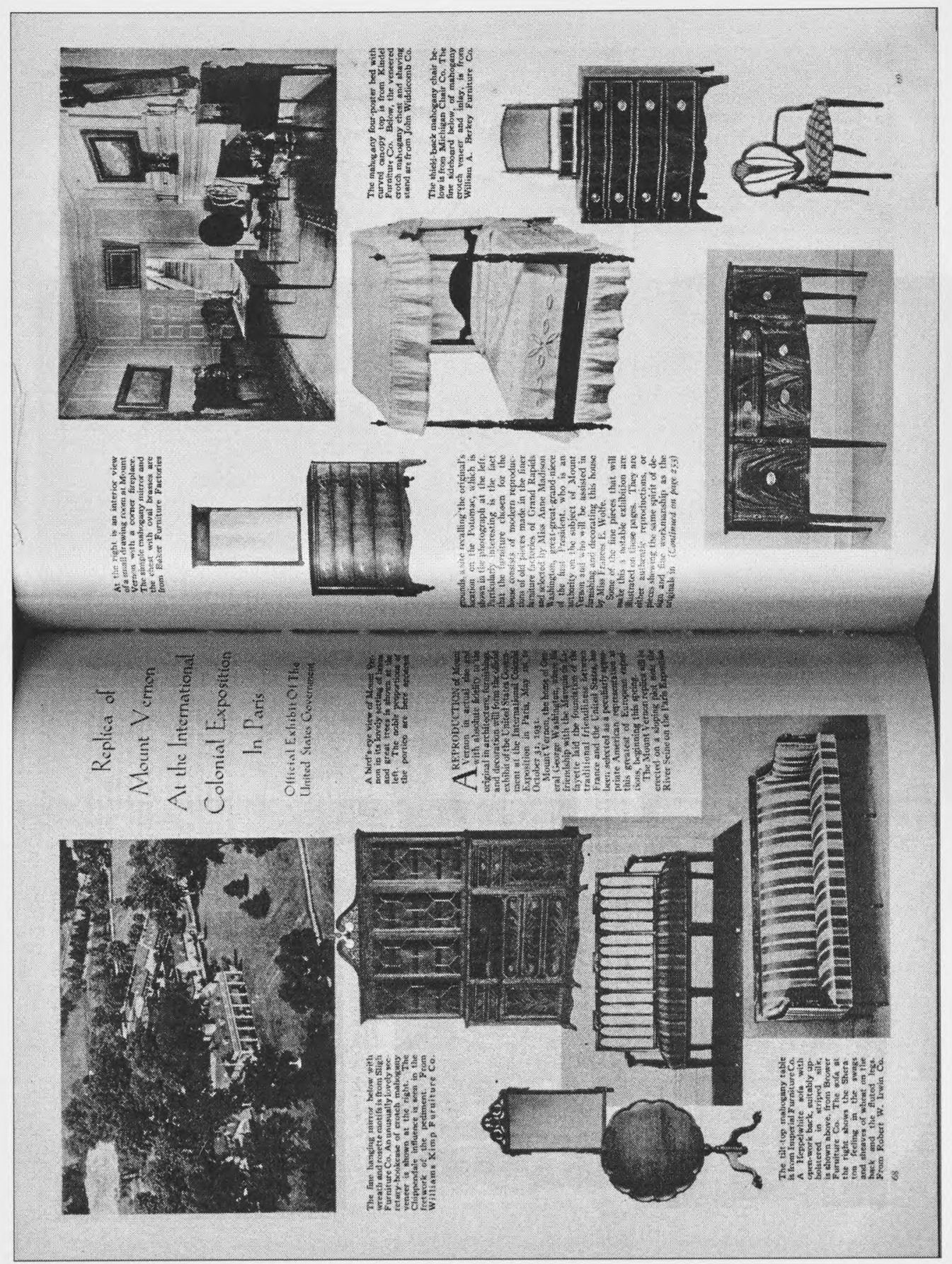

Figure 52. Good Housekeeping's coverage of the 1931 Paris Exposition building with emphasis on the manufacturers of the reproduction furniture. 


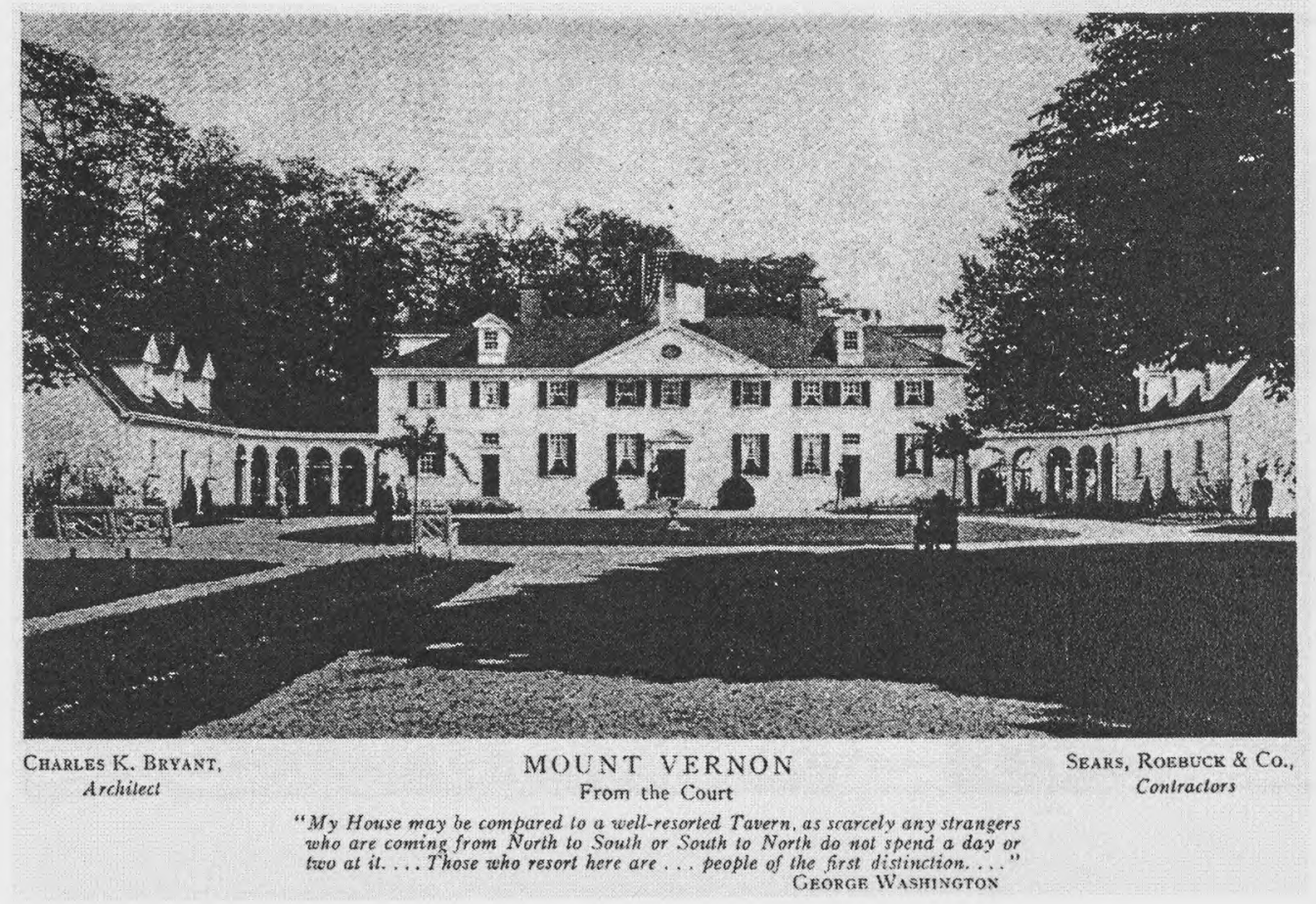

Figure 53. Mount Vernon replica erected in Prospect Park, Brooklyn, for the 1932 New York City Bicentennial celebration of Washington's birthday, designed by Charles K. Bryant and built by Sears, Roebuck and Company. 


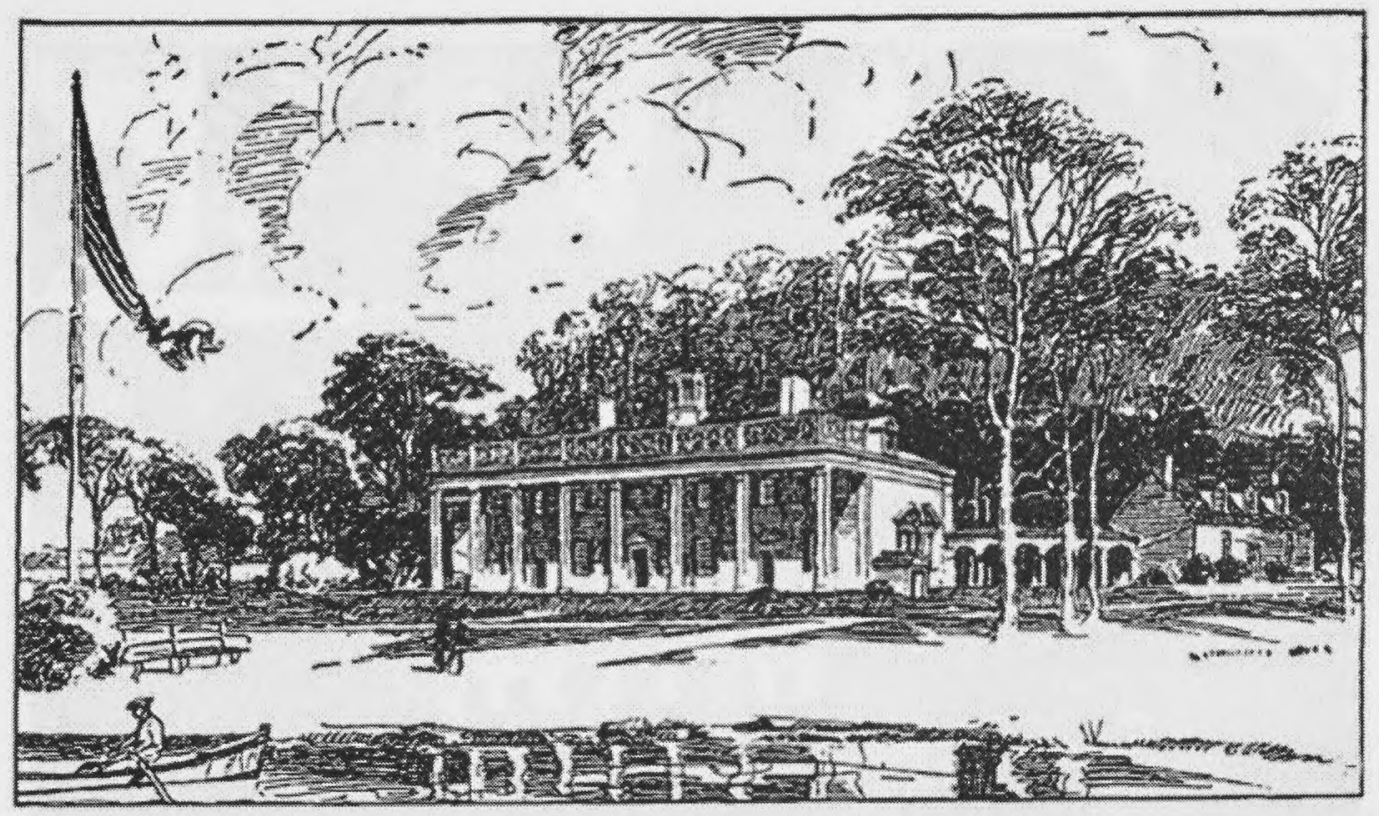

Figure 54. Bryant's rendering of the Prospect Park replica. 


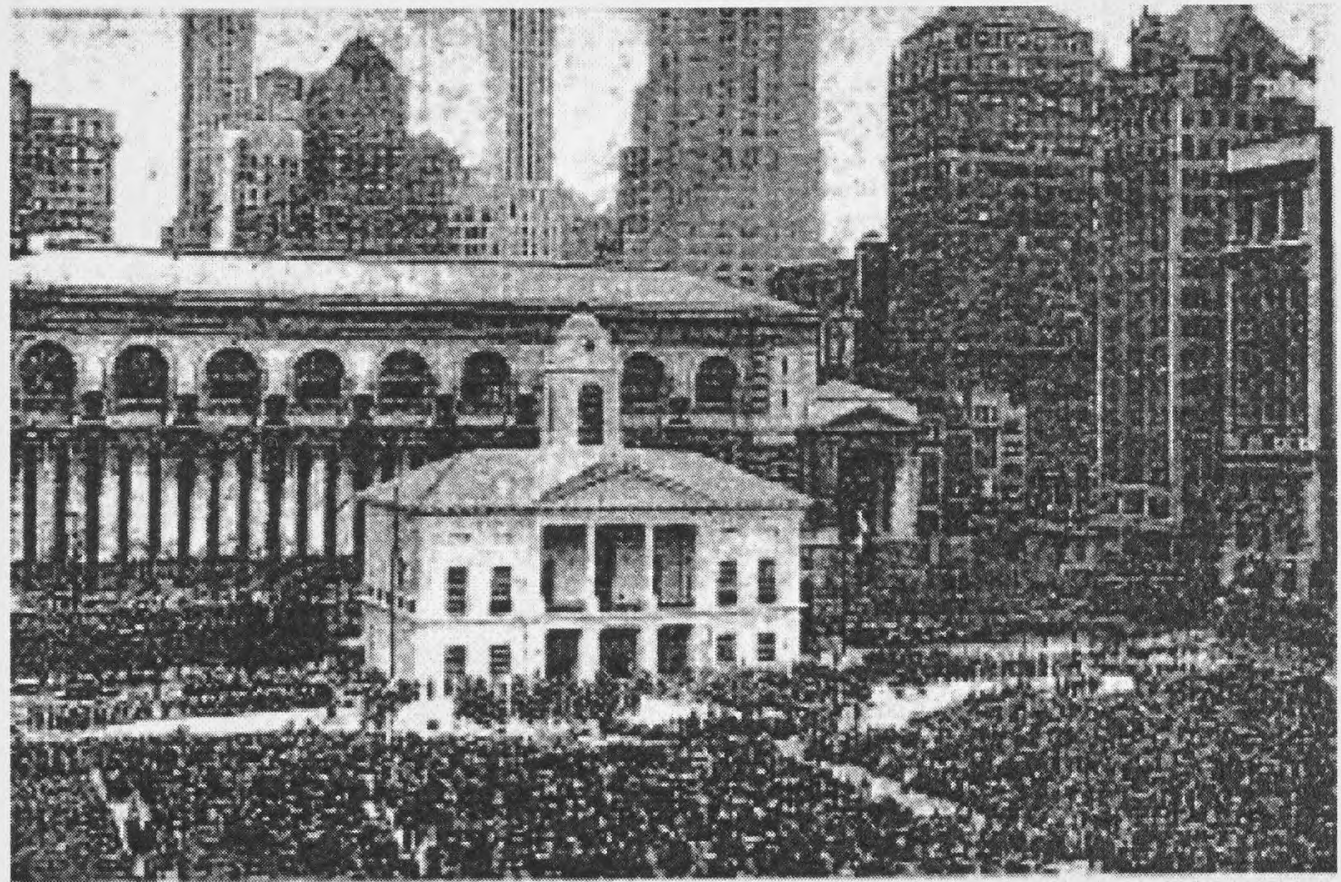

Figure 55. Federal Hall replica erected in Bryant Park, Manhattan, for the 1932 New York City Bicentennial celebration of Washington's birthday. The building was contracted by Sears, Roebuck and Company. 

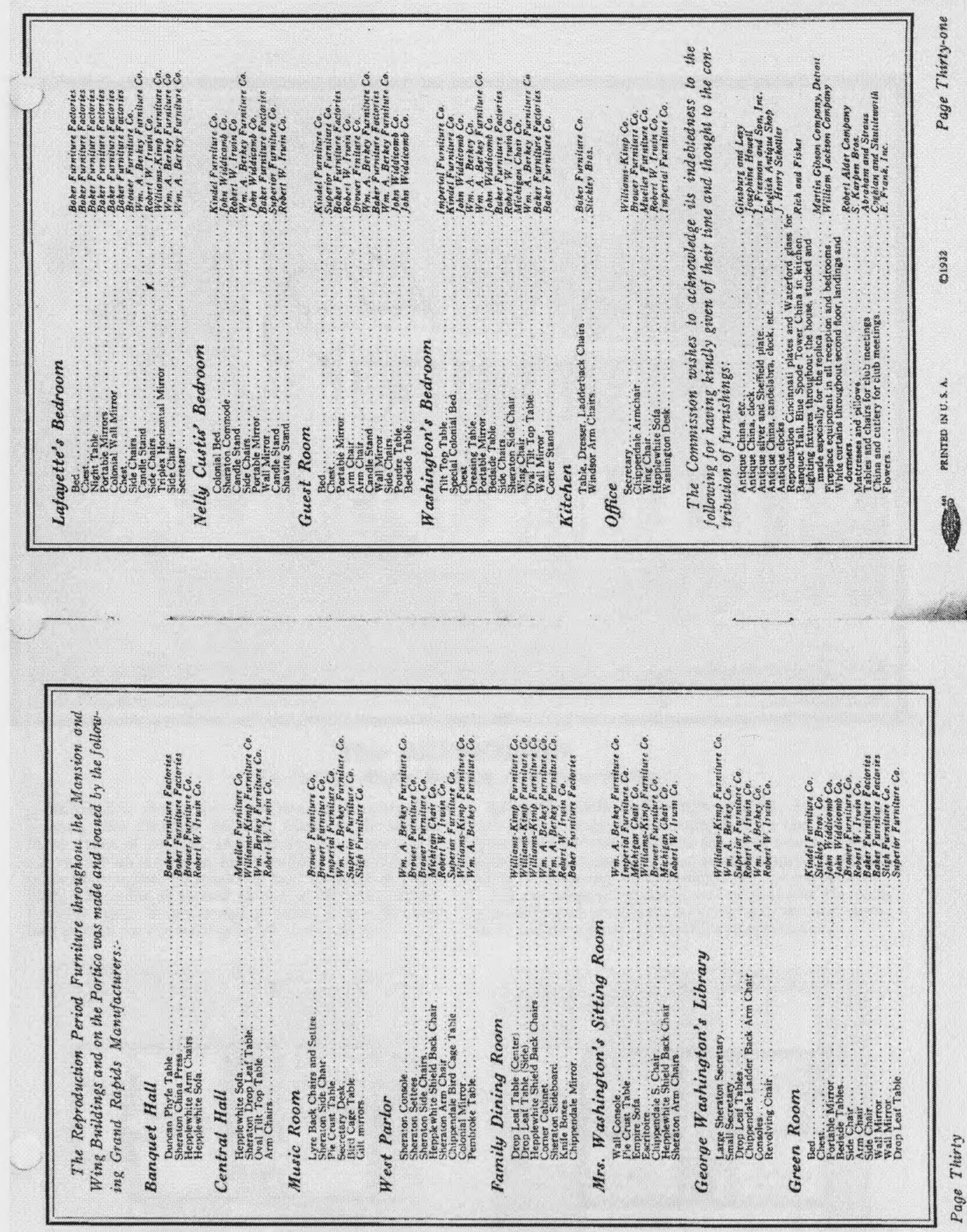

Figure 56. List of furniture in the 1932 replica by room. 


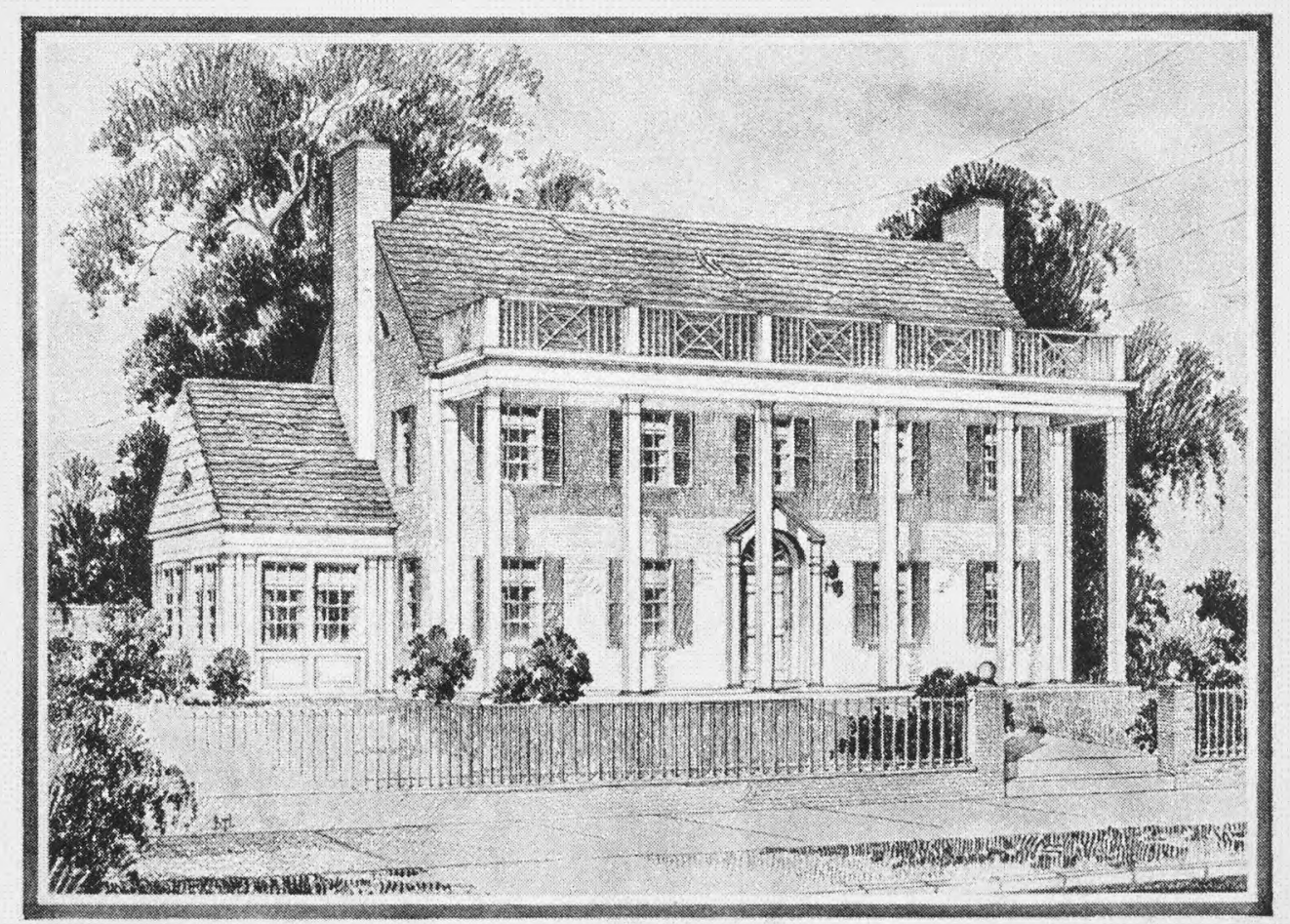

The IIFFFEIRSON

No. 31448-Wight Ttooms and Two Baths

DESIGNED along the same lines as historic Mt. Vernon, this southern colonial home spells success. Many types of colonial architecture have "stood up" for years with American home builders. Among these types the southern colonial has held its share of popularity and today is classed as one of the truest types. Exterior walls of whitewashed brick form a pleasing background for the dark green shutters and roof.

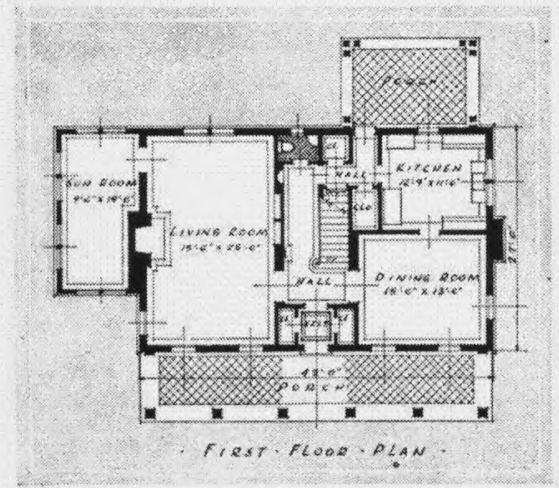

FIRST FLOOR PLAN

Page 30
LIVING ROOM AND SUN ROOM, dining room and kitchen open off the center hall on the first floor. Note many convenient closets for outer wraps. Second floor plan contains hall, four large bedrooms and two baths. This roomy home boasts a tutal of ten closets.

Fill out Information Blank and we will send you comFill out Information Blank and we will send you com-
plete delivered price, photographic architectural elevations and floor plans, also outline of specifications.

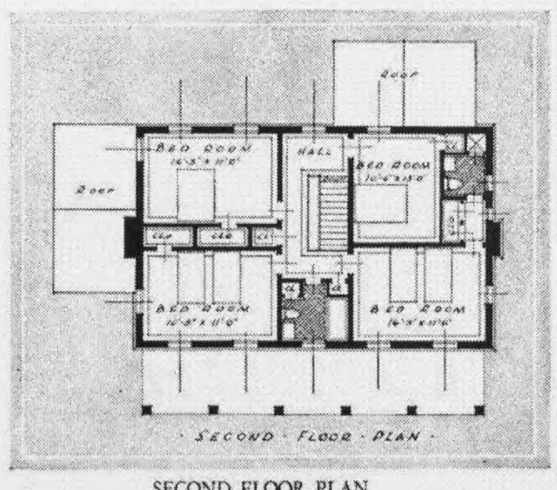

SECOND FLOOR PLAN

SEARS, ROEBUCK and CO.

Figure 57. "The Jefferson," sold by Sears, Roebuck and Company beginning in 1932. 


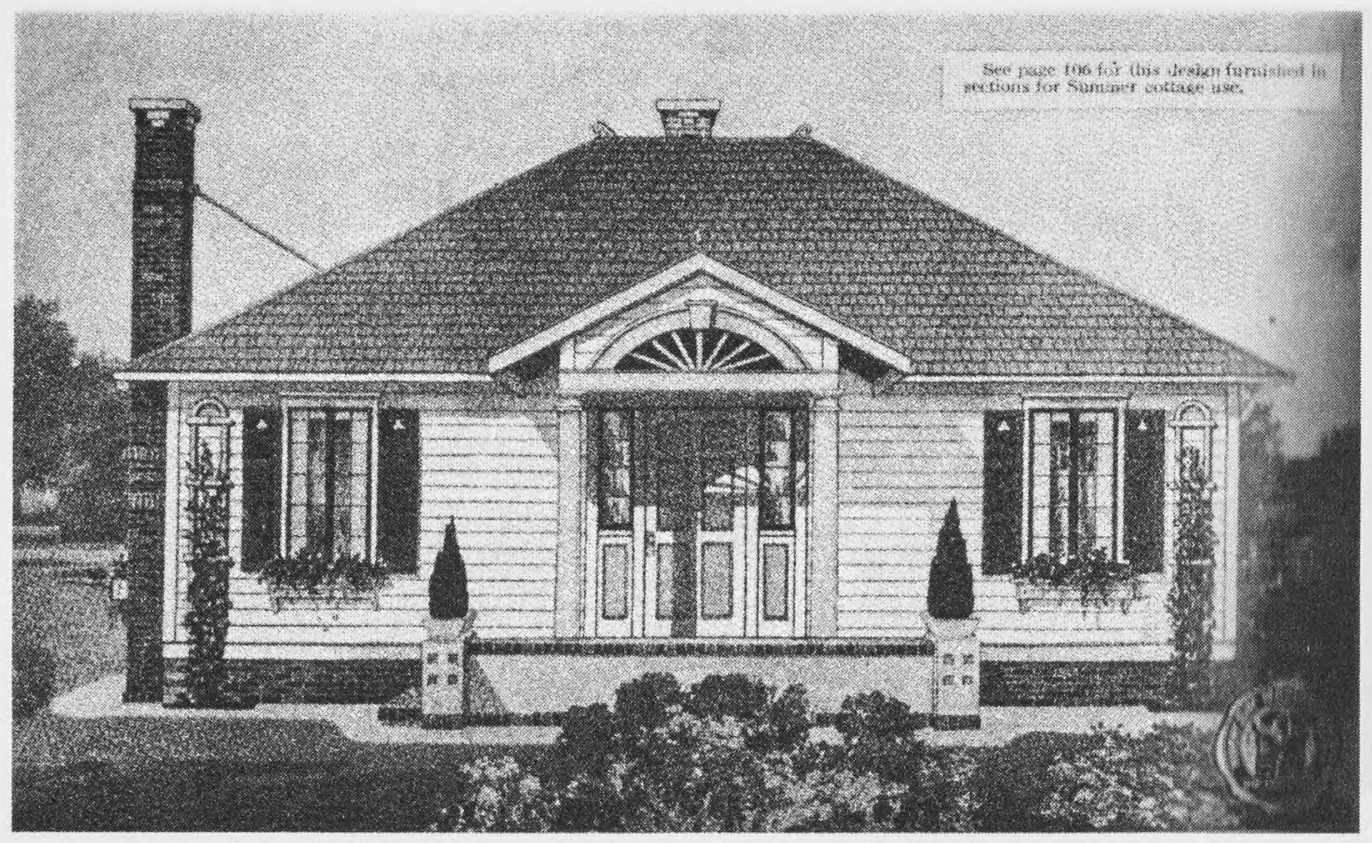

Figure 58. "The Mount Vernon," sold by Sears, Roebuck and Company beginning in 1921 . 


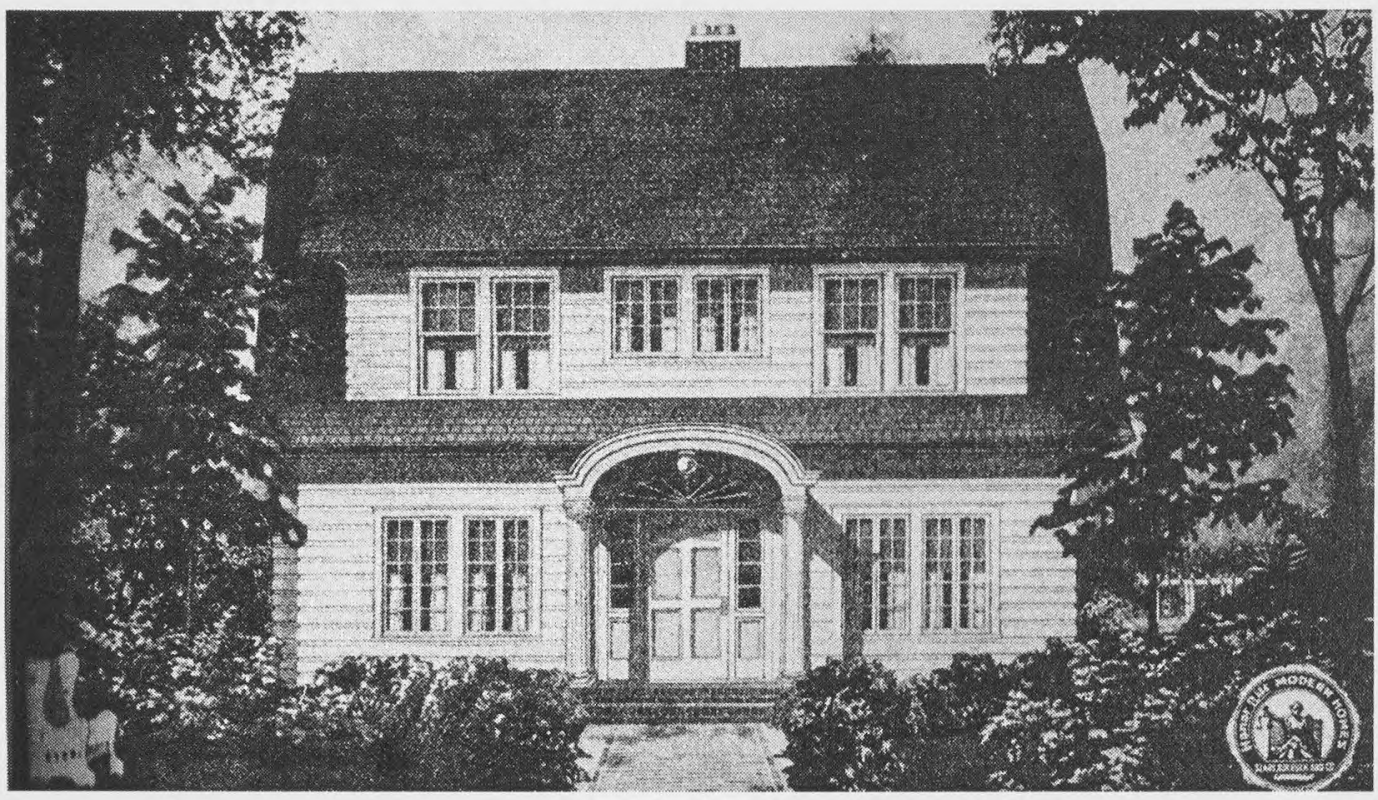

Figure 59. "The Martha Washington," sold by Sears, Roebuck and Company beginning in 1921. 